UNIVERSIDADE DE SAO PAULO FACULDADE DE FILOSOFIA, LETRAS E CIENCIAS HUMANAS DEPARTAMENTO DE GEOGRAFIA

\title{
O MENOR ENTRE A ESCOLA E O TRABALHO NA PERIFERIA PAULISTANA: \\ O Caso do Jardim Peri
}

\author{
CINYRA BALLASSINI
}

Dissertaçåo epresentade so Departamento de Geogrofla da faculdade de Filosolia, Letres e Ciencies Humanas de Universidede de Sio Paulo, pere obtençlo do titulo de Mestre.

Orientedoras Profe. Dre. Liliene Legeas. 


\section{INDICE}

PAG.

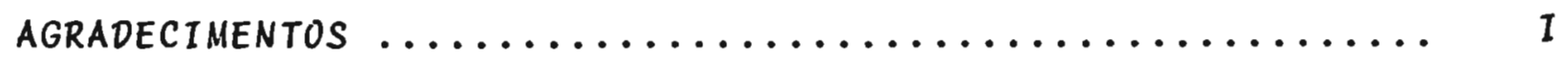

LISTA DE FIGURAS ....................... IV

LISTA DE TABELAS $\ldots \ldots \ldots \ldots \ldots \ldots \ldots \ldots \ldots \ldots \ldots \ldots \ldots$

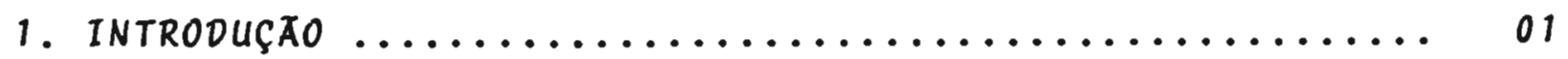

1.1. Consideraçöes preliminares ................. 01

1.2. Objetivos e hipōteses de trabalho .............. 09

1.3. Revisando a bibliografia sobre o menor........... 11.

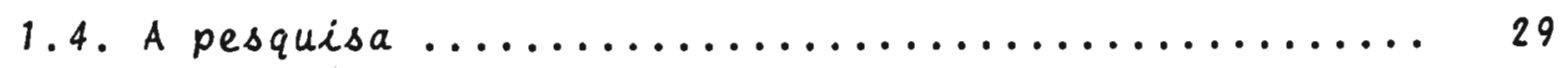

2. Metropolizaç⿸丆o, trabalho do menor e sua familia ...... 34

2.1. Metropolização de são Paulo ................. 34

2.2. O Jardim Peri na Metrōpole Paulistana .......... 38

2.3. O crescimento da população e a fundação das escolas 46

2.4. Caracterização do menor .....................66

2.5. Caracterizaçāo da familia .................69 69

2.6. Migração e trabalho ........................... 70

3. O trabalho e a escola ...................... 93

3.1. O trabalho e a legislaçäo .................. 93

3.2. O universo da pesquisa e propostas do trabalho..... 97

3.3. Análise dos dados obtidos no questionārio ........ 100

3.3.1. Relações de trabalho do aluno ........... 115

3.3.2. Jornada de trabalho e forma de pagamento.... 126

3.3.3. Esperança do progresso e necessidade de tra

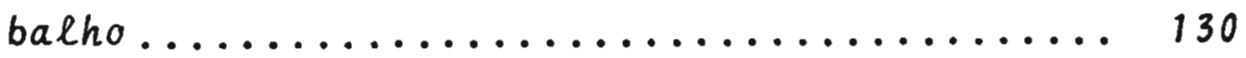


3.3.4. o trabalho e o rendimento escolar ........ 134

3.4. Relações aluno/escola/trabalho ............... 165

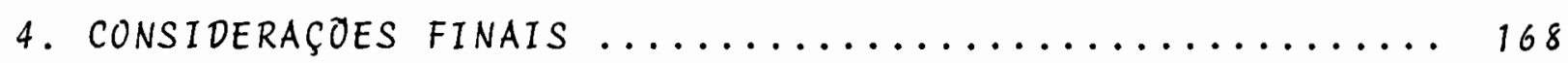

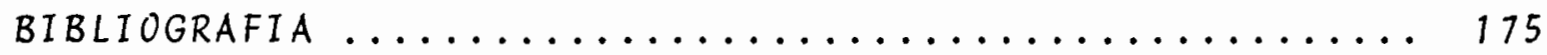

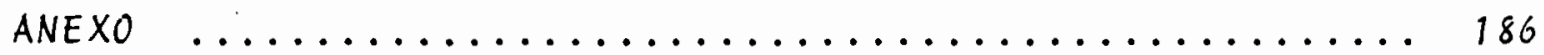




\title{
UNIVERSIDADE DE SÁO PAULO \\ FACULDADE DE FILOSOFIA, LETRAS E CIENCIAS HUMANAS \\ DEPARTAMENTO DE GEOGRAFIA
}

\author{
0 MENOR ENTRE A ESCOLA E O TRABALHO \\ NA PERIFERIA PAULISTANA: \\ 0 CASO DO JARDIM PERI
}

- CINYRA BALLASSINI

- Orientadora: Profa Dra Liliana Laganá

- Dissertação apresentada ao Departamento de Geografia da Faculdade de Filosofia, Letras e Ciēncias Humanas da Universida de de São Paulo, para obtenção do tîtu10 de Mestre.

São Paulo 1988 
A memōria de meus pais Jeronymo Ballas sini e Cornélia Luiza Demasi Ballassini que um dia foram menores trabalhadores; à Virginia Demasi Ballassini, minha tia, que com paciência me apoiou; aos meus irmãos Wilson e Amadeu Heitor pelo estí mulo oferecido; aos meus sobrinhos Anna Cristina, Wilson, Ricardo Heitor e $\mathrm{Pa}$ trícia de cāssia, pela ajuda prestada, $e$ aos alunos do Jardim Peri, pessoas que merecem meu profundo respeito e admiração, dedico este trabalho. 


\section{AGRADECIMENTOS}

O trabalho è uma tarefa pessoal, mas que só è poss $\underline{\text { i }}$ vel realizar com uma variedade muito grande de informações, con seguidas com a boa vontade de pessoas que sem interesse parti ciparam desta dissertação.

- A Profa. Dra. Liliana Laganá pelo voto de confiança ofereci do, mesmo naqueles momentos em que ficavam evidentes as mi nhas limitações; pela orientação segura e apoio em todos os instantes; pela paciēncia em rever várias vezes o trabalho a lém das valiosas crîticas e sugestões dadas, minha profunda gratidão;

- A colega Alice Yatiyo Asari pelo apoio e colaboração presta da na elaboração deste trabalho;

- Ao colega Milton Rodrigues dos Santos pelo estimulo e críti cas oferecidas no inīcio deste trabalho;

- A Faculdade de Filosofia, Letras e Ciēncias Humanas da USP;

- Aos companheiros dos colégios de pós-graduação da fFLCH da USP;

- A Profa. Anna Maria Marangoni pela orientação de grāficos e tabelas;

- Ao Prof. Mārio De Biasi pela orientação cartogrāfica;

- A Profa. e colega Nídia Nacib Pontuschka pelas sugestões a certadas;

- Aos diretores, professores e funcionārios das escolas que fá zem parte da pesquisa pelas informações fornecidas; 
- Ao engenheiro Carlos Eduardo Ferreira da Silva do Instituto Florestal do Estado de São Paulo pelo material fornecido;

- Aos funcionārios da Prefeitura de São Paulo, pelo fornecimen to de mapas sobre a ārea em estudo (SEMPLA - Regional da Fre guesia do 0 - Regional da Casa Verde);

- A 3a Delegacia de Ensino da Capital e a DRECAP I pelos mapas explicativos sobre as escolas em estudo;

- Aos alunos que responderam com paciência ao questionārio pa ra a elaboração deste trabalho;

- Ao colega Wellington Duarte que me acompanhou na pesquisa de campo fazendo levantamento dos alunos desistentes junto às favelas do Jardim Peri;

- A colega Profa. Rosa Maria Marchi Macedo pela colaboração e incentivo prestado no inicio deste trabalho;

- Aos colegas que colaboraram para o levantamento histōrico das escolas do Jardim Peri - Diva Therezinha Rosa, Dayse Bertoli, Ruth Trinca, Luiza Mantellassi, José Ademir Nardo, Etelvina Rissuthi Fernandes, Guiomar Cruz Antonio, Nilza Aparecida Bra ga, Maria Verônica da Silva, José Alberto Gonçalves;

- As colegas Beatriz Diniz e Darcy Aparecida Diniz pelo incentivo oferecido;

- A Maria Elisa C. Carvalho pela ajuda prestada;

- A Maria Thereza H. Fracalossi pela colaboração oferecida no meu exame de qualificação;

- Ao CNPq e CAPS pelo auxīlio financeiro oferecido; 
- As professoras Mabel Lūcia Moura e Analina Sartori pela revi são de portuguẽs efetuada;

- A Maria Aparecida Gallina que datilografou este trabalho e a todas as pessoas amigas que de alguma forma contribuiram pa ra que ele fosse executado.

MEUS SINCEROS AGRADECIMENTOS 


\section{LISTA DE FIGURAS E FOTOS}

FIGURA

PAG.

01 - Localização da Area de Estudo - Jardim Peri........ 39

02 - Limites da Area de Estudo .................. 41

03 - Localização da Area de Estudo (3 a DE-DRECAP-1)..... 45

04 - Evolução Urbana da Area de Estudo - Localização das

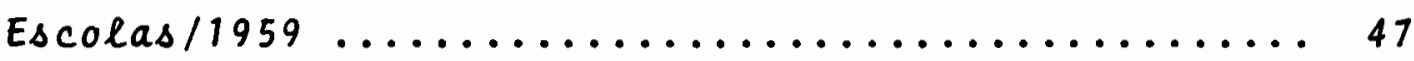

05 - Evolução Urbana da Area de Estudo - Localização das

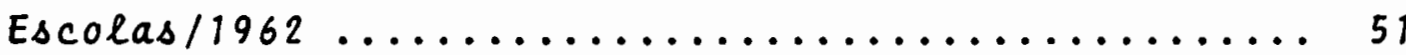

06 - Evolução Urbana da Area de Estudo - Localização das

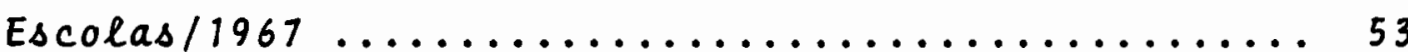

07 - Evolução Urbana da Area de Estudo - Localização das

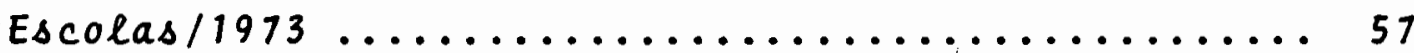

08 - Evolução Urbana da Area de Estudo - Localização das

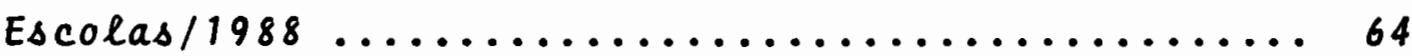

09 - De onde vieram para São Paulo Familiares e Alunos en trevistados .......................... 11

10 - Local de nascimento dos pais e avós dos entrevistá dos ................................. 74

11 - EEPG Proba Rita Bicudo Pereira - Profissão dos alunos por sexo $e$ idade ..................... 102

12 - EEPG Profa Elza Saraiva Monteiro - Profissão dos alu nos por sexo e idade ...................... 105

13 - EEPG Guilherme de Almeida - Profissão dos alunos por

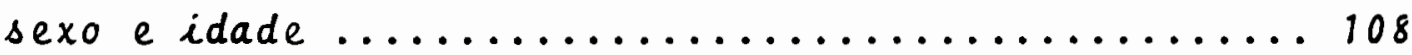

14 - EEPG Prof. Alfredo Gomes - Profissão dos alunos por

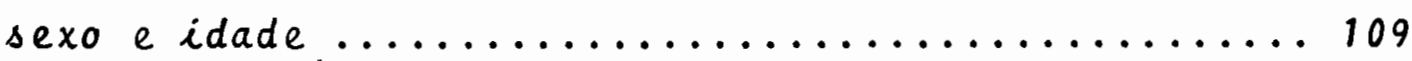


15 - Profissão dos alunos por sexo e idade - Todas as es-

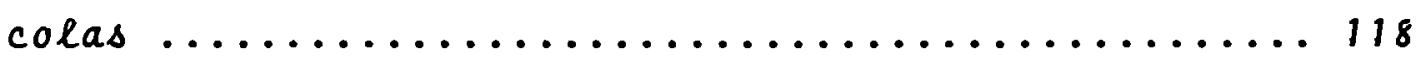

FOTO

PXG.

01 - EEPG Proba Rita Bicudo Pereira ............... 89

02 - EEPG Profá Rita Bicudo Pereira lalunos de curso no-

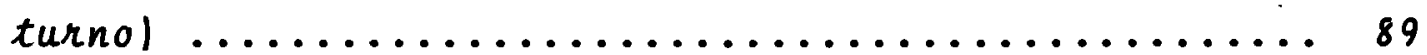

03 - EEPG Proba Elza Saraiva Monteiro ............... 90

04 - EEPG Profá Elza Saraiva Monteiro lalunos do curso no

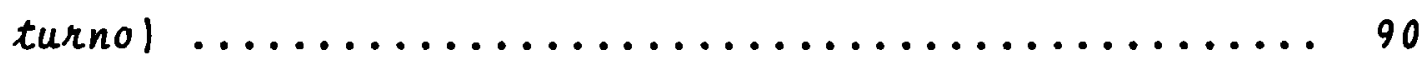

05 - EEPG Guilherme de Almeida .................. 91

06 - EEPG Guilherme de Almeida (alunos do curso noturnol. 91

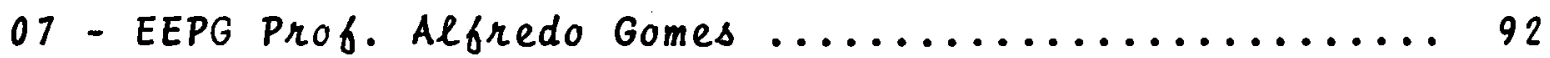

08 - EEPG Prof. Alfredo Gomes (alunos do curso noturno).. 92

09 - Vista Geral da Area de Pesquisa - Jardim Peri ..... 113

10 - Jardim Peri (habitações precārias) ............ 113 


\section{LISTA DE TABELAS}

TABELA

PAGG.

01 - Local de nascimento dos alunos .............. 76

02 - Total Geral por sērie - Escolaridade da famélia... 79

03 - EEPG Profa Rita Bicudo Pereira - Escolaridade da fa milia ........................... 80

04 - EEPG Profá Elza Saraiva Monteiro - Escolaridade da bamilia .......................... 81

05 - EEPG Guilherme de Almeida - Escolaridade da fami-

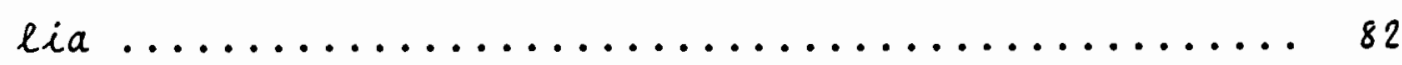

06 - EEPG Prof. Alfredo Gomes - Escolaridade da familia. 83

07 - Renda Mensal da familia dos entrevistados que in-

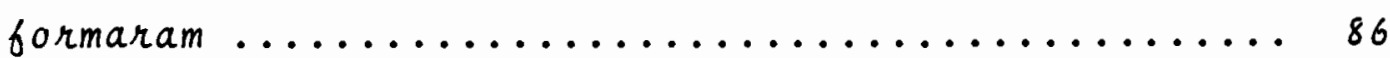

08 - Relação entre 0 no de pessoas que trabalham, no de pessoas da familia e total de familias .......... 87

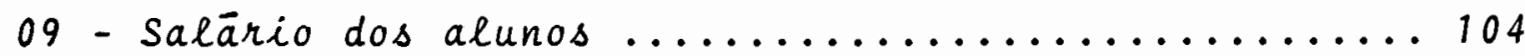

10 - Idade de ingresso dos alunos entrevistados, no mercado de trabalho .................... 116

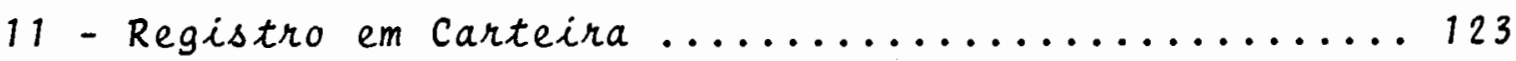

12 - Situação dos entrevistados quanto à contribuição no orçamento familiar ..................... 131

13 - EEPG Profa Rita Bicudo Pereira .............. 136 Rendimento escolar dos Alunos - $5 \underline{a}$ série

14 - EEPG - Profa Rita Bicudo Pereira ............. 138 Rendimento escolar dos Alunos - ba série

15 - EEPG Profa Rita Bicudo Pereira .............. 139 Rendimento escolar dos Alunos - $7 \underline{a}$ série 
16 - EEPG Profa Rita Bicudo Pereira ............... 140 Rendimento escolar dos Alunos - 8a sērie

17 - EEPG Profa Elza Saraiva Monteiro ............... 144 Rendimento escolar dos Alunos - $5 \underline{a}$ série

18 - EEPG Profa Elza Saraiva Monteiro .............. 145 Rendimento escolar dos Alunos - 6a série

19 - EEPG Profa Elza Saraiva Monteiro .............. 146 Rendimento escolar dos Alunos - $7 \underline{a}$ série

20 - EEPG Profá Elza Saraiva Monteiro .............. 147 Rendimento escolar dos Alunos - $8 \underline{a}$ sērie

21 - EEPG Guilherme de Almeida .................. 149 Rendimento escolar dos Alunos - $5 \underline{a}$ sērie

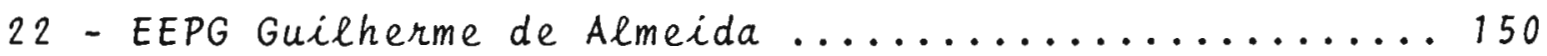
Rendimento escolar dos Alunos - 6a série

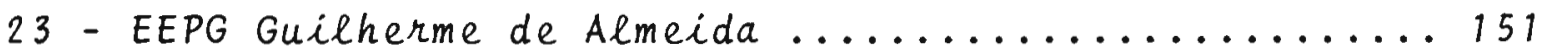
Rendimento escolar dos Alunos - 7a série

24 - EEPG Guilherme de Almeida ................. 152 Rendimento escolar dos Alunos - $8 \underline{a}$ série

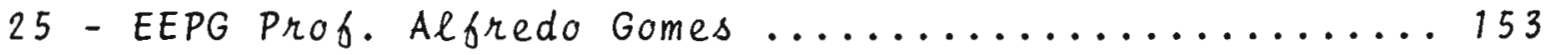
Rendimento escolar dos Alunos - $5 \underline{a}$ sērie

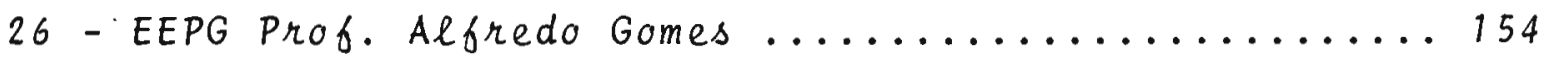
Rendimento escolar dos Alunos - 6a série

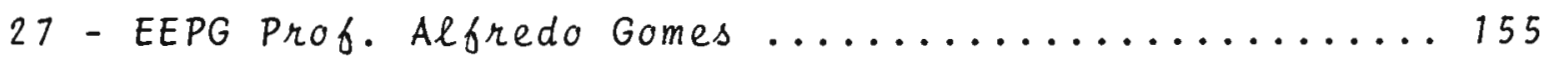
Rendimento escolar dos Alunos - $7 \underline{a}$ sērie

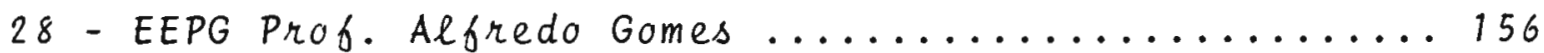
Rendimento escolar dos Alunos - $8 \underline{a}$ série 
"Não hă esperança da justiça social.

Por isso: só na luta se espera com esperança."

Paulo Freire 
CAPITULO I

INTRODUÇAO 


\section{INTRODUÇAO}

\subsection{Considerações preliminares}

Os enfoques iniciais deste estudo têm como referēncia as questões atinentes às transformações que estão ocorrendo no Brasil nas $\bar{u} l$ timas décadas, em consequéncia do acelerado proces so de industrialização pelo qual tem passado.

Os grandes centros sofreram rápida urbanização. Nos dias atuais o desenvolvimento capitalista constitui o elemento mais dināmico capaz de provocar profundas transformações sociais, pois o processo de mudanças abrange as mais variadas dimensões da vida social.

Em constatação mais ampla, para analisar a realidade da periferia urbana dos paises subdesenvolvidos, recorremos à história para mostrar como ela vem ocorrendo.

Essa urbanização se caracteriza por ser recente, ge ralmente posterior à $2 \underline{a}$ Guerra Mundial e por estar acontecendo em um ritmo bastante acelerado.

As diferenças entre os paỉses é notada embora eles a presentem caracteristicas comuns.

Milton Santos (1977:36), quando se refere à gênese dos dois sistemas de fluxo da economia urbana nos paises subdesenvol vidos menciona que

". pela primeira vez na histōria desses paises, va riāveis elaboradas no exterior têm uma difusão geral sobre toda ou sobre a maior parte do territōrio e a fetam todos os habitantes, embora em diferentes ni 
veis. A difusão da informação e de novas formas de consumo constituem dois dos maiores elementos da explicação geogräfica. Por intermédio de suas vā rias repercussões, elas geram, ao mesmo tempo, am bas as forças: a de concentração e de dispersão, cu ja interação define os modos de organização espa cial".

Ele menciona tambēm que

"... estas tendências de modernização contemporânea nos paises do terceiro Mundo, geram somente, um nü mero limitado de empregos, visto que as indústrias que estão sendo instaladas são de 'capital intensi vo'."

A população urbana cresce rapidamente, sem condições de acompanhamento por parte dos serviços, que atendem cada vez menos.

Milton Santos (1977:37) continua argumentando que

"... nas cidades dos paises subdesenvolvidos, o mer cado de trabalho estā se deteriorando, e uma alta porcentagem de pessoas não tem emprego nem renda. permanentes".

Vamos encontrar realidade semelhante a apontada por Milton Santos entre as famîlias que ocuparam os terrenos da pe riferia da cidade de São Paulo.

Para Manuel Castells (1983:84), a urbanização da Amẹ rica Latina enquanto processo social é definida por suas leis histōricas e que o espaço e a cidade fazem parte do processo de produção; sendo antes de tudo um produto da sociedade que a habita.

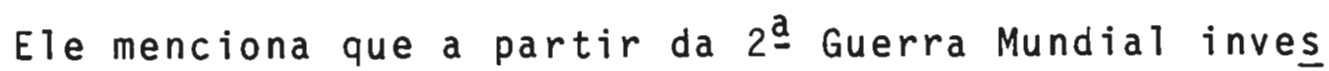


timentos estrangeiros são introduzidos no desenvolvimento de in dūstrias locais; as cidades transformam-se em centros industriais atraindo grande contingente populacional, sem ter condições de recebē-los e esclarece que:

\begin{abstract}
"A urbanização na América Latina não é a expressão de um processo de 'modernização', mas a manifestação a nivel das relaçöes sōcio-espaciais, da acentuação das contradições sociais inerentes a seu modo de desenvolvimento - desenvolvimento determinado por uma de pendência específica no interior do sistema capitá lista mundial".
\end{abstract}

Como no caso especīfico da periferia urbana da cidade de São Paulo cujo exemplo se refere ao Jardim Peri, setor da c $\underline{i}$ dade que abriga uma população que possui grande nūmero de migran tes que se dirigiram para a metrōpole paulista interessados em melhorar as condições de trabalho e de sobrevivēncia, o que nem sempre aconteceu.

Paul Singer (1980:117) ao analisar em seu trabalho o papel da urbanização no processo de desenvolvimento capitalista, em paises que tiveram industrialização tardia, estuda a problemática da cidade de São Paulo. Nesta anāise ele mostra a fun ção das grandes cidades em formar seu exērcito industrial de re serva.

Com a implantação na cidade de São Paulo do maior par que industrial do Paīs, a partir da 2 a Grande Guerra, a cidade se transformou no grande centro de interesse pela qualidade de empregos que oferecia, embora não fosse suficiente para a deman da; seu acelerado crescimento ocorreu e junto apareceram os de sequilibrios urbanos pela falta de habitação e serviços, cres- 
.04 .

cendo rapidamente a população marginalizada. Consequentemente surgem como alternativa de moradia os cortiços, as favelas, os loteamentos clandestinos, a exemplo do Jardim Peri.

Paul Singer (1980:119) coloca que para os criticos ur banos existem dois pontos de vista:

- económico, onde acreditam que a migração seja um processo de transformação dos produtivos trabalhadores do campo em subem pregados na cidade (engraxate, lavador de carro).

- social, onde os mesmos crïticos colocam que a desvinculação de integrantes de comunidades rurais, os tornam marginais na sociedade metropolitana.

".. a crîtica da urbanização tem como pressuposto bāsico de que não hā uma relação necessāria entre o crescimento da população e a expansão da economia da metrōpole". (1980:120).

Na mesma linha de constatação Lūcio Kowarick e Milton Campanārio (1986:1) apontam em seu trabalho que a cidade de São Paulo sede do "milagre brasileiro"

"...representa, de um lado, o centro nervoso de a cumulação do capital, onde as principais determinações macroestruturais da sociedade brasileira são forjadas. Por outro lado, a partir de 1960, a metrōpole constitui importante mediação no proces so de integração entre a economia do pais e o mer cado internacional. o espaço urbano forjado con centra não somente os meios de produção e de ge rência das grandes empresas multinacionais, estatais e privadas nacionais, mas também a força de trabalho que impulsiona a vasta e complexa engrenagem econômica instalada na região". 
Constatando os estudos de Kowarick e Campanārio te mos no Jardim Peri um dos inūmeros setores urbanos da metrópo le paulistana que foi produzido e ocupado por pessoas de con dições sōcio-econōmicas modestas que migraram para aquele lú gar a partir da década de 1960.

E importante salientar que o progresso econōmico da cidade acarretou o seu rápido crescimento deteriorando a qua lidade de vida da população.

A região metropolitana de São Paulo possui 15 mi1 hões de habitantes, conforme citação de Kowarick e Campanārio (1986:3), sendo a maioria constituida por assalariados mal re munerados, que moram em precārias condições, mal alimentados e que gastam muitas horas no transporte para o trabalho.

Kowarick e Campanārio comentam que na região mais rị ca do Paỉs o salário mīnimo decresceu em termos reais entre 1959 e 1984 mais de $55 \%$ e salientando que os contrastes entre o privilégio de poucos e a pobreza da maioria trabalhadora es tão visĩveis nas favelas da periferia.

No livro "São Paulo 1975, Crescimento e Pobreza " (1976:21), o intenso crescimento da cidade de São Paulo apare ce como sendo a lógica da desordem (1).

Na mesma linha de constatação eles colocam que o a mento rāpido da população da cidade torna visíveis seus pro blemas.

(1) Livro realizado por pesquisadores do CEBRAP - a pedido da Comissão de Justiça e Paz da Arquidiocese de São Paulo. 
o progresso dela tem um custo muito alto para a maio ria de seus habitantes, na medida que enfrentam carēncia no a bastecimento de āgua, insuficiência na rede de esgoto, eletrici dade, transportes coletivos, certos divertimentos pūblicos, ati vidades culturais, etc.

Na ideologia do progresso está implỉcito o sacrifício presente para se ter garantida a felicidade futura, embora es sas dificuldades sejam atribuidas ao crescimento desordenado da região metropolitana e à ausēncia de planejamento.

Esta situação pode ser constatada na forma de como $\underline{0}$ correu a ocupação do solo da cidade de São Paulo, no seu mapa a tual, cujo traçado irregular espelha vārios momentos histōricos de ocupação:

No livro "São Paulo 1975, "Crescimento e Pobreza" (1976: 22) :
"A aparente desordem do crescimento da cidade encobre, no entanto, a organizaçāo da sociedade. Por trās dos 'problemas urbanos' estā a vida dos habitantes da ci dade, que se organiza na repartição dos beneficios do desenvolvimento e na distribuiçāo do preço a pagar".

Na realidade, as condições de vida da população estão ligadas às formas de produção e distribuição da riqueza, como tambēm à divisão espacial de seus habitantes. Nas ūitimas dēca das surgiram na cidade de São Paulo os bairros periféricos que abrigam a classe trabalhadora.

\footnotetext{
"E nessas āreas que se encontram tanto a pobreza da cidade como a de seus habitantes". (1976:23)
} 
0 Jardim Peri è um dos inūmeros loteamentos da perife ria da cidade de São Paulo onde mora grande número de trabalhadores que fazem parte do processo produtivo industrial e comer cial da cidade.

Hoje 1988, a infra-estrutura e o saneamento bāsico a pesar de terem chegado naquele setor urbano não atingem toda po pulação, como também os transportes coletivos são insuficientes nas horas de pico, ocasionando um grande desgaste ao trabalhador além daquele despendido no trabalho.

Fazem parte do lugar vārias favelas, que abrigam famī lias cujo poder aquisitivo não proporciona moradia melhor.

Uma das propostas deste trabalho é tentar avaliar o rendimento escolar dos alunos do curso noturno daquele lugar e - envolvimento deles com a força produtiva da cidade de são Pau 10; e salientar a importāncia da escola para eles como também do trabalho; no que se refere à sociedade, até onde o mercado de trabalho necessita deles como mão-de-obra.

Meu interesse por este assunto remonta a 1972, quando fui lecionar na EEPG Profa. Rita Bicudo Pereira, que se localiza no Jardim Peri, na Zona Norte da Cidade de São Paulo.

Minha atividade docente no decorrer destes anos me proporcionou um relacionamento grande com uma clientela jovem e que faz parte de um grupo social de baixa renda. Nesse periodo tive oportunidade de observar as dificuldades que cs alunos en frentam para sobreviver, conciliando as obrigações do trabalho e da escola.

Através desta observação tive oportunidade de refletir 
.08 .

sobre a realidade dos meus alunos e me interessei em fazer um trabalho sobre eles.

As primeiras investigações foram efetuadas na EEPG Profa. Rita Bicudo Pereira, envolvendo alunos das primeiras até as oitavas séries, isto porque temos conhecimento que existe a lunos trabalhadores deste as primeiras séries.

0 levantamento efetuado atravēs de questionārio, em todas as classes e perīodos mostrou que o número dos alunos que trabalham até as quartas sēries é pouco significativo como tam bém são poucos no perỉodo diurno, mesmo entre as quintas e oi tavas sēries.

Este resultado me motivou a limitar minha investigação entre os alunos de quinta a oitava séries do periodo notur no, por existir entre eles grande número de trabalhadores; nes te momento do estudo achei importante ampliar o campo empírico incluindo a EEPG Profa. Elza Saraiva Monteiro porque ela está no mesmo setor urbano. O Jardim Peri possui só estas duas esco las de primeiro grau.

Numa nova fase do trabalho se tornou necessário am pliar mais uma vez a ārea de investigação com o intuito de ave riguar se a problemática vivida pelos alunos do Jardim Peri se repetia em escolas de setores vizinhos. A partir da $\bar{i}$ foram in cluĩdas tambēm a EEPG Guilherme de Almeida e a EEPG Prof. Al fredo Gomes que se localizam na Vila Amālia e Vila Bela Vista, respectivamente. 


\subsection{Objetivos e hipöteses do trabalho}

Os objetivos propostos para a elaboração deste traba Tho apresentam très nỉveis de abordagem:

Como nosso primeiro objetivo é estudar ao mesmo tem po estudo/trabalho em relação aos alunos do curso noturno das quatro escolas envolvidas na anālise e suas consequéncias; op tamos pela pesquisa do universo das escolas e o depoimento dos alunos.

No àmbito desse trabalho deixamos de analisar o uni verso do trabalho (pesquisa junto aos empregadores e observação no trabalho) porque seria necessārio a realização de um outro trabalho. No entanto, através dos alunos pudemos ter informações sobre o prōprio trabalho deles e a visão que tēm sobre a atividade que exercem.

Em decorrēncia das transformações que vēm ocorrendo em nosso Paỉs e que levam à grande concentração de renda a uma minoria da população, inúmeros estudantes menores que fazem par té das famīlias de baixa renda tēm necessidade de participar do processo produtivo para garantirem sua sobrevivēncia. Pretende mos averiguar seu indice de participação no mercado de trabaTho, em que condições isto vêm ocorrendo, os objetivos pretendidos pelo menor estudante como tambēm as consequéncias que eles vēm sofrendo tanto no aproveitamento escolar quanto no tra balho.

O segundo objetivo tem por meta investigar a importān cia do trabalho do menor para o processo produtivo. A anālise do universo trabalho foi efetuada a partir da interpretação das 
respostas fornecidas pelos questionários e, principalmente, por observações efetuadas nas entrevistas nos domicilios dos alu nos.

Procurou-se atravēs de informações fornecidas pelos alunos nos questionārios identificar a conduta do empregador no cumprimento das leis de proteção ao menor.

o outro objetivo diz respeito à constatação da neces sidade do trabalho do menor para complementar a renda familiar.

Foram tambēm objeto de anālise a famîlia, grupos sọ ciais de que fazem parte, os motivos que originaram a migração, fixação e urbanização do Jardim Peri, que se constituiram em Elementos explicativos da problemātica estudada.

De outra maneira, a elaboração de um trabalho pressú põe a tomada de algumas posições que auxiliam o seu trajeto den tro de uma coerência e de uma reflexão maior do problema em es tudo. Algumas hipōteses foram levantadas, tendo em vista o te ma geral, relações existentes entre a escola e o trabalho, cons tatando-se o baixo rendimento escolar no decorrer do ano leti vo imposto pelas pequenas possibilidades de tempo que esta clien tela possui para estudar.

Outra hipótese coloca-se como consequência do pequeno aproveitamento surgindo o desestímulo e em seguida temos co mo resultado a desistência da frequência às aulas.

A hipótese seguinte diz respeito ao pressuposto mais acentuado de se encontrar o trabalhador entre os alunos de 5 a a 8 a séries do curso noturno cujo horārio está relacionado com suas necessidades de trabalho. 


\subsection{Revisando a bibliografia sobre o menor}

O trabalho do menor constitui um assunto que possui dimensões significativas para anāilise e reflexões na realidade da sociedade brasileira.

Apesar de sua importância ele tem sido pouco abordado e percebe-se que os āngulos de anālise em nossa sociedade têm seguido outras direções.

Todas as questões são relevantes quando estão ligadas ao menor, porém o assunto trabalho do menor que envolve um ema ranhado de relações e que apresentam variadas condições de rea lização acaba sendo esquecida, alēm de existir fatores extrema mente complexos de dificil abordagem por envolver interesses tanto do lado do empregador que almeja pagar o salário mais baixo possivel, como do lado do menor e de sua famīlia que ne cessitam do emprego.

Como nos mostra Lia Fukui, Efigênia M.S. Sampaio e Lucila R. Brioschi no estudo que fizeram sobre o trabalho in fantil atravēs da abordagem da grande imprensa paulista.

As autoras colocam que a valorização da escrita e da leitura em nossa sociedade contribui para que grande parte de nossos menores cujas condições de vida são precārias, tentem associar o trabalho e a frequència à escola.

A realidade mostra os aspectos conflitantes em que vivem nossas crianças

".. a participação em uma sociedade letrada exige, para a sua prōpria sobrevivência, a aquisição das habilidades da leitura, da escrita e do cālculo. Se, para segmentos privilegiados a escola $\bar{e}$ uma $\underline{a}$ 
quisição antiga, para os segmentos subalternos ela ainda $\bar{e}$ objeto de reivindicação." (1984:2)

Torna-se necessārio uma discussão a respeito, cuja realidade a escola deve considerar, se o seu objetivo for ens $\underline{i}$ nar e não discriminar.

Com uma proposta de se repensar o problema em debate Fulkui, Sampaio e Brioschi se propuseram a analisar o discurso que põe em relação a desescolarização, o trabalho infantil e o problema do menor, através da grande imprensa paulista.

Foram tomados trēs jornais de grande tiragem e ampla circulação em São Paulo - O Estado de São Paulo, a Folha de São Paulo e Noticias Populares em dois períodos distintos - 1971 , 1972, 1973 e 1978, 1979, 1980 selecionando e analisando a for ma da abordagem do assunto.

Constataram que dos trēs temas o trabalho infantị foi o menos divulgado, independente do periodo e do jornal; con cluiram que hā uma ocultação por parte da imprensa, desse trá bal hador.

Relatam que ao abordar o tema, as fontes de documentação utilizada são, predominantemente, as oficiais.

Quanto ao conteūdo da matéria os três jornais colocam que:

- reconhecem a existência do trabalho infantil e desconhessem sua extensão;

- aprovam o trabalho institucionalizado;

- discutem a redução do salārio do menor embora seja assunto con trovertido, porque essa inserção formal no mercado de traba- 
Tho concorre com a mão-de-obra adulta.

Os jornais colocam como problema a falta de dados so bre a extensão do trabalho infantil principalmente quando se trata de trabalho formal; o argumento que persiste è a necessidade de manter de alguma forma o controle sobre esse segmento da população.

Ficou claro que as noticias nunca exploram as circuns tāncias a que a populaçaõ infantil está sujeita, obrigada a tra balhar pela sobrevivēncia e impedida de frequentar a escola por le $\mathrm{i}$

"... A grande imprensa, pois, apresenta o trabalho in bantil como necessārio para a prevenção da delinqllên cia, usando argumentos baseados na habilitação e ca pacitação profissional, sem levantar para o debate os aspectos de exploração a ele associados" 11984:28 e 291

Em trabalho anterior sobre os excluidos da escola, Fulkui, Sampaio e Brioschi,estudam a escola elementar, comiènfa se nas relações sociais que caracterizam o sistema escolar como àrea específica da vida social.

Nesta pesquisa elas se dedicam em estudar escola/trabalho pretendendo mostrar a educação sendo limitada pelo traba1ho, na qual a escolarização do menor está presa ao trabalho; e traçam um paralelo entre - a exclusão da escola e a ausencia de procura educacional - que definem como sendo a necessidade do trabalho além de outros fatores.

Foi apontado como

".. caracteristica essencial do sistema escolar bra sileiro uma ineficiēncia básica, uma vez que, nāo 
conseguindo abarcar a totalidade da população esco larizāvel, produz excluídos da escola ao mesmo tem po que cria mecanismos de reciclagem para minimizar a extensão dessa ineficiência no conjunto da população" (supletivo) (1981:4).

0 primeiro levantamento dessa pesquisa contou com da dos da Secretaria da Educação. 0 segundo ocorreu com dados obtidos em àrea rural e urbana. O terceiro foi efetuado depois de caracterizados o sistema escolar e a clientela.

Após ampla análise e reflexão Fukui, Sampaio e Brios chi concluiram que

"... A seletividade estā presente de maneira explícita dentro do sistema escolar e contribui desta for ma de maneira clara para os indices de repetência, abandono e exclusão da clientela escolar" (1981:8)

Colocam ainda que a escola de primeiro grau brasile ra tal como se apresenta, dirige-se a uma clientela que não ne cessita trabalhar.

Alvim coloca em discussão o comportamento na forma de dominação prōpria às fábricas com Vila operāria (descrito em 1979 pela primeira vez).

A maior parte dos entrevistados passaram por um pro cesso de proletarização a partir dos anos 30 deste sēculo.

A absorção de mão-de-obra para indūstria tēxtil, em Pernambuco, era efetuada através de aliciamento junto a grupos sociais camponeses ou de pescadores.

Eles tinham como interesse principal familias numero sas, cujo peso maior nesse tipo de contrato recai sobreas crian 
ças e jovens.

Pessoas isoladas se agregavam à famỉias para poderem trabalhar; esse processo interessava ao aliciador e à famīlia.

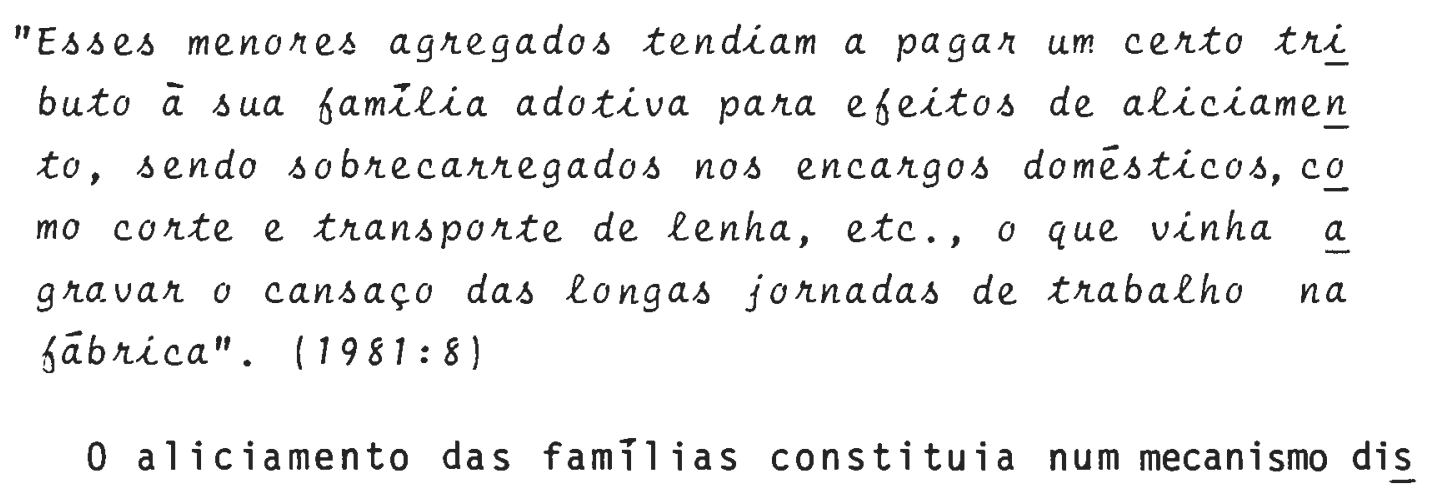
farçado para recrutamento de crianças e jovens; e isto era feito onde a crise de reprodução das familias era mais grave.

0 desempenho dos pais correspondia a serviços periféricos como cata do algodão no início do processo produtivo. Foi apontado também que o nūmero de quartos da casa estava relacionado com o nümero de operārios que trabalhavam na indústria.

\footnotetext{
"Com isto a fábrica cria todo um sistema de estímulo para que as familias enviem um maior nümero de trabalhadores para suas dependências industriais, for çando por assim dizer a continuidade de uma mão-deobra fixa". (1981:10)
}

Era comum a direção da fābrica incentivar as famīlias na alteração da idade de seus filhos para que mais cedo pudessem participar do processo produtivo.

"O trabalho das crianças significava para a fäbrica a formação de profissionais para os diversos serviços necessārios na indüstria têxtil" 11983:131

Alvim, teve nessa demonstração intenção de avaliar o significado do trabalho infantil em uma fábrica com vila operária. 
Referindo-se ao trabalho infantil na agricultura em processo de mudança, nas relações de trabalho Antuniassi teve por objetivo investigar a existēncia e a consequéncia social dessa participação,

"... tendo em vista o processo de escolarização".

$(1983: 15)$

Atravēs de um estudo sobre agricultura no Estado de São Paulo, ela utiliza dados levantados pelo Instituto de Economia Agrícola de São Paulo que mostra a evolução da participa ção da mão-de-obra infanto-juvenil na força de trabalho agrỉco la, no perỉodo de 1970 a 1975. Ela mostra que é na década de 70 que ele começa a aparecer com mais frequéncia, quando é observado o processo de proletarização do trabalhador rural, expansão do trabalho assalariado, principalmente, o volante.

Constata que o trabalhador mirim não è dispensado em nenhuma das categoriais de trabalho embora sua participação se ja mais intensa na unidade familiar.

Antuniassi tambēm observou que

"... a criança trabalha sem remuneração, mesmo quan do o pai ou responsāvel è um trabalhador". 11983: 1041

Acrescenta que são as pequenas propriedades que mais empregam a mão-de-obra infantil, tanto nas categorias que tra balham por unidade familiar quanto entre os assalariados e que a participação do trabalhador-mirim do sexo masculino é maior.

Quando estabelece a relação entre trabalho infantil e produtos cultivados, separados segundo niveis de tecnificaçãotradicionais, em transição e modernos, segundo as regiões onde 
predominam, verifica que a população trabalhadora infanto-juve nil se distribui de forma desigual. Nas regiões em que predomi nam os produtos considerados em transição e tradicionais a par ticipação maior é do trabalhador mirim proprietārio, enquanto as āreas mais modernas, com maior área cultivada a agricultura tecnificada a participação maior é do trabalhador mirim volante.

Esta diferenciação segundo a autora revela que o em prego deste tipo de mão-de-obra está associado à modernização parcial da agricultura como tambēm

"... os dados mostram que proporcionalmente são as propriedades menores $(a t \bar{e} 100 \mathrm{ha})$, as que mais uti lizam mão-de-obra temporāria mirim como estratégia para rebaixar os custos relativos $\bar{a}$ força de traba lho" (1983:107).

E importante mostrar que

"... o nümero de trabalhadores volantes mirins cres ceu 6,5\% no período de 1970-75 enquanto a mão-de-o bra volante adulta diminuiu na mesma proporção" $(1983: 106)$

Com relação ao trabalho infantil/escolarização

"... mostram que, entre os alunos das escolas pesquisadas pelo CERU (2), o nūmero dos trabalhadores aumenta com a idade. Aos 12 anos, 50\% das crianças estão conciliando as tarefas escolares com o traba lho. Observamos que o trabalho estā negativamente associado ao sucesso na vida escolar".

(2) CERU - Centro de Estudos Rurais e Urbanos. 
"A liberação das crianças do trabalho familiar depen deria de uma modernização mais abrangente que se bi zesse acompanhar de uma modificação na estrutura de posse e uso da terra, capaz de assegurar ao trabalha dor familiar maior participação no valor produzido". (1983:113).

o problema apresentado deve ser refletido, uma vez que a autora afirma o fator negativo do alto indice de repetencia e evasão escolar com a população entrevistada, este fato confirma - papel negativo do inỉcio muito cedo na atividade produtiva.

0 trabalho de Cheywa R. Spindel tem por finalidade es pecial estudar o menor trabalhador assalariado registrado.

Esta pesquisa foi realizada emi 8 Estados Brasileiros, abrangendo as regiões Nordeste, Sudeste e Sul, com 1.000 meno$r \in s$ empregados em indústria e no comércio; foram entrevistados 120 empresārios.

A preocupação bāsica è saber quem são os menores, por que trabalham, qual o segmento social que os produz e quais as suas habilidades e aptidões valorizadas no mercado.

Através de dados estatísticos do censo de 1980 Spindel coloca

"... verificamos que para cada trabalhador menor registra do hã 10 que não o são" (1983:1)

Participaram das indagações a famîlia, escola e a em presa, trabalhadas articuladamente.

A autora observa que

"... a evolução crescente na 'oficialização' de menores no mercado de trabalho urbano, e sobretudo na in dūstria, no período de 1970-1980, no Brasil, pari pas su ao crescente aumento da composição orgânica do ca 
pital industrial pode ser um jato amais na argumenta ção de tese de 'desvinculação' do capital da escola. No entanto não se deve esquecer que, não só a estrutura rigida e centralizada do sistema educacio nal, ainda estā sintonizada ao binômio educação produtividade como tambēm ainda permanecem em pé os valores familiares que se apoiam na crença da correlação direta entre produtividade e salārios" $(1983: 4-5)$

Ao problematizar o trabalho do menor ela revela que os empregados registrados conseguiram esta situação atravēs de informações fornecidas pelos prōprios empregados, cabe ressal tar que $60 \%$ dos entrevistados pertencem a familias de chefes, funcionārios com ocupação qualificada ou semi-qualificada; o que revela melhor nível sócio-econômico de que faz parte o me nor registrado, no interior da classe trabalhadora.

As grandes e médias empresas apontaram escolaridade como triagem para ser admitido no emprego, embora a maior preo cupação do empresārio não esteja no conhecimento obtido no sis tema de ensino mas ligado ao processo de socialização do menor; ou seja, obediēncia e certos padrões de comportamento que per mitem ao empregador mais segurança frente às condições de disciplina e de trabalho impostas.

A experiência de trabalho foi bastante mencionada nas pequenas e médias empresas na seleção dos menores e aparece bas tante valorizada à frática doméstica. Com o intuito de aproximação da realidade foi perguntado aos entrevistados porque es tavam trabalhando. As respostas obtidas mostraram que apenas 1 em cada 2,5 deste grupo de trabalhadores participavam do proces so produtivo por necessidade. Do total de menores estudados $1 / 5$ 
tem acesso integral ao produto do seu trabalho; a maioria entre ga parte à famīlia; na região Sul/Sudeste, $14 \%$ deles entregam 0 envelope fechado em casa; o comportamento adotado está diretamente ligado aos padrões de comportamento da familia.

Este trabalho comprova que a idade e o sexo tambēm con tribuem para controlar a posse ou não do salārio e as meninas são mais penalizadas em relação aos meninos; o compromisso de trabalho é igual para meninos e meninas mas não a contribuição a ser paga à famīlia. Spindel coloca

"... para uma parcela importante dos menores que tra balham, o trabalho $\bar{e}$ a maneira encontrada para man ter um nivel de reprodução social que acompanha, a evolução do nivel das forças produtivas, ou pelo me nos que permite não ampliar a defasagem historicamen te existente". (1983:20)

Foi constatado neste estudo que o trabalho é um obstā culo a uma trajetória educacional mais prolongada, contudo as estatisticas da ūltima década indicam um aumento no nível dos menores que trabalham como tambēm o número daqueles que trabaTham e estudam.

Hoje a escola não é prioridade primeira para aqueles que têm menor poder aquisitivo. Convém mostrar, como única exce ção, os trabalhadores das indústrias metalürgicas, que, embora submetidos a longas jornadas de trabalho e a condições insalu bres, conseguem conciliar escola e trabalho.

Gouveia faz uma anālise junto a algumas escolas notur nas e vārios locais de trabalho das cidades de São Paulo e San to André. Investigou-se como se dá a contratação dos menores, a forma como eles encaram a situação aceitando trabalhar em condi 
.21 .

ções pouco vantajosas com o intuito de conservar o emprego.

Ficou claro a consciência que eles possuem a respeito de certas atividades que não oferecem ascensão profissional, que eles encaram com resignação. A pesquisadora deixa evidente que este trabalho ocorre por necessidade da familia. Para o menor trabalhar, levar dinheiro para casa dä "status", ele se sente realizado, fato pelo qual Gouveia (1983:61) o interpreta como "necessidade transfigurada em virtude" indicando de forma apropriada o efeito da socialização ou ideologização.

Carvalho demonstra em seu trabalho sua constante preo cupação com o ensino noturno no Brasil, ela questiona a qualida de de conteūdo que é transmitida para os alunos que tem necess $\underline{j}$ dade de trabalhar durante o dia. Ressalta o importante papel da escola como transmissora de conhecimento e faz criticas frente às contradições que existem em seu interior; suas propostas são aparentemente igualitārias embora ela participe ao mesmo tempo da formação do trabalhador e do empregador.

Sua pesquisa ocorreu no interior de uma escola em $R \underline{i}$ beirão Preto - São Paulo, onde atravēs de entrevistas, apli cação de questionārios efetuada com alunos, e funcionārios ela teve $\underline{0}$ portunidade de constatar que na escola:

$$
\begin{aligned}
& \text { ".. se configuram duas situações bem diversas e ex } \\
& \text { pressam a divisão em classes sociais que se repro- } \\
& \text { duz no interior do ambiente escolar" (1986:35) }
\end{aligned}
$$

na medida em que professores e alunos 1 he revelaram que o ensino é reduzido, ocasionado pela falta de condições dos alunos a prenderem depois de uma jornada de trabalho de 8 horas ou mais e que a situação dos professores é semelhante. 
Como se vē, tudo contribui para que o aproveitamento do noturno seja menor. Mesmo assim os alunos procuram frequentá -10, pelo papel ideológico que exerce, na medida que atribui ao conhecimento que a escola transmite, como sendo única forma de melhorar socialmente.

Carvalho ressalta que o ensino noturno surgiu para $\underline{a}$ tender os alunos que estão envolvidos no mercado de trabalho e que

"... a escola situa-se como instituição que contribui para a reprodução do trabalhador à medida que prepara a força de trabalho para ser 'livre', ofertante no mundo da mercadoria" (1986:17)

A autora demonstra que alunos e professores concordam com ensino fraco e reduzido transmitido na escola noturna, o que eles não entendem claramente é que isto ocorre por motivos que extrapolam ao funcionamento da escola.

Carvalho coloca as razões da existēncia destes cursos que precisam ser procurados fora da escola, uma vez que os al nos fazem parte de familias trabalhadoras e o seu trabalho é im portante para a reprodução social da própria famỉlia.

"E o prōprio conceito de trabalho que precisa ser reformulado". (1981:170) (tese)

Faz-se necessārio colocar as observações de alguns e ducadores:

A Profa. Bittencourt (1986:1) em seu trabalho ao re fletir sobre a Histōria da Educação no Brasil nos mostra que a Geografia e a Histōria, como disciplinas escolares tiveram papel interligado no currículo, pelo menos no que se refere à temáti- 
ca brasileira.

Com as atuais mudanças politicas surge a necessidade de se adequar o currículo à nova realidade politica e social; pois é atravēs delas que o ensino e a aprendizagem se efetuam, na prātica do cotidiano.

"O curriculo é a via pelo qual se pode concretizar - caminho percorrido pela escola. Nessa dimensão ele pode se tornar agente de transformação no com portamento educacional; pode ser a forma de se ar ticular o processo democrātico através da relação probessor-aluno".

A autora coloca que devemos pensar em outra escola, em vista de que a geração de alunos e professores é outra; cer cada de novos meios de comunicação, num mundo que a escrita se coloca de outra forma.

Torna-se necessārio:

"... refletir sobre a preocupação de um curriculo que proporcione uma participação democrātica do a luno e que realmente esteja voltada para as camadas populares". (1986:7)

As observações efetuadas por Paulo Freire no decorrer de sua experiência com educação de adultos nos mostra a necessidade de se organizar programas com vocabutārio vindo do uni verso dos grupos populares, que expresse a sua real linguagem, os seus anseios, as suas inquietações, as suas reivindicaçöes, os seus sonhos. Ele mostra:

"... se, do ponto de vista critico, não $\bar{e}$ possivel pensar sequer a educação sem que se pense a ques ião do poder; se não $\bar{e}$ possivel compreender a edu cação como prātica autônoma ou neutra, isto não 
significa, de modo algum, que a educação sistemāti ca seja uma pura reprodutora da ideologia dominante" (1984:28)

uma vez que
"... a negação daquela ideologia lou o seu desvela- mentol pela confrontação entre ela e a realidade lcomo de fato estā sendo e não como o discurso ofi cial diz que ela $\bar{l}$ ), realidade vivida pelos educan dos e pelos educadores, percebemos a inviabilidade de uma educação neutra". (1984:29)
"... jā que a educação modela as almas e recria os corações, ela é a alavanca das mudanças sociais" (1984:32).

Ele continua esclarecendo que a transformação social correspon de a um processo histōrico em que a subjetividade e objetivida de se prendem dialeticamente. Ainda segundo Paulo Freire não é possível praticar sem avaliar a prática e analisar o que se faz, comparando os resultados obtidos com as finalidades que procuramos alcançar com a prática.

A nossa tarefa revolucionāria inclue alēm de informar, formar corretamente.

A maioria das anālises que envolvem o trabalho do me nor expressam essa atividade como sendo necessāria a sua autosustentação ou mesmo para complementação da renda familiar. Me diante tal situação esta atividade é uma forma de sobrevivência ou mesmo reprodução de famīlias carentes, o que não se pode ne gar mediante a constatação do real.

A reflexão que se efetua corresponde à anālise desse trabalho sob outro àngulo. Na realidade social ele se amplia e 
a sua participação no processo produtivo contribui efetivamente para a reprodução do capital; como observou Spindel (1986:6):

$$
\begin{aligned}
& \text { ".. tem se mostrado necessārio captar o trabalho do } \\
& \text { menor nos processos que regem a reprodução econômi- } \\
& \text { ca da sociedade, procurando um conhecimento que sir } \\
& \text { va para desmistificar algumas premissas assumidas co- } \\
& \text { mo justificativas aos 'usos' e 'abusos' que o capi } \\
& \text { tal faz desta mão-de-obra, tais como a sua baixa pro } \\
& \text { dutividade, menor qualificação, baixa escolaridade, } \\
& \text { o carāter complementar de seu salārio, etc." }
\end{aligned}
$$

pois ele é parte integrante e estrutural do processo social de produção.

E fundamental considerā-lo como um segmento específico da força de trabalho; pois ele constitui uma categoria que no interior de sua classe possue uma trajetōria histórica prō pria; com características peculiares; de idade, de experiência, e de produtividade que não podem ser esquecidas, devem ser des vendadas em todas as suas implicações. E atravēs destes argumen tos que se efetuam a super exploração dessa força de trabalho em formação; atribuindo-lhes remuneração menor.

Como observou Cortēs (1986:45) no seu trabalho:

"... este quadro vai implicar, direta ou indiretamen te, no rebaixamento do custo da força de trabalhoco mo um todo, como também num controle politico e $\underline{i}$ deológico sobre os trabalhadores. A 'superioridade' da remuneração da força de trabalho do adulto, sua inserção diferencial na escala de produção de empre gos são apresentadas aos menores como a recompensa legitima a uma situação natural e justa; através des sas prāticas, mantém-se a garantia de disciplina e 'docilidade' exigidas para a reprodução das condições de produção". 
No que se refere ao mercado este trabalho aparece ro tulado como tendo vantagens diferenciais frente a outros segmen tos da força de trabalho.

0 menor se caracteriza como saida vantajosa para o em pregador, no sentido de ser usada sua pouca idade e inexperiência para o desprestigiar com o intuito de desvalorizá-lo.

De forma nenhuma deve ser esquecido que este trabalho gera valor, independente de sua quantidade; como tal contribui para o crescimento do grupo social em que está inserido.

Ao tentar investigar o problema do menor com maior pró fundidade, chegamos à anālise de suas famīlias,que na sua quase tota lidade se fixaram no Jardim Peri na década de 60 , fruto do pro cesso social migratōrio.

Segundo a constatação de Milton Santos (1985:81)

"A cada período da histōria corresponde uma mudança estrutural e organizacional, e a urbanização apresenta caracteristicas particulares e requer uma de binição nova. A medida que as infra-estruturas $e$ os equipamentos necessārios à produção e ao comērcio se tornam mais numerosos e especializados, al gumas cidades se encontram numa situaçāo privilegia da".

Nota-se que a esta afirmação se vinculam outros trabă Ihos que se tem realizado, referentes a nossa sociedade.

Becker (1968:114) diz que:

"... as migrações internas constituem manifestação dinâmica de uma organização em processo de crescimento, mas de crescimento desequilibrado. E, portanto, esse desequilibrio que deve ser objeto de a 
nālise e reparação. Exprimindo as justas aspirações das massas rurais a integrarem-se na econo mia moderna e a elevar o seu padrão de vida, as migrações diluem as diferenças regionais $e$ seto riais, constituindo uma tentativa espontânea para equilibrar a organização do espaço.

Do ponto de vista estritamente econômico contribuem, efetivamente, para a urbanização do pais, pa ra o crescimento industrial do sudeste $e$, através de frentes pioneiras, promovem a integração econô mica de vastas porções do territōrio".

Gonçalves, quando analisa em seu trabalho a organiza ção do espaço ao se referir ao processo migratōrio coloca (1985: $17)$,

"... a migração é um fenômeno no qual, em nossa sociedade, o trabalhador migra para determinados lu gares onde possa vender a sua força de trabalho. Estes tais lugares são, exatamente, aqueles onde - capital está localizado ou para onde o capital estā migrando".

Referindo-se tambēm a organização do espaço Seabra có loca $(1980: 5)$ :

"... as relações sociais nas sociedades humanas não primitivas que hoje habitam o planeta não levam a uma distribuição igualitāria do produto das ativi dades dos homens. As diferenças na distribuição do produto da atividade dos homens diferencia-os quan to às disponibilidades econômicas para o emprego de técnicas $j \bar{a}$ disponiveis. Deste modo, as condi ções naturais não afetam igualmente a existência dos diversos grupos sociais que compõem a socieda de humana".

Necessārio se faz colocar as posições da Profa. Amé- 
lia Inēs Geraiges de Lemos quanto à experiência que ela possui em trabalhos realizados na periferia da cidade de São Paulo u tilizando a pesquisa participante (1987:5(. Ela nos mostra a importāncia que existe:

"... quando se compartilha o cotidiano da realidade social, quando o pesquisador convive com pessoas reais, com suas culturas e seus grupos sociais a pesquisa participante estā sendo realizada".

Relata a autora:

"Nesses contatos com os grupos populares escutāvamos e sentiamos suas histōrias de vida e através delas pudemos chegar a novas formas de explicar a realidade. Partilhamos com eles das discussões por me lhores condições de vida, a necessidade de creches, a forma de poder pagar as prestações do BNH, a $\ell \underline{u}$ ta para conseguir postos de saúde, o movimento de desempregados durante a crise de 1982-83, etc..."

continua a autora:

"O espaço, o bairro de Itaquera foi observado, des crito, interpretado e explicado a partir dos seus conflitos. Esses conflitos são os responsāveis por novas formas especiais que convivem e ao mesmo tem po se chocam".

E, mais adiante:

"A partir destas novas formas de produção do espaço - solo urbano adquire um novo conceito de valor de uso e de valor de troca, resultado do trabalho e dos conflitos entre o capital e o trabalho". 11987: 6)

Atravēs deste panorama teórico que procura ver o trá balho do menor como reprodutor da sociedade como um todo sem 
perder as especificidades de sua utilização, tenta-se recuperar a natureza social do seu trabalho e transformá-lo em objeto de es tudo.

Esse caminho suscita uma trama considerāvel de anāilse: no que se refere às condições de trabalho, das possibilidades de frequentar a escola, das formas de vida, das condições e xistentes entre situação de vida, trabalho e escola, da relação trabalho e a famīlia, da profissionalização, da participação precoce no trabalho e outros.

Mediante esta gama de questões suscitadas pela anāilse, optou-se pela tentativa de caracterizar o trabalhador menor e estudante do curso noturno como também as relações entre ele, escola, processo produtivo e a familia em um bairro da periferia da cidade de São Paulo a partir de uma pesquisa realizada de 1984 a 1988 .

\subsection{A pesquisa}

Como ponto de partida tomamos alunos da escola noturna como sujeitos desse estudo, procurando entender a importāncia da escola para ele e as relações que se estabelecem entre ele e - trabalho; é de interesse tambēm analisar o valor para o merca do desse tipo de empregado.

Foram objeto de anālise o relato de vārios meninos e meninas que estudam à noite por necessidade de trabalho para judar a familia ou para o auto-sustento, com jornada de oito ou mais horas de serviço. 
Decorridos alguns anos de prática docente no convívio com jovens que se esforçam para conciliar as duas atividades, sentimos necessidade de investigar a relação entre vida escolar e trabalho.

Tomamos como referencial empírico a EEPG Profa. Rita Bicudo Pereira, onde foram efetuadas as primeiras observaçõesea EEPG Profaelzasaraiva Monteiro por ser a outra escola do Lardim Peri. Numa fase mais avançada da pesquisa foram incluídas a EEPG Guilherme de Almeida e a EEPG Prof. Alfredo Gomes, porque elas se localizam em loteamentos vizinhos, com o intuito de se inves tigar a possibilidade de problemas semelhantes que pudessem es clarecer o estudo em questão.

A coleta de dados ocorreu em maio de 1985 a abril de 1986, atravēs da aplicação de questionārio entre os alunos de to todas as escolas, tomando-se uma classe por série cujo critério de escolha adotado foi a classe com major número de alunos pre sentes no dia; fizemos entrevistas com os alunos matriculados e desistentes, pessoal administrativo e docente.

Consultamos arquivos e atas na secretaria das escolas, dados estatisticos escolares, mapas na Delegacia Regional. Fize mos entrevistas com diretores e docentes de anos anteriores para investigar a evolução da realidade; foi de interesse também conhecer atravēs deles como se processou a ocupação do Jardim Peri e qual era a origem familiar dos alunos.

Cabem aqui, ainda, algumas observações mais recentes que levantamos dos questionārios respondidos, sobre o local de nascimento dos avós e pais dos entrevistados, com o intuito de entender os motivos que levaram essas pessoas a se fixarem na 
quela periferia.

Entramos em contato com o Instituto Fiorestal do Esta do que nos forneceu uma série de mapas com o intuito de localizar o terreno que eles doaram para a instalação da primeira es cola do bairro.

Foram efetuadas algumas entrevistas com alunos em ma $\underline{r}$ ço de 1988 que tinham por finalidade comparar a realidade atual com a de 1985 .

Os conteūdos questionados se relacionavam com a ida de, sexo, horārio de trabalho, tipo de atividade desenvolvida, contrato de trabalho, forma de pagamento.

Fizeram parte do universo da pesquisa alunos de $5^{a}$ a 8a séries do perīodo noturno das quatro escolas envolvidas na investigação.

Dos 332 alunos que responderam ao questionārio, foram aproveitados apenas os mais completos perfazendo um total de 226. Entrevistamos 66 alunos dos quais 20 eram frequentes e 46 desis tentes, as entrevistas tiveram duração em mëdia de 30 minutos e o roteiro nem sempre foi seguido com rigor para dar maior liber dade aos alunos.

As entrevistas com os frequentes foram efetuadas na escola, com os desistentes houve maior dificuldade, isto porque elas ocorreram em suas residēncias e nem sempre o endereço obti do era o mesmo. Achamos o resultado proveitoso pela oportunidade de se conhecer o ambiente doméstico dos alunos.

Foi esse o material empirico que nos forneceu elementos para as reflexões e questionamentos levantados. Um exemplar 
do questionārio está anexo no final do texto.

A fonte fundamental de informações foi o discurso dos alunos através dos questionārios e entrevistas.

0 processo de interpretação de todo o material colhido foi o eixo referencial desse trabalho, com a inclusão de da dos levantados junto aos seguintes órgãos do Estado de São Pau10 :

- Prefeitura Municipal de São Paulo - Administração Regional da Casa Verde - PMSP-AR Casa Verde;

- Secretaria Municipal de Planejamento - SEMPLA;

- Empresa Metropolitana de Planejamento da Grande São Paulo S.A. - EMPLASA;

- Centro de Estudos e Pesquisas de Administração Municipal- CEPAM (Fundação Prefeito Faria Lima);

- Divisão Regional de Ensino da Capital - DRECAP-I;

- Delegacia de Ensino - D.E. ( $2 \stackrel{a}{a}$ e $3 \stackrel{a}{a})$;

- Secretaria do Menor - Sede São Paulo;

- Fundo das Nações Unidas para a Infãncia - Sede São Paulo UNICEF.

0 texto apresenta como caracteristicas principais:

- Os cursos noturnos são frequentados por quantidade cada vez maior de crianças e jovens que, desde cedo, fazem parte do pro cesso produtivo, portanto, são explorados.

- A fala destes alunos nos revelou as condições de trabalho des ses estudantes e a pequena condição que eles possuem para com petir no mercado.

- E importante refletir sobre o trabalho do estudante no inte 
rior da sociedade capitalista em que ele vive, sobretudo, quan do a realidade é terceiro mundo, incluindo as contradições que nelas ocorrem. 
CAPITULO II

METROPOLIZAÇAO, TRABALHO DO MENOR E SUA FAMILIA 


\section{METROPOLIzAÇAO, trabalho do menor e sua familia}

\subsection{Metropolização de Säo Paulo}

A cidade de São Paulo contou com inúmeros fatores que contribuiram para que se tornasse a ārea propỉcia à expansão da indústria nacional. O café trouxe a esta região condições indis pensáveis ao processo de industrialização. A posição geogrāfica da cidade foi um dos fatores marcantes: situada na porção orien tal do Estado, o planalto próximo à serra do Mar era passagem pa ra o escoamento do café pelo Porto de Santos; este comércio criou uma infra-estrutura de ferrovias importantes para o escoamento do produto, que passava pela capital paulista.

Com o decorrer do tempo, melhoraram os serviços públi cos da cidade; foi construỉda rede de ägua e esgoto, iluminação, aproveitamento dos rios da ārea na construção de usinas hidrele tricas, instalação de linhas de bonde. Tais fatos contribuiram para que a cidade de São Paulo se transformasse em centro de grande atração para o mercado de trabalho.

Os dados do recenseamento do Brasil demonstraram isso: em 1872 no 10 censo, São Paulo ocupava o 50 lugar dentre as c $\mathfrak{i}$ dades mais povoadas, em 1900 ela jā tinha conquistado o 20 lugar perdendo apenas para o Rio de Janeiro e em 1960 ela ultrapassava o Rio de Janeiro e tornava-se a maior cidade brasileira; com 3,3 milhões de habitantes. Esta constatação inicialmente se de ve à expansão cafeeira e à concentração industrial.

Com a concentração industrial no Sudeste, inicia-se $\underline{u}$ ma nova maneira da organização do espaço. o Sudeste passa a ser 
.35 .

o espaço geogrāfico brasileiro de maior destaque.

Expande-se a rede de transportes, inicialmente as fer rovias e posteriormente as rodovias ligando as diversas āreas brasileiras às principais metrópoles. As mercadorias produzidas em São Paulo são comercializadas em todo o país, favorecidas pe los meios de comunicação que se desenvolveram. Tal realidade fá cilitou as comunicações e estimulou grandemente as migrações in ternas.

Com a industrialização, o espaço geogrāfico de São Pau 10 transformou-se, ocorreu a metropolização da cidade.

Conforme Castells:

"... o espaço é um produto material em relação com ou tros elementos materiais, entre os quais os homens, que contraem determinadas relações sociais, que dão ao espaço uma forma, uma função, uma significação so cial. E a expressão concreta de cada conjunto histōri co no qual uma sociedade se especifica". (1976:141).

A concentração das atividades industriais condicionou extraordināria expansão das atividades terciārias na região: re de bancária, lojas de comércio, a rede de ensino cresceu bastan te tanto a particular quanto a estadual como também criaram-se cursos profissionalizantes, multiplicaram-se os hospitais, pron to-socorros, clīnicas mēdicas, postos de saūde alēm de estabele cimentos de luxo: salão de beleza, clubes, escolas de prāticas esportivas.

"A porcentagem de empregos cresceu na Grande São Paulo 60\% entre os anos de 1950 e 1960". ISinger, 1980: 1241 . 
.36 .

Este fato contribuiu para que inümeras pessoas imigrassem para São Paulo em busca de melhores condições, aumentan do ainda mais o crescimento urbano.

Milton Santos nos coloca que:

"... as diferenças entre lugares são o resultado do arranjo espacial dos modos de produção particulares. o 'valor' de cada local depende de niveis qualitati vos e quantitativos dos modos de produção e da ma neira como eles se combinam". (Santos, 1974:8).

No entanto, o aumento de serviços não acompanhou o crescimento demogräfico, e logo surgiram desequilíbrios enormes entre a oferta e a demanda destes serviços, causando sērios pro blemas de moradia e infra-estrutura urbana que atingiram grande parte da população que se expandiu nos loteamentos periféricos, nas favelas e nos cortiços.

Conforme Milton Santos:

"O espaço se define como um conjunto de formas repre sentativas de relações sociais do passado e do pre sente, entretanto qualquer que seja o periodo histō rico, o espaço é o resultado da produção". ISantos, 1980:2091.

E importante que se esclareça; quando se fala do acelerado crescimento da cidade de São Paulo, a posição privilegia da dos serviços que ela tem condição de oferecer; nela se concentram os melhores hospitais, centros de saūde, instituições $\underline{e}$ ducacionais, etc., ocasionada pela sua privilegiada situação conōmica comparada com outras āreas do paĩs; nelas o aumento sem controle de sua população traz sérios desequilïbrios dos servi ços essenciais da cidade ocasionando uma deterioração da vida 
para significativo número de pessoas, originando as populações marginais.

Paul Singer analisa a cidade sobre vārios aspectos. Ressalta ele que é importante que se coloque a pujança econōmi ca de São Paulo e se mostre a relevância de sua infra-estrutura (edificações, energia elétrica, saūde, educação...) como os indicadores que mostram seu crescimento econômico intimamente ligado à indústria.

0 mesmo autor ressalta todos os problemas da grande cidade e mostra a gravidade dos mesmos e as consequéncias so fridas pela população pela incapacidade de inseri-la no desenvolvimento. Exemplifica atravēs de Castells:

".. que caracteriza a urbanização da América Latina como sendo de aceleração crescente, constituindo grandes concentrações de população sem desenvolvimen to equivalente da capacidade produtiva, a partir do êxodo rural e sem assimilar os migrantes no sistema econômico urbano, com a formação de uma rede urbana truncada e desarticulada".) "L'urbanization dépendent en Amérique Latine" in Espaces et Societés, no 3, julho 1971 pg.21)

Sobre outra ótica mostra-se a anāilse da Pontifícia Comissão de Justiça e Paz da Arquidiocese de São Paulo:

\footnotetext{
"No entanto, se examinado o desenvolvimento da cida de do ponto de vista das condiçōes de vida de seus habitantes, verifica-se um elevado e crescente des nivel entre a opolência de uns poucos $e$ as dificuldades de muitos. E a riqueza representada nas moradias suntuosas dos 'jardins', e a pobreza dos bair ros trabalhadores, carentes dos serviços urbanos bā sicos - transporte, āgua, esgoto, habitação". ("São paulo 1975, crescimento e pobreza", 1976:171.
} 
São estas algumas das caracteristicas que aparecem no loteamento que estamos nós propondo a estudar no capitulo seguin te. (vide Figura 01 ).

\subsection{O Jardim Peri na metrópole paulistana}

0 Jardim Peri constitui um dos loteamentos periféricos de São Paulo, que abriga grande nūmero de famīlias trabalhadoras da cidade. Ele está localizado na zona Norte da cidade, na Serra da Cantareira e ao lado do Instituto Florestal.

0 relevo é acidentado e esta ārea corresponde aos con trafortes da Serra da Cantareira cuja altitude é de $775 \mathrm{~m}$, o que The dá caracterīsticas especīficas, muito bonitas do ponto de vista natural.

A população que alī se instalou está distribuida en tre o Parque Estadual da Capital (1)(Instituto Florestal) e a Reserva Estadual da Cantareira (2); a ocupação do lugar teve seu início com dois núcleos de população, um no cume do morro, prō ximo ao Instituto Florestal, outro no sopé do mesmo morro e se expandiu pela encosta atingindo outras āreas da serra.

(1) Parque Estadual da Capital - ārea que se presta a pesquisa, recreação e lazer.

(2) Reserva Estadual da Cantareira - área que se presta para pesquisa cientīfica, aguardando definição adequada para ma nejo.

Estes esclarecimentos foram fornecidos pelo engenheiro do Instituto Florestal. 


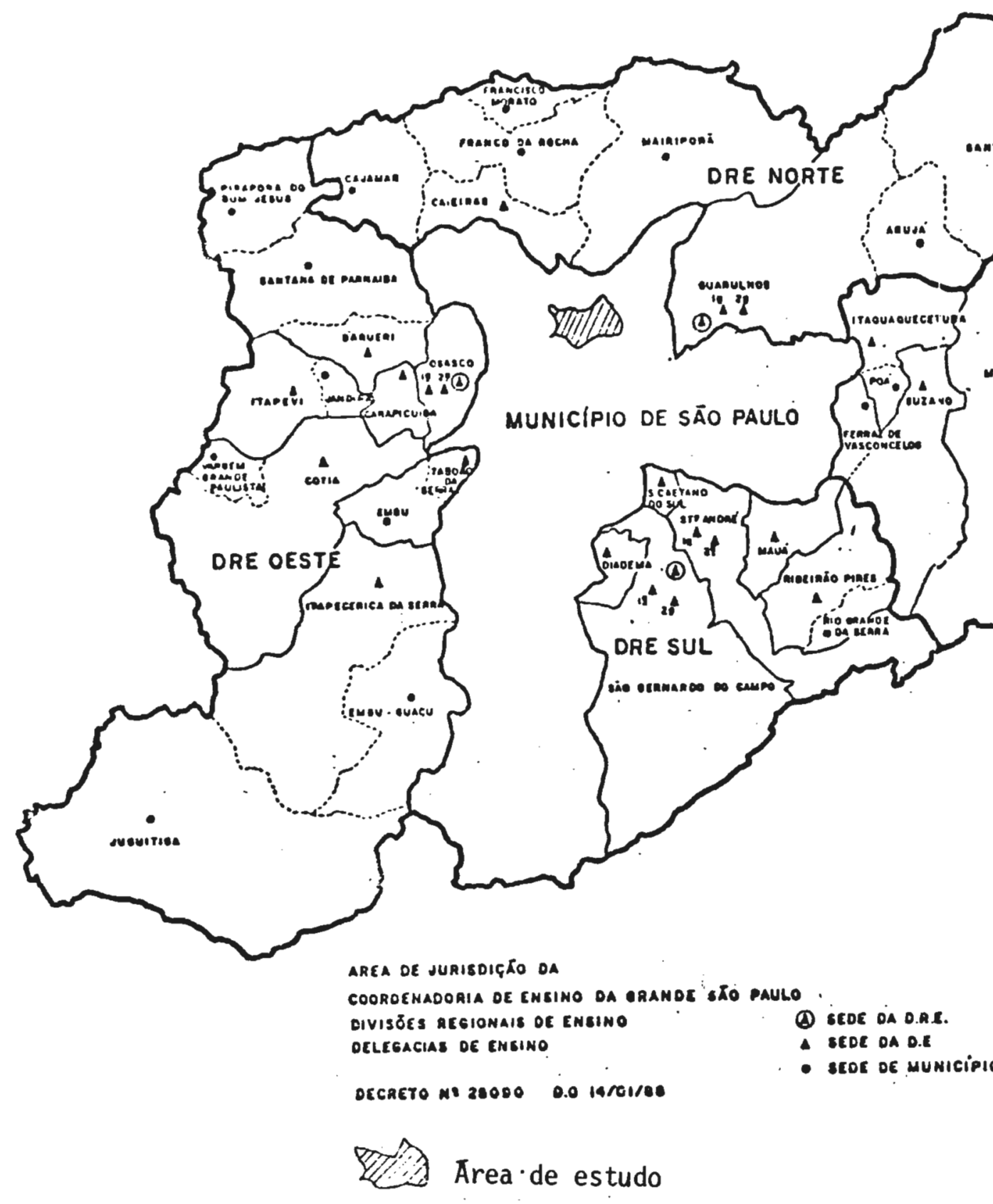

Fonte: SECRETARIA DE ESTADO DA EDUCAÇĀO

ASSESSORIA TÉCNICA DE PLANEJAMENTO E CONTROLE EDUCAC:ONAL - ATP: CENTAO OE INFORMAGŌES EDUCACIONAIS - CIE

SÃo PAULO EXTERIOR 
Ela ocorreu de forma irregular, as ruas são tortuosas e acompanham as irregularidades do relevo. 0 crescimento do Jar dim Peri se fez de forma desconexa e sugerem momentos distintos de ocupação do solo. (vide Figura 02).

Gradativamente foram ocorrendo transformações: a popu lação aumentou sensivelmente a partir da década de 1960; foram surgindo imigrantes atraidos pelas vantagens reais ou supostas, que a dināmica metrópole paulista passou a oferecer tamanha a febre de construções e tão poderosa sua força econōmica.

Sem condições, fixaram-se na periferia em habitações im provisadas de madeira. 0 aumento populacional do Jardim Peri $\underline{0}$ correu desta forma; no início a construção dos barracos eram distantes entre si, com o aumento considerável de pessoas a si tuação se complicou e houve necessidade de acomodar um número ca da vez maior de pessoas em um espaço menor, dando origem as ca racteristicas de favelas daquele loteamento que era clandestino.

Bertha Becker (1968:114), em seu estudo sobre migra ções chama a atenção para o fato de que:

"... as migrações internas, processo espontâneo de re organização do espaço gerado pelos desequilíbrios re sultantes das formas de implantação industrial, ainda que contribuindo para o crescimento econômico do pais, o fazem de forma penosa e insatisfatōria".

Essas pessoas vivem em acomodações restritas, geralmen te são famīlias numerosas que se acomodam em um quarto que é tambēm cozinha, separada por algumas tábuas.

os responsáveis pela casa trabalham em locais distantes e permanecem fora o dia todo. As crianças que geralmente nes 


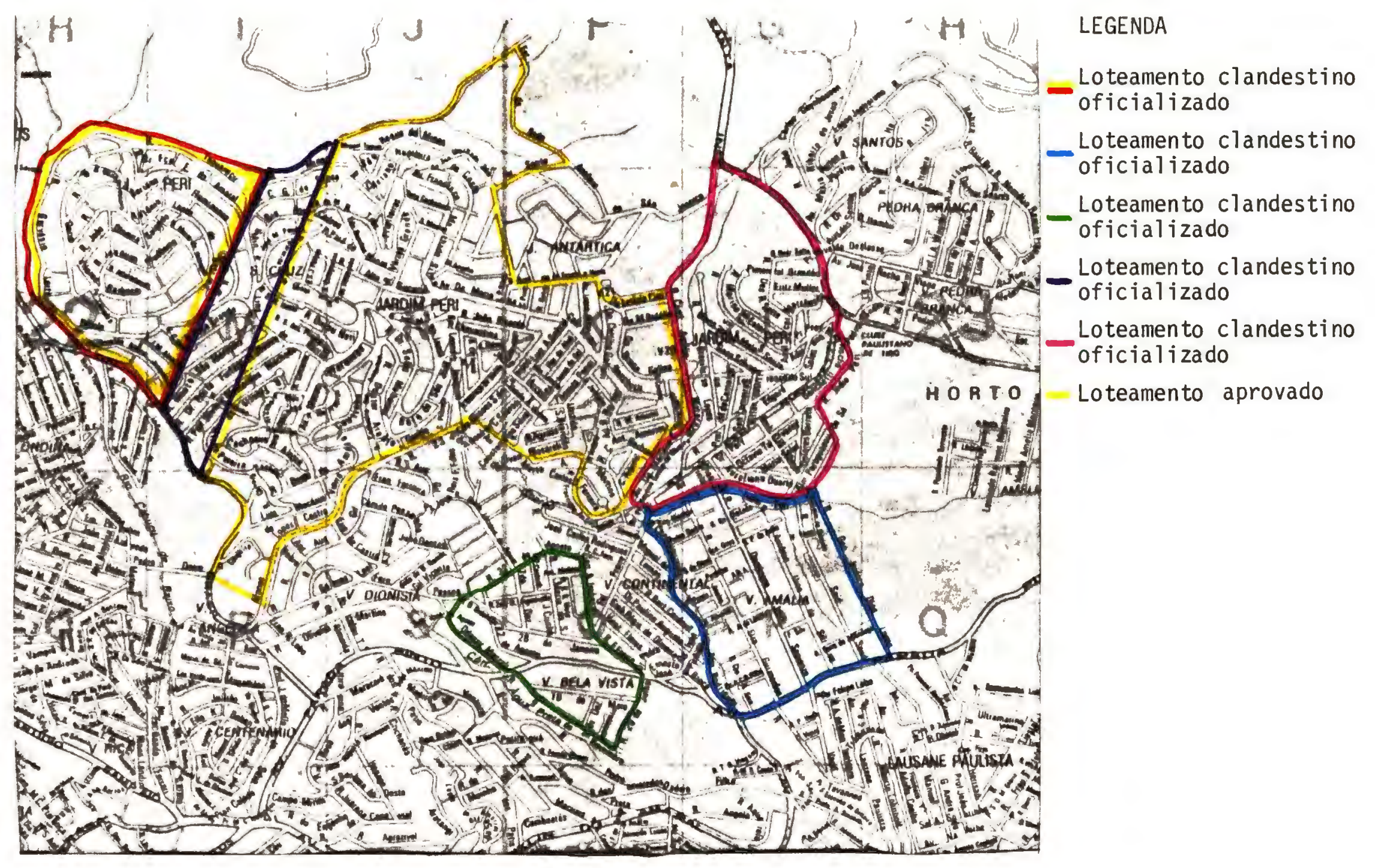

ESCALA

Fonte: SEMPLA/EMPLASA S/D

ESCALA APROX. 1/20.000

FI GURA 02 
sas famillias são numerosas ficam sozinhas; sendo atribuîda às mais velhas a responsabilidade de cozinhar, lavar e cuidar dos irmãos menores, atē o momento que elas tambēm possam participar do mercado de trabalho.

E importante esclarecer que o Jardim Peri não é cons tituido só por favelas, elas são três e a maior parte da população mora em casas de alvenaria; embora possam ser caracterizadas como famỉias de trabalhadores de condições modestas.

Nos ūltimos anos a ārea sofreu modificações significativas; a população aumentou consideravelmente e surgiram na quele lugar algumas indústrias artesanais como fäbrica de vas soura, confecção de roupas, de lustres; multiplicaram-se as ca sas comerciais, o super-mercado foi substituido por outro maior; na avenida principal foi instalado consultōrio dentārio, médi co e a população ganhou um posto de saúde do Estado.

As residencias da avenida principal estão sendo subs tituidas por sobrados modernos o que significa que as familias mais simples estão sendo obrigadas a se deslocar para locais mais distantes e o solo vem sendo ocupado por residencias de pessoas com maior poder aquisitivo.

o movimento na ārea aumentou muito, nota-se um fluxo maior de ōnibus e carros, o movimento das lojas comerciais é grande e o vai e vem de pessoas é constante.

Como jă mencionei anteriormente trabalho nesse lugar desde 1972 quando fui lecionar na EEPG Profa. Rita Bicudo Pe reira para alunos de quinta e sexta séries; o funcionamento de sētima e oitava séries teve inīcio no ano seguinte. 
No periodo anterior ao ano de 1972 a escola assistia alunos de $1^{\mathrm{a}}$ e $4 \stackrel{\text { a }}{\text { séries. }}$

No decorrer desses anos tive um número significativo de alunos, cada um deles enfrentando problemas diversos e pude observar que as salas de aula em março estão cheias, a partir de julho a frequéncia fica reduzida à metade continuando a de crescer até dezembro; além de se constatar alunos dormindo nas últimas aulas do período noturno, motivos que me levaram a uma investigaçãc mais profunda.

Como a nossa proposta é analisar o relacionamento en tre menor, escola e trabalho, com alunos do periodo noturno, $\underline{\mathbf{i}}$ niciamos fazendo investigação na EEP.G Profa. Rita Bicudo Pere ra com alunos de primeira a oitava séries. Encontramos menores trabalhadores desde os sete anos; constatamos alunos que ven diam sorvete na rua, catavam bolinha de tênis no clube nos fins de semana, ajudavam em banca na feira, carregavam sacola na feira, empacotavam no super-mercado.

Entre alunos de primeira a quarta séries o número dos que trabalhavam era pequeno como tambēm entre os estudantes do perīodo vespertino de quinta, sexta e sētima séries porque a oitava sērie funciona só no perīodo noturno.

Mediante tal constatação delimitamos a ārea a ser es tudada entre quinta à oitava séries do perīodo noturno por es tar nela a maioria dos alunos que trabalhavam.

No decorrer da investigação sentimos necessidade que 
esta anālise se estendesse a outras escolas a fim de que pudés semos estabelecer comparação entre elas.

Assim resolvemos incluir na área em estudo a EEPG Profa. Elza Saraiva Monteiro porque ela faz parte do mesmo lo teamento e as EEPG Guilherme de Almeida, EEPG Prof. Alfredo Go mes por estarem localizadas em loteamentos vizinhos. A inten ção é investigar se ocorrem nelas os mesmos problemas. (Fig. 3 ).

Em outro nível de constatação, no livro "São Paulo, 1975, Crescimento e Pobreza" (1976:17) colocam:

"... contando com a maior parte da economia indus trial do Estado e tendo-se conservado por vārias décadas à frente do processo de concentraçāo, a Grande São Paulo transformou-se num vasto conglomerado, com uma população de quase 11 milhões de habitantes dos quais $96 \%$ vivem em āreas urbanas".

Tal fato mobilizou a população brasileira à procura de trabalho, aglomerando-se na periferia da cidade.

"A peculiaridade de são paulo talvez resida, principalmente, na exacerbação do contraste entre acu mulação e pobreza". (1976:19)

Com a expansão da cidade tornou-se necessārio o a $\underline{u}$ mento de serviços para atendimento da população o que não acom panhou o ritmo do crescimento populacional, ocasionando uma serie de problemas sociais comuns nas āreas de periferia das grandes cidades. 
SECRETARIA DE ESTADO DA EDUCAÇAOO

LOCALIZAÇAO CA AREA DE ESTUDO

(3르 DE DA DRECAP-1)

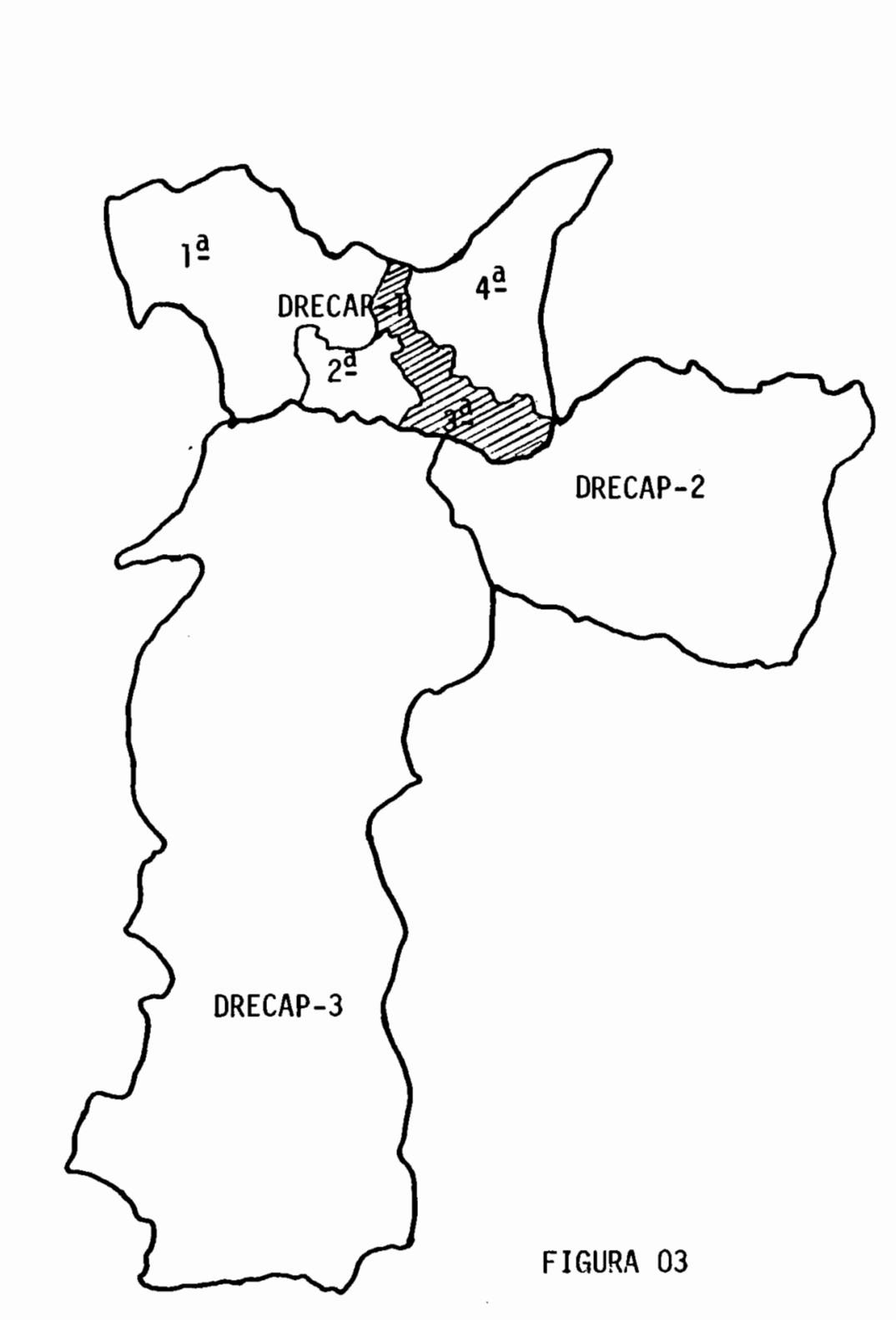

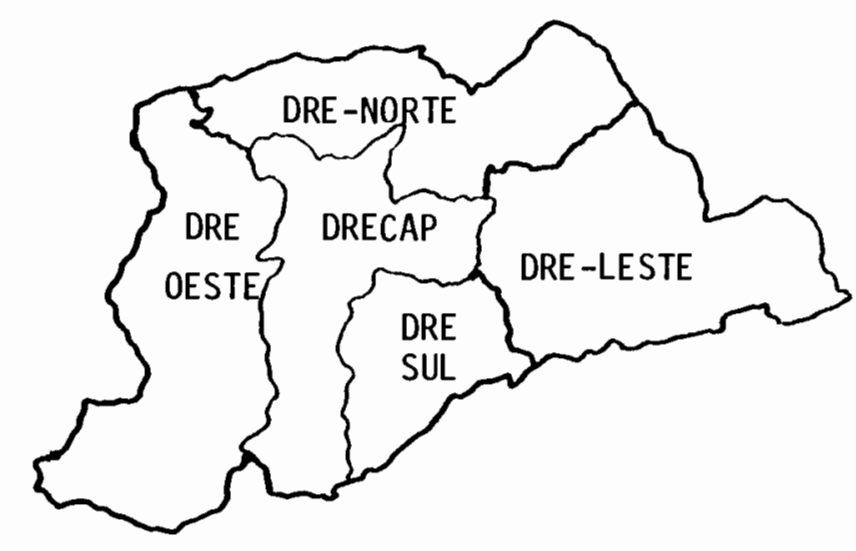

ESCALA

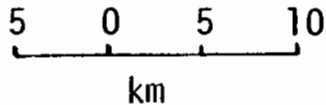

MUNICIPIO DE SÃO PAULO

DRECAP-1

$I^{\mathrm{a}} \mathrm{DE}$

1- PERUS

2- JARAGUA

3- PIRITUBA

4- JAGUARA

5- BRASILANDIA

2- DE

6- NOSSA SENHORA DO 0

7- LIMAO

8- CASA VERDE

9- VILA NOVA CACHOE IRINHA

3 $\stackrel{\text { a }}{D E}$

10- SANTANA

11 - VILA GUILHERME

12- VILA MARIA

4ㄱ- DE

13- TUCURUVI 


\subsection{O crescimento da população e a jundação das es-}

colas

A EEPG Profa. Rita Bicudo Pereira teve seu inicio em 1959 com o nome de Grupo Escolar do Horto Florestal, foi cria do nos termos dos Artigos 201 e 205 do Decreto 17.698, de 26 de novembro de 1947 por a to de 26 publicado a 27 ambas datas do mēs de maio de 1958, retificado por Decreto de 26 publicado a 27 de novembro de 1958 com quatro classes, mediante a anexação

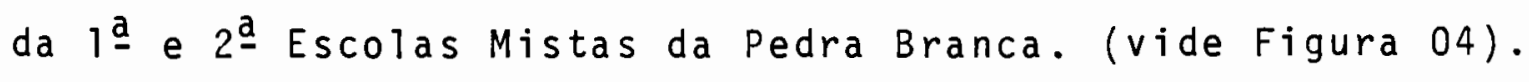

- Data da criação - 26.05.58

- Data da instalação - 16.02.59

Começaram a funcionar 4 classes da primeira à quarta sēries no periodo da manhã com:

Matriculados desde o começo do ano

Masc. Fem. Tota]

Eliminados desde o começo do ano

Restante

$$
\begin{aligned}
& \begin{array}{lll}
62 & 108 & 170
\end{array} \\
& \begin{array}{lll}
13 & 24 & \frac{37}{84}
\end{array}
\end{aligned}
$$

Fonte: Documentação da Escola

A Profa. Diva, que trabalhou na escola naquele perīo do nos relatou:

"A escola funcionava em um galpão de madeira construí do no terreno da esquina entre Av. Santa Inês com o inicio da Av. Peri Ronchetti, cedido pelo Instituto Florestal do Estado. No ano seguinte, os alunos au mentaram e foi ampliado o número de classes, passando a funcionar duas delas também no período da tarde. A clientela que a escola atendia boi sempre muito po 


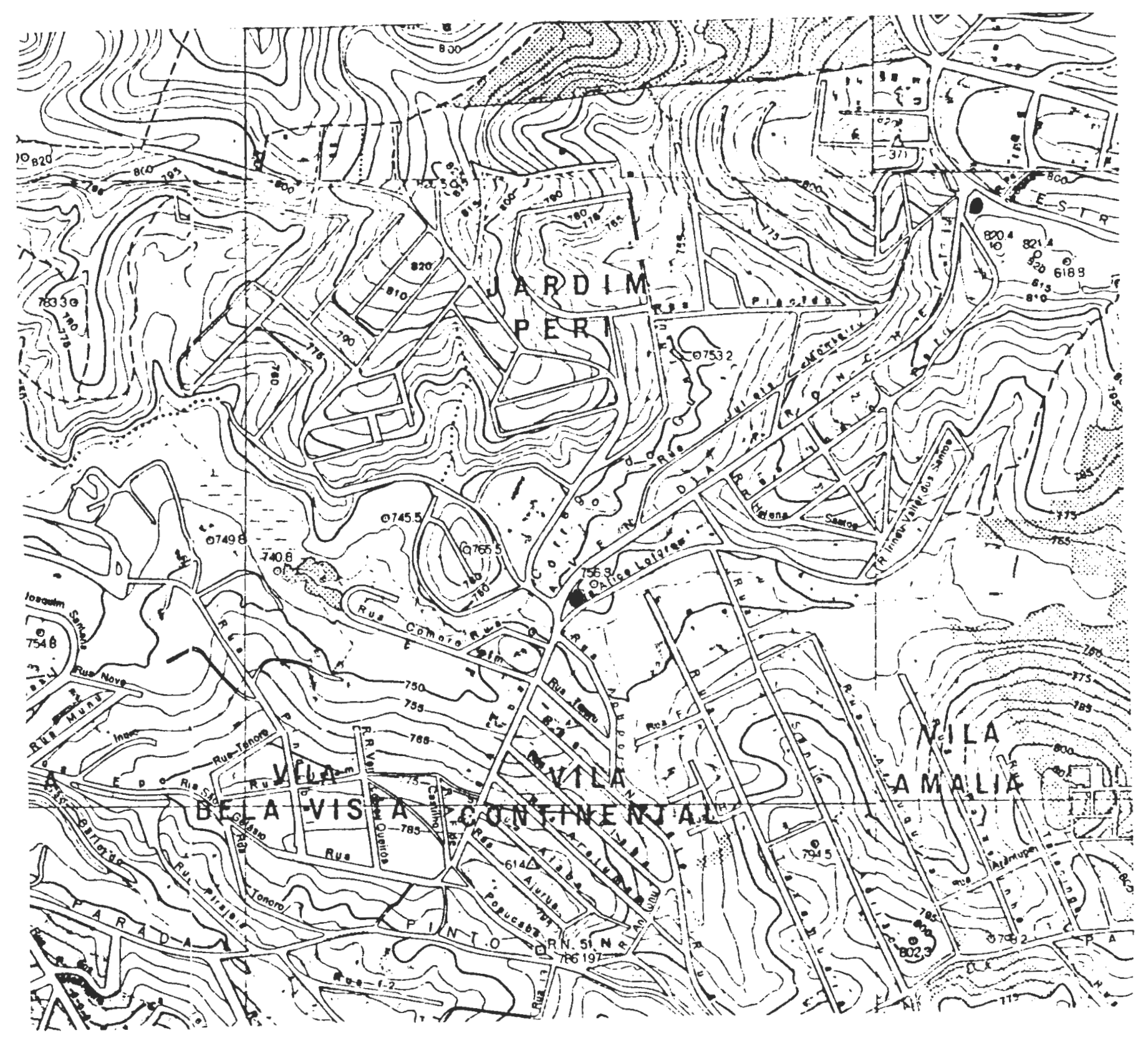

\section{LEGENDA}

Funcionando

Previstas

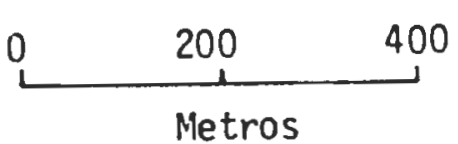

Fonte: PMSP/VASP-CRUZEIRO - MUNICIPIO DE SAOO PAUL0/1959 
bre: grande parte dos alunos residiam em locais dis tantes da Serra da Cantareira e andavam quilômetros para chegar. Apesar disso, eram assiduos e gostavam de estudar. Nessa época as classes chegavam a ter 49 alunos, as carteiras eram duplas e os menores sen tavam em três. Nesse período os problemas não eram tão sérios, pelo menos no que se refere à alimentação: as familias, apesar de pobres, alimentavam bem seus filhos, elas tinham horta no fundo do quintal, cultivavam legumes e verduras para enriquecer a ali mentação. Os alunos pertenciam a familias paulistas. o aumento dos alunos foi gradativo e se acentuou a partir de 1962 com a presença dos migrantes mineiros $e$ nordestinos tornando-se mais evidente a carência alimentar das crianças".

Nōs constatamos que as deficiēncias do ensino em São Paulo remonta periodo anterior aos anos 60 quando temos conhecimento que escolas funcionavam em instalações improvisadas, com classes super-lotadas e que na época a merenda escolar foi criada pelos professores; quando cada um contribuia com uma par cela, alēm de recorrerem a doações de algumas casas comerciais do lugar; contavam tambēm com doações de legumes e verduras do Instituto Florestal. Tal comportamento se deve ao fato de se constatar a carēncia alimentar entre os escolares.

A professora continua dizendo:

". para tentar solucionar esse problema os professores resolveram pedir a colaboração do Diretor do Instituto Florestal do Estado que mandou ampliar a escola construindo uma cozinha de alvenaria, uma sa la pequena, um galpão para abrigar as crianças nos dias de chuva, isto porque anteriormente elas se $\underline{a}$ brigavam em baixo das salas de aula, que eram construídassobre pilares. Ele mandava também diariamente 
um caminhão de ägua para abastecer a caixa da esco la; enviou por inümeras vezes pedriscos: para melho rar as vias de acesso à escola, isto porque a re giāo é acidentada e não era calçada, na época de chuva formava-se muito barro. Isso ocorreu de 1959 até 09 de setembro de 1965 quando foi inaugurado o prédio novo de alvenaria, que foi construído na ges tão do governo Carvalho Pinto e inaugurado pelo go vernador Adhemar de Barros, localizado na Av. Peri Ronchetti, 494, com o nome de GE Profa. Rita Bicudo Pereira. A partir da $\vec{i}$ a escola mudou-se para o pré dio novo com melhores condiçöes e jā havia 22 clas ses formadas".

Através da documentação da escola conseguimos levan tar o número de alunos matriculados em 1965, que correspondiam a:

Matricula desde o início do ano

Masc. Fem. Total

Eliminados desde o inicio do ano $\begin{array}{lll}686 & 619 & 1.305\end{array}$

Restantes $\frac{146}{540} \frac{128}{491} \frac{274}{1.031}$

Prē-primārio

Masc. Fem. Total

Matriculados desde o início do ano $\begin{array}{lll}35 & 41 \quad 76\end{array}$

El iminados

$-\frac{3}{32} \frac{0}{41} \quad \frac{3}{73}$

Restantes

O Jardim Peri no fim dos anos 50 possuia dois peque nos núcleos populacionais que se distribuiam da seguinte forma: um no início da Av. Peri Ronchetti próximo à Pedra Branca e ao Instituto Florestal, local que está a uma altitude de $816 \mathrm{~m}$ da Serra da Cantareira, e o outro se desenvolveu no fim da Avenida, 
ārea que possui uma altitude de $749 \mathrm{~m}$. A encosta da serra corta da pela Avenida Peri Ronchetti era uma ārea totalmente vazia re coberta por vegetação. (vide Figura 05).

A urbanização que se desenvolveu no fim da Avenida e ra assistida pelas escolas isoladas do Jardim Peri que iniciaram seu funcionamento no dia 16 de fevereiro de 1955.

Dados obtidos na escola mostram o nümero de alunos que ela atendeu até 1960 .

$\begin{array}{ccc}\text { ANO } & \text { ALUNOS } & \text { CLASSES } \\ 1955 & 94 & 04 \\ 1956 & 48 & 03 \\ 1957 & 45 & 03 \\ 1958 & 43 & 02 \\ 1959 & 41 & 02 \\ 1960 & 46 & 02\end{array}$

Este histōrico corresponde a década de 1960, quando o Grupo Escolar do Jardim Peri deixou de ser escola isolada.

"o Jardim peri era um loteamento de periferia pobre ..."

relatou uma professora daquela época:

"... não havia favela, as casas eram de alvenaria pobre, possuiam quintal com horta e criação de ga linha, pato. Aqui era uma escola quase de roça, a quele tipo bem de zona rural. A clientela era ca rente como ainda $\bar{e}$. A escola funcionava em duas sa las de madeira, não havia diretoria e tinha um ba nheiro para todos; funcionavam três períodos, de manhã duas segundas séries, no período intermediā- 


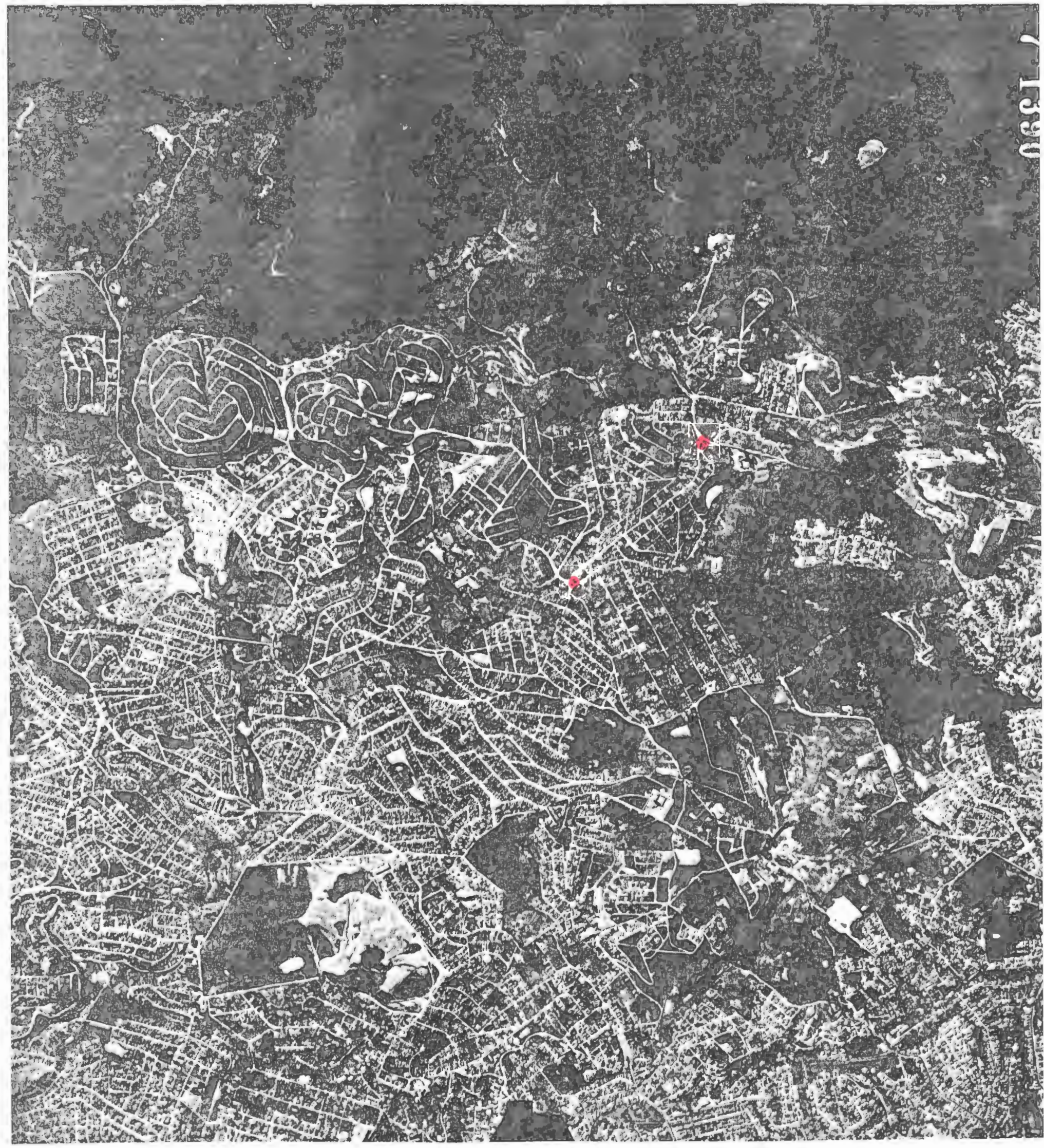

Fonte: INSTITUTO AGRONŌMICO MUNICIPIO DE SAOO PAULO/1962

ESCALA

$$
\frac{\frac{1}{1} \underbrace{250}_{1} \quad 500}{\text { Metros }}
$$


rio duas primeiras sēries $e \bar{a}$ tarde uma terceira série e uma classe anexada com terceira e quarta séries. Em 1963, quando foi construido o GE da Vila Amälia professores e alunos foram transferi dos para $l \bar{a}$, porque era mais perto para eles do que ir a té o GE do Horto Florestal. Com a construção do GE Profa. Rita Bicudo Pereira na Av. Peri Ronchetti, 494, muitos alunos voltaram a estudar no Jardim peri porque esta escola passou a ser mais perto para aqueles que moravam no Jardim peri em relação a Vila Amälia; eles se transferiram para - GE Profa. Rita Bicudo Pereira no inicio do ano seguinte em 1966".

Constatamos nos depoimentos efetuados sobre as escolas do Jardim Peri que elas eram semelhantes tanto na precariedade das instalações quanto na clientela humilde que atendiam e que a assistēncia por parte dos órgãos do Estado era inexpressiva. (vide Fig. 06).

A professora Diva continuou seu depoimento sobre o

GE Profa. Rita Bicudo Pereira:

"O nūmero de alunos foi crescendo anualmente e o aproveitamento chegava a ser satisfatōrio, isto porque a escola contava com uma equipe de profes sores dedicados que se preocupavam com os alunos mais fracos e davam aulas de recuperação fora do horärio; embora não houvesse acomodação, as crian ças eram reunidas em volta do poço no fundo da escola e se dava revisão dos ensinamentos que porventura elas não tivessem conseguido aprender. Dessa maneira conseguia-se boa promoção no fim do ano.

$\bar{E}$ importante lembrar que a escola sempre contou com a colaboração da Sociedade Beneficiente Santa Rita, que fornecia anualmente uniformes, calçados para serem distribuidos aos mais necessita dos. 


\section{LOCALIZACATO DAS ESCOLAS}

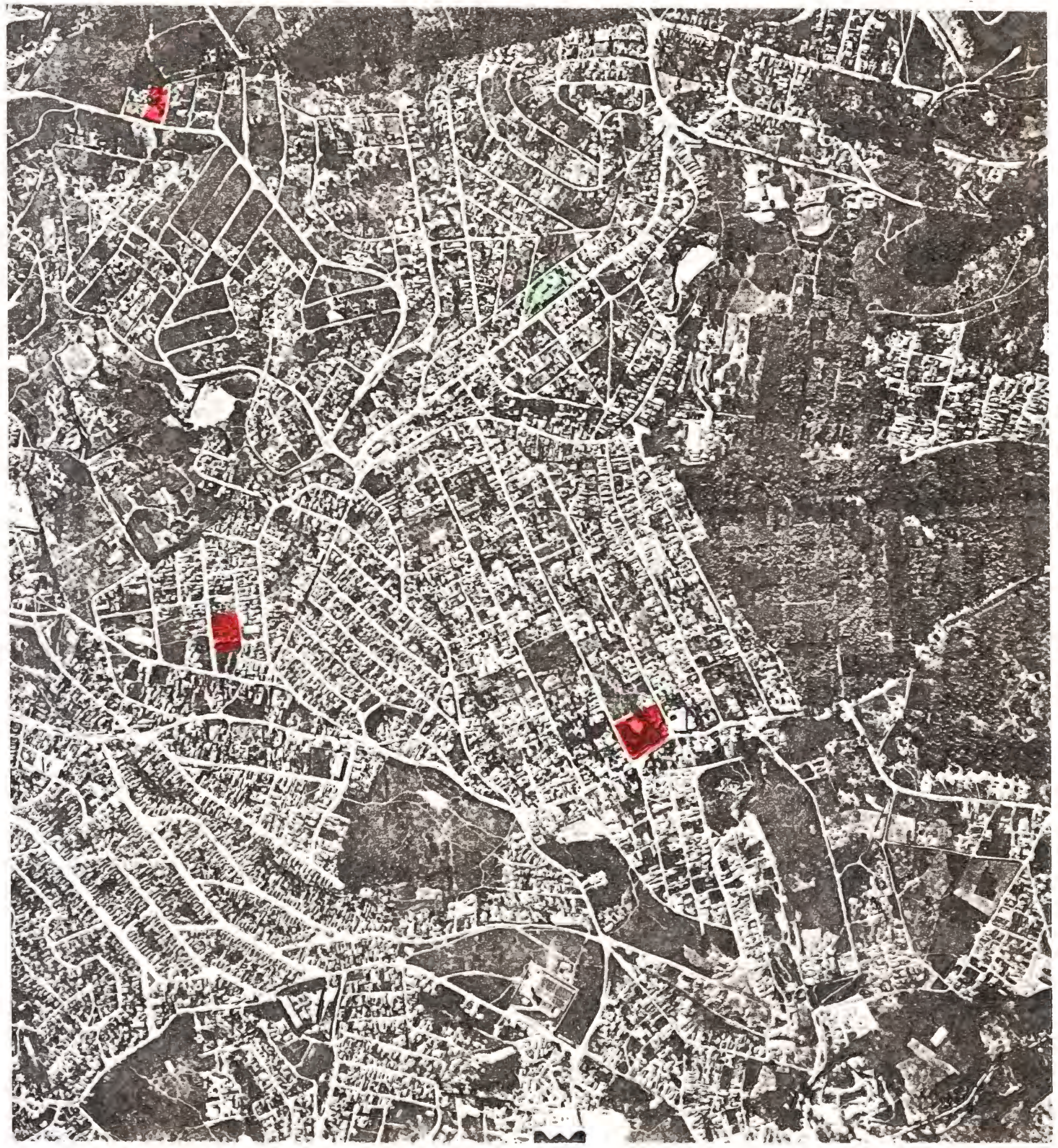

Fonte: Ministério da Aeronāutica

ESCALA

ESCOLAS

Município de São Paulo/

1967

$0 \quad 100 \quad 200 \quad 300$

FUNCIONANDO

Metros 
Os professores também sempre se prontificavam a ajudar, diante de qualquer problema se reuniam pa ra solucionā-lo, organizando mutirão de arrecada ção, fazendo bazar com roupas e alimentos cuja ren da era revertida para a caixa escolar com finalidade de atender aqueles que não tinham recurso al. gum".

Com o aumento populacional do Jardim Peri, o espaço físico do GE Profa. Rita Bicudo Pereira não teve mais condições de atender a todos que o procuravam.

A 4 - Delegacia de Ensino da Capital que assistia aque le setor da cidade, sentiu necessidade de criar salas de aula isoladas no morro do Jardim Peri Novo, para assistir as crianças pequenas que não tinham condições físicas de se deslocarem a pé até a Av. Peri Ronchetti, a distāncia era aproximadamente de $3 \mathrm{~km}$ de morro.

0 Prof. Josē Ademir que foi um dos pioneiros a traba Thar nas classes do Jardim Peri Novo relata:

"Ela começou com três salas isoladas criadas pela Delegacia de Ensino que funcionava na Capelinha da Paineira.

- Padre Eduardo cedia o espaço da Igreja, a Delegacia mandou as carteiras e os probessores lecio navam em três periodos. O nosso espaço de trabalho era o mesmo do culto religioso, no início da sema na nós afastāuamos os bancos da igreja e colocāua mos as carteiras para os alunos se acomodar, a lou sa era montada no altar do padre. Esta situação permanecia até a sexta-feira, nesse dia no fim da aula era nossa incumbência arrumar a igreja para - culto religioso do fim de semana; isso se repe tia semanalmente". 
Essas classes isoladas estavam agregadas ao GE Profa. Rita Bicudo Pereira, que dava-lhes orientação e supervisão.

o Professor continuou dizendo:

"... nōs enfrentāuamos problemas também com os pais, quando se desentendiam corriam para a escola, nāo sei se era por causa dos bilhos, do probessor ou por que iam procurar apoio do padre para intermediar no entendimento;"

e chamou nossa atenção quando descreveu o comportamento diferen te daquelas pessoas:

"... eram migrantes do interior dos vārios estados do Nordeste, constituiam familias bem estruturadas, ra ramente saiam de casa; passavam horas na janela das salas assistindo o desenrolar das aulas. Os alunos não possuiam noção de escola, não tinham caderno, nem lāpis. O professor dava o material diariamente porque eles perdiam; interrompiam a aula para levar marmita do pai no trabalho, enfim no meu entender a escola para eles era o lugar de recreação do padre Eduardo.

Mais tarde o Dr. Renato, que era protestante e tinha muitos terrenos no lugar construiu duas salas de alvenaria para a escola: a partir dai começaram a funcionar duas classes por período".

Dados levantados nos documentos da escola nos deram có nhecimento que essas classes isoladas começaram a funcionar no 20 semestre de 1971 em trēs períodos com os seguintes alunos:

HORARIO

7 h45/ $10 \mathrm{~h} 25$

$10 h 45 / 13 h 45$

$13 h 45 / 16 h 45$

\section{SERIE}

10 ano

10 a no

20 a no
MASC. FEM.

20

20

16

15

15
TOTAL DE ALUNOS

$$
40
$$

30 
.56 .

Estas classes isoladas existiram até o ano de 1977 quando passaram a fazer parté da EEPG Profa. Elza Saraiva Mon teiro em um prédio constrüido para funcionar a escola.

A população continuou se expandindo, ocupando toda a encosta da montanha. A demanda populacional era tão grande que foi necessārio criar no GE Profa. Rita Bicudo Pereira o curso ginasial (na ēpoca) no ano de 1972 para atender os alunos que terminavam a quarta sērie; estas crianças não tinham idade pa ra frequentar escola muito distante dali. (vide figura 07).

No gināsio começaram funcionar quintas e sextas sé ries e as aulas eram ministradas das 15 h00 às 19 h00, o periodo noturno teve inỉcio em 1973 com os alunos maiores, sétimas e oitavas séries; nos anos seguintes as matrīculas aumentaram sig nificativamente, passaram a funcionar todas as salas do prédio em quatro periodos tendo um intervalo de 30 minutos entreo ves pertino e o noturno (19h00 às 19h30); as aulas tinham seu in $\underline{i}$ cio às 7 hoo e o seu término às 23 hoo.

Refletindo sobre os depoimentos efetuados constatamos que apesar da ampliação gradativa da rede escolar ela nunca con seguiu atender a demanda da população que foi sempre maior.

A EEPG Profa. Elza Saraiva Monteiro que foi criada pelo Decreto 9.909 de 17.06 .77 publicada no D.0. de 18.06.77, passou a funcionar no dia 12.09 .77 formada com classes que vie ram da EEPG Profa. Rita Bicudo Pereira e da EEPG Profa. Raquel de Assis Barreiro. Ela foi construída no Jardim Peri Novo para atender a demanda populacional que se expandiu naquele morro.

Nesse final de ano ela estava constituida com: 


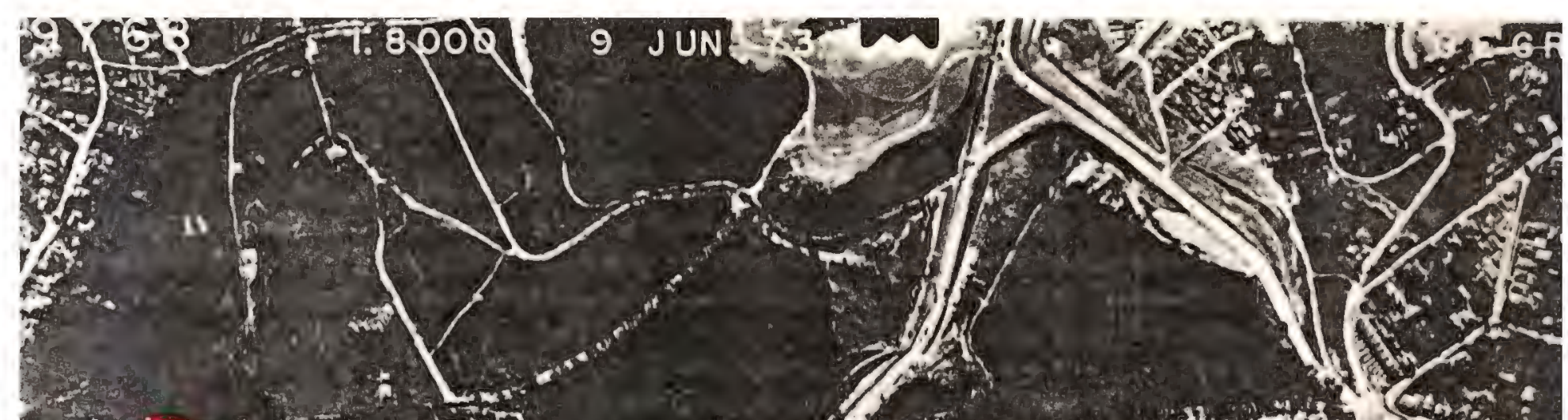

W. W.

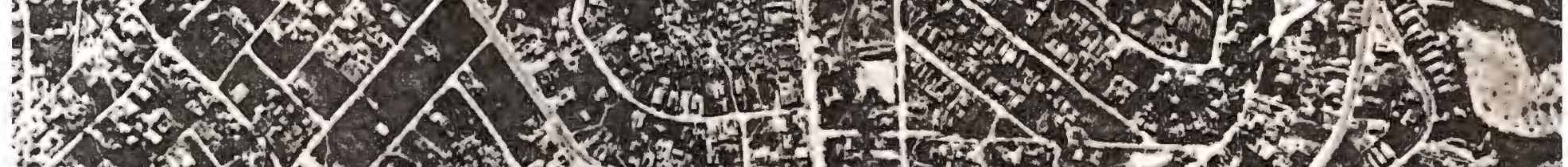
(2)

\section{1.}

- 20100

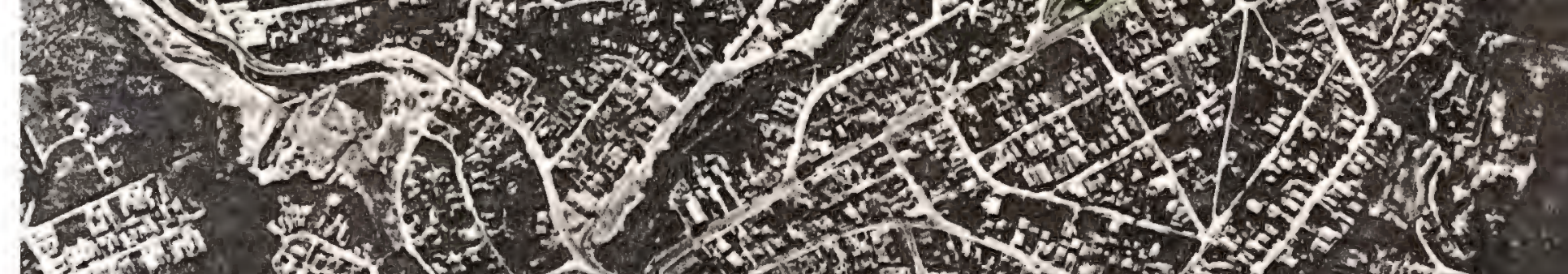

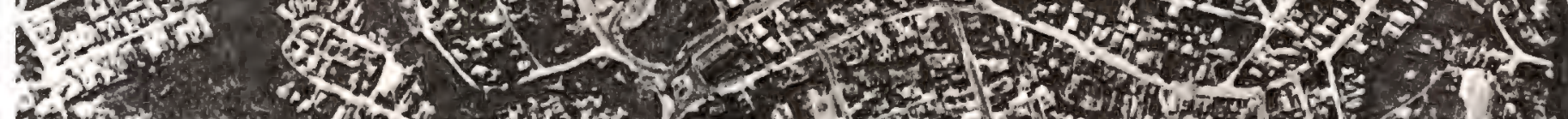
and 3 ing

3.

1.

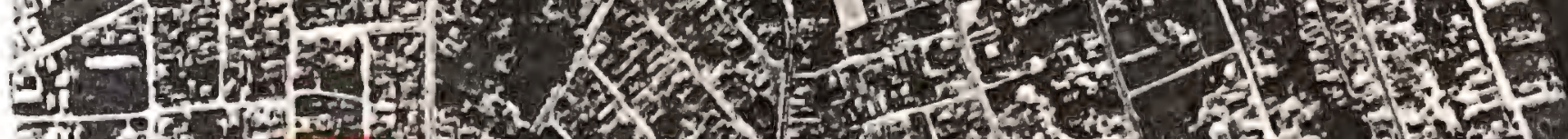

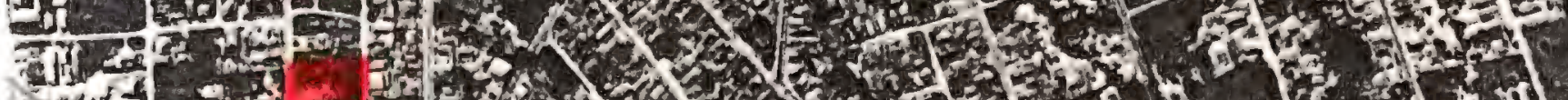

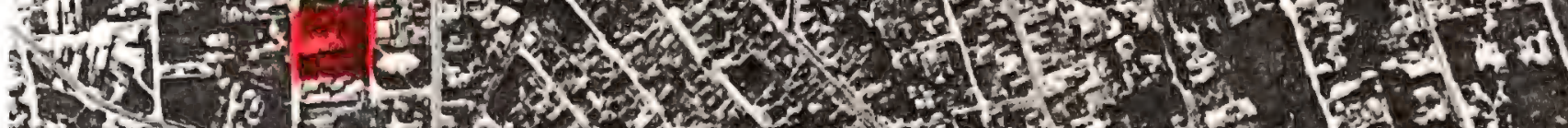

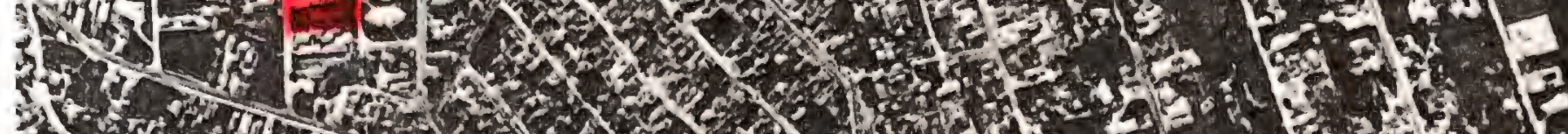
1.

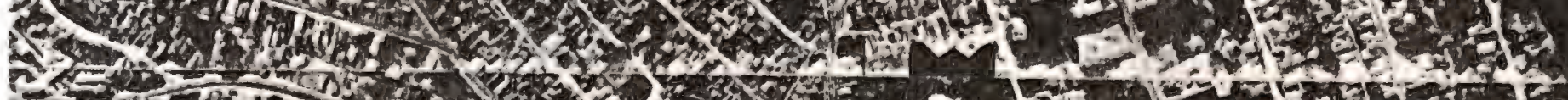

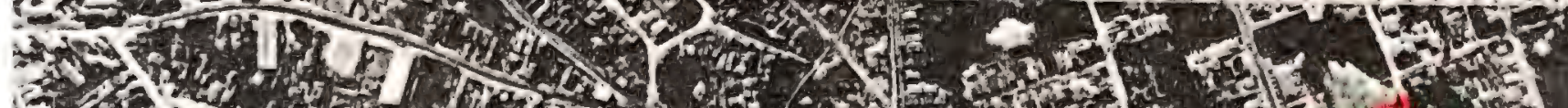
te 5 (

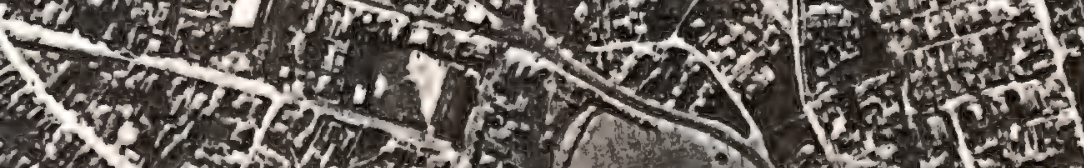
Fon. 
Nọ de alunos - 676

Nọ de classes - 19 de $1 \stackrel{a}{a}$ a $4 \stackrel{a}{a}$ séries

(Estes dados foram obtidos na escola)

No ano de 1978 a escola passou a funcionar de prime $i$ ra a oitava séries e só no noturno nesse ano foram formadas 13 classes com alunos da quinta à oitava séries. A secretāria Apa recida Barbosa que chegou na escola em 1977 nos contou:

"A clientela no início era ruim, ela se formou na sua maioria pelos desistentes de outras escolas, existiam alunos favelados com baixo nivel de com portamento que se misturavam com os de classe mé dia com melhores condiçōes. O curso noturno não era reservado só para os que trabalhavam, nele es tudavam a grande maioria dos alunos de quinta a oitava séries, isto porque na escola só funciona vam duas quintas séries no vespertino".

A assistente de direção Profa. Etelvina continuou re latando sobre os alunos:

"O aproveitamento era baixo e o nümero de desisten tes era grande; os alunos além de estarem cansa dos do trabalho vinham para a escola a pé. Tudo isto contribuia para que não houvesse aprendizado. Naquela época o ūltimo ônibus subia até aque le morro às 17 h30, por ser o lugar perigoso.

Hoje as ônibus chegam até a escola embora a volta ocorra só até 21 hoo, por questão de segurança;os ônibus descem 'recolhe' até a praça com a Av. Pe ri Ronchetti e pegam passageiros a partir dai. No percurso mais perigoso eles param só para co nhecidos.

Quanto ao aproveitamento dos alunos continua bai xo e muito grande a evasão; cansados do trabalho, a maioria chega na segunda aula, perde as explí 
caçōes e não consegue mais acompanhar; além de se constatar que hoje o curso noturno rão esta ofere cendo coisa muito interessante para o aluno em ter mos präticos de proveito para a vida. Eles encon tram um ensino de pouca qualidade, professores de sestimulados, pouco incentivo para prosseguirem; $\underline{a}$ cabam desistindo ao constatarem o baixo aproveitamento obtido quando são divulgados os resultados das avaliações a partir do segundo bimestre.

A escola acaba sendo para muitos o local de rela cionamento social, nela eles encontram espaço para conversas sem perigo de assalto e agressões".

Em 1987 foi criado o ensino supletivo nesta escola (de primeira a quarta sēries), nos foi relatado que a procura é gran de embora a evasão e os problemas apresentados por estes alunos se assemelham aos do curso regular do lo grau noturno.

0 aumento populacional continuou ocorrendo naquela $\bar{a}$ rea e nos loteamentos vizinhos, a demanda de ensino se fazia sen tir quando foi criada a EEPG Guilherme de Almeida, pelo Decreto 9.631, do dia 31 de março de 1977, publicado no D.0. de 01.04.77.

Esta escola se localiza na Vila Amālia e começou a fun cionar no dia 04.06 .77 com 11 classes de primeira a quarta sé ries e um total de 390 alunos.

No ano de 1978 ela passou a funcionar de 1 a a 8 a séries com alunos remanejados de outras escolas que funcionavam com super-lotação; por determinação da Delegacia de Ensino.

Nesse ano ela estava constituida por 26 classes que vieram formadas da EEPSG Prof. Antonio José Leite e duas da EEPG Profa. Rita Bicudo Pereira e quinze classes foram criadas; 0 que dá para se concluir que grande parte da população estava sem escola. 
Um professor daquela época relatou:

"No início a escola não tinha secretaria nem funcio närios, os professores $\bar{e}$ quem faziam tudo inclusive limpeza do prédio nos fins de semana. Quanto ao aproveitamento escolar dos alunos das quintas sé ries $\bar{e}$ péssimo como também a evasão é grande; a par tir das sextas sēries a melhora é gradativa $e$ os alunos que atingem a sētima sērie na sua maioria conseguem terminar o curso.

A queda do aproveitamento é maior entre os alunos que trabalham: geralmente chegam sem alimentação ou só tomam um lanche; no final do expediente escolar chegam a dormir em aula; eles trabalham para se man ter e ajudar a jamilia. A evasão acentua-se entre os alunos trabalhadores."

A mesma ocorrência vai ser observada tambēm na vila Bela Vista que está muito prōxima das áreas que já foram anali sadas e a necessidade de escola estava evidente quando foi criada a EEPG Prof. Alfredo Gomes, pelo Decreto Lei 13.291/79. publicado pelo D.0. de 02.03.79.

Ela foi instalada no dia 12.02 .79 com quatro classes de alunos que vieram da EEPSG Prof. Antonio Josë Leite e doze classes foram criadas. Funcionaram nesse ano 16 classes de pri meira a oitava séries e foram matriculados 756 .

A clientela que essa escola assiste se caracteriza por ser de classe média baixa e a maioria é oriundo de famīlias que habitam a favela do Jardim Peri e a Odassy Mazzalli, nome da rua com que eles identificam tambēm a favela.

Uma professora e funcionārios da escola falaram sobre os alunos: 
"... eles apresentam todo tipo de necessidade; des de alimentar até carência afetiva; os aductos de suas familias trabalham, desde pequenos eles assu mem os compromissos domésticos, os maiores cuidam dos menores. A maioria dos alunos do noturno tra balha, vêm para escola cansados e nem sempre con seguem chegar no horārio além de estarem sem alí mentação. O aproveitamento é péssimo, eles vêm des motivados e pouco aproveitam. Hā queixas dos pro bessores que os alunos não têm material, não estu dam e quando se faz uma exigência maior eles fogem, pulam o muro e vão embora antes do término das aulas. Quando é feita a distribuição da meren da escolar nota-se inibição dos alunos maiores, $\underline{e}$ les pedem para os menores pegarem o lanche com salsicha ou sopa, isto porque os colegas caçoam e dizem que a merenda é 'mata fome'.

Eles se queixam da falta de variedade da merenda, embora a merendeira tente mudar o sabor colocando legumes e verduras na sopa.

E importante colocar que a evasão escolar $\bar{e}$ muito grande no curso noturno".

A escriturāria desta escola nos informou que os alu nos que a compõem na sua grande maioria são originārios do Nor deste; fato que ela constatou na apresentação de documentos por ocasião da matrîcula.

Depois de refletirmos sobre os depoimentos da clientela das escolas do Jardim Peri e das áreas vizinhas, gostaría mos de chamar a atenção dos órgãos competentes da necessidade de se pensar em outra escola para o ensino noturno; e para que ela exista com possibilidade de sucesso acreditamos que seja preciso planejar o seu funcionamento relacionado com o funcionamento do processo produtivo; uma vez que o grande empecilho 
para o sucesso escolar é a longa jornada de trabalho dos jovens.

0 nosso estudo se refere ao primeiro grau porque o Jar dim Peri não é assistido por escolas que possuem o segundo grau.

Com o intuito de mostrar o crescimento da população do Jardim Peri e āreas prōximas fizemos uma relação de cada uma das escolas que fazem parte deste estudo com o número de matrīculas e classes em março de 1988. (vide Fig.08 e Fotos de 03 a 10).

- EEPG Profa. Rita Bicudo Pereira

Março de 1988

Nūmero de classes: 49

Total de alunos: 1.712

Pré-escola - 2

Ciclo bāsico - 22

3르 sēries - 6

4 a sēries $\quad-4$

5 à séries - 6

6 a sēries - 4

7 a sēries - 3

8 a sēries - 2

49

- EEPG Profa. Elza Saraiva Monteiro

Março de 1988

Nūmero de classes: 51

Nümero de alunos: 1.748 
$\begin{array}{ll}\text { Ciclo básico } & -18 \\ 3 \stackrel{a}{-} \text { e } 4 \text { - sēries } & -11 \\ 5-\text { a } 8 \text { a sēries } & -16 \\ \text { Supletivo } & -4 \\ \text { Deficientes } & -\frac{2}{51}\end{array}$

EEPG Prof. Alfredo Gomes

Março de 1988

Nūmero de classes: 44

Total de alunos: 1.141

Pré-escola $\quad-12$

Ciclo bāsico - 11

3ㄹ e 4 sēries - 6

5 a a 8 a séries - 12

Supletivo

3

44

EEPG Guilherme de Almeida

Março de 1988

Nümero de classes: 60

Total de alunos: 2.050

Ciclo bāsico -20

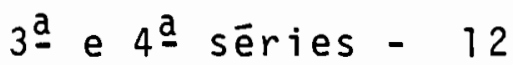

5 a sēries $\quad-10$

6- sēries $\quad-7$

7 a sēries $\quad-7$

8 a sēries - $\quad 4 \quad$ Fonte: Documentação das escolas 


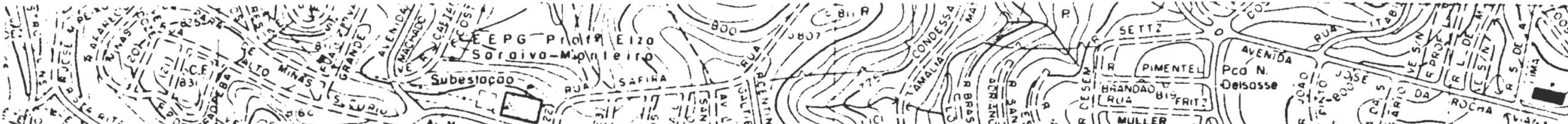
Sof II (1) (1)

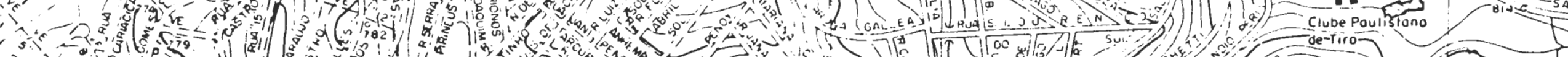

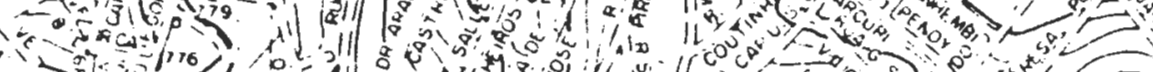

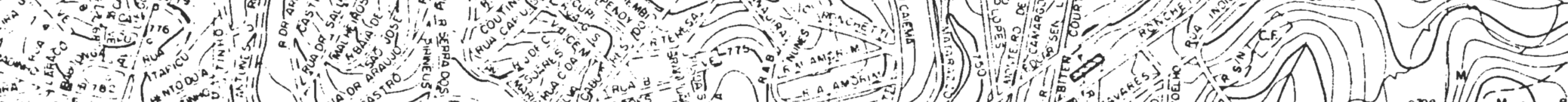

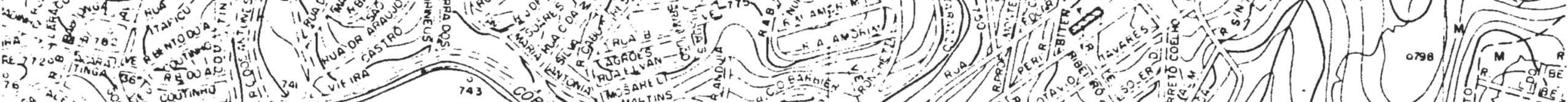
OFA \&Es

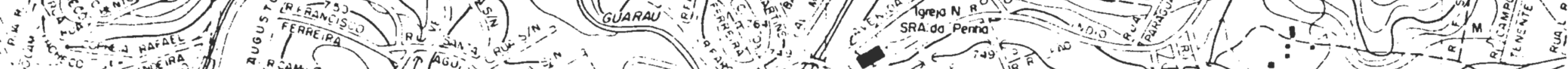
然 (1) (1) * (1) 动 =

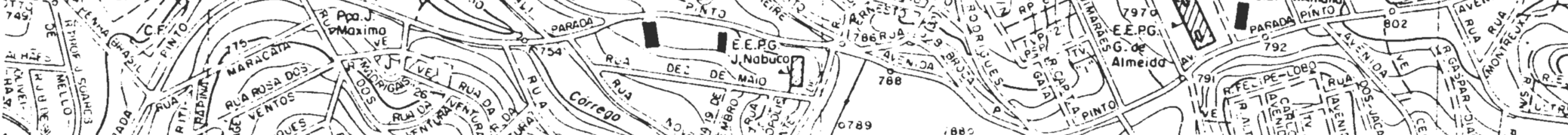
(1)

Fonte: EMPLASA - ATUALIZAÇAO - JANEIRO/1988 MUNICIPIO DE SÃO PAULO
esCOLAS FUnCIONANDO

FIGURA 8

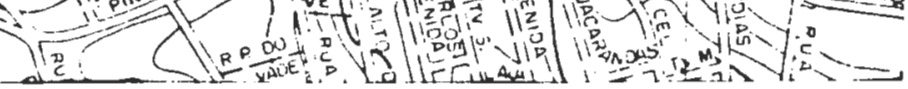
ESCALA

$0 \quad 150$ 300 
Contribuiram para o levantamento histórico das Escolas:

- Diva Therezinha Rosa

- Dayse Bertoli

- Ruth Trinca

- Luiza Mantellassi

- Josē Ademir Nardo

- Etelvina Rissuthi Fernandes

- Guiomar Cruz Antonio

- Nilza Aparecida Braga

- Maria Verönica da Silva

- José Alberto Gonçalves 
.66 .

\title{
2.4. Caracterização do menor
}

\begin{abstract}
"Considera-se, pela legislação brasileira, como me nor legalmente integrado no mercado de trabalho to das as pessoas maiores de 14 anos e menores de 18 anos que executam trabalho remunerado em empregos registrados em carteiras de trabalho".
\end{abstract}

Menor corresponde ao termo legal que define toda a po pulação abaixo de 18 anos de idade; perīodo da vida do homem re servado para sua formação e socialização; que deverá ocorrer de maneira informal no grupo familiar e formal na escola. Partindo - se do pressuposto que os encargos para o progresso da sociedade é incumbēncia do jovem de hoje no dia de amanhã; cabe a esta sociedade a responsabilidade de formā-lo, instruī-lo a fim de que ele tenha plena condição de assumir na idade adulta os en cargos para com a sua famîlia como tambēm contribua no avanço da coletividade.

A ideologia apontada não è o que vem ocorrendo nas ū]. timas décadas na sociedade brasileira.

O desenvolvimento capitalista em nosso pais constitui - elemento capaz de provocar profundas transformações em todaso ciedade nos dias atuais.

A familia tem sofrido diretamente o impacto das trans formações, principalmente no que diz respeito a remuneração da força de trabalho.

0 custo de vida se torna cada dia mais elevado e a re muneração recebida pelo chefe da famîlia não tem sido suficiente para cobrir os gastos; isto tem ocasionado o ingresso na for 
ça de trabalho de todos os elementos da casa desde a mais ten ra idade.

Vemos apontadas as precárias condições de vida como fator determinante da entrada do menor no mercado de trabalho, acarretando para ele sérias consequencias na sua vida atual e futura.

Desde cedo o jovem se depara com o trabalho e o com promisso escolar, nem sempre as duas atividades se conciliam a carretando sempre prejuizo de uma; a atividade profissional $\underline{\text { e }}$ xercida de dia obriga o aluno a estudar à noite, o desgaste casionado pelo trabalho juntamente com as dificuldades de con dução alēm da alimentar culminam geralmente com a diminuição do aproveitamento, desestimulo e, na maioria das vezes, com a de sistēncia da escola.

Constata-se que os excluídos da escola fazem parte da população de mais baixos rendimentos.

Como observaram Fukui, Sampaio e Brioschi (1980:1,2), no trabalho que elaboraram "A Questão do Trabalho Infantil na Grande Imprensa Paulista na Década de 70" são vārios os motivos da desistēncia escolar:

"... pelo fato da escola exigir da clientela um in vestimento considerāvel em material e uniforme, ve rificando-se ai um dos fatores da seletividade que caracteriza a organização escolar. No entanto, a valorização expressa do aprender a ler, escrever e contar, associada às precārias condições de vida faz com que, em primeiro lugar muitas crianças ten tem associar algum tipo de atividade remunerada à freqlência à escola. Essa conjugação tem-se mos- 
trado inviāvel de ser mantida por tempo prolongado ocasionando o processo de exclusão nos primeiros a nos de escolaridade".

Esta realidade tenho observado no Jardim Peri, onde leciono. Nossa escola no início do ano está com as classes lo tadas. Quando são efetuadas as primeiras avaliações e constata dos os resultados, a frequencia começa a diminuir. Este proces so vai se acentuando gradativamente, ao atingir novembro essa redução chega atingir cifras de 60 a $70 \%$; embora esta ocorrēncia seja mais acentuada no período noturno. Esses alunos têm necessidade de conciliar o trabalho com a escola, cansados no fim do dia ainda enfrentam transporte, muitos vēm direto para a escola por qulestão de tempo e na maioria das vezes sem al $\underline{\mathbf{i}}$ mentação. Ao constatarem o baixo rendimento se desestimulam e abandonam a escola.

Segundo Paulo Freire $(1987: 12,13)$ o trabalho a ser feito junto ao menor trabalhador é de cunho politico, ideológi co e pedagōgico. Ele coloca que:

\footnotetext{
"... os meninos, no fundo homens antecipados pela dureza da luta, precisam chegar a entender, em termos criticos, a razão de ser de sua luta; pre cisam entender o seu trabalho, precisam entender o próprio jogo como expressão da vida deles".
}

Is to porque:

"... Não hā esperança da justiça social. Por isso: sō na luta se espera com esperança". 


\subsection{Caracterizaçäo da bamilia}

0 Jardim Peri é constituido na sua maioria por famí lias de classe média baixa e baixa. Antes de 1962 a população se caracterizava por serem paulistanos e paulistas e sua maio ria era de operārios.

Depoimento de moradores antigos do lugar me revelaram que a expansão da ārea ocorreu a partir da década de 1960 com a chegada de inúmeras famỉitias mineiras e nordestinas muito po bres; foi a partir da $\vec{i}$ que começaram a surgir naquele loteamen to as primeiras favelas.

O meu interesse em estudar os alunos me levou a um $\underline{a}$ profundamento maior atingindo os familiares com o intuito de tentar encontrar explicações para certas atitudes de comportamento dos meus alunos. Atravēs dos questionārios aplicados ob tive um universo de informaçães sobre 1.793 pessoas incluindo os familiares dos entrevistados. As questões feitas têm por ob jetivo investigar a origem dos alunos através de perguntas so bre o local de nascimento das pessoas, o nível de escolaridade delas, tipo de trabalho desempenhado, salärio, de onde elas vie ram para São Paulo e o tempo de moradia que elas possuem no Jar dim Peri. Das 1793 pessoas que chegaram em São Paulo 846 sendo a maioria mineiros $21,04 \%$ seguidos de $18,67 \%$ baianos, $18,20 \%$ pa ranaenses, $15,24 \%$ paulistas, diminuindo a proporçăo de pessoas que vieram dos outros estados do Nordeste, seguidos por um nū mero ainda menor de brasileiros dos outros estados que tiveram interesse em migrar para São Paulo. A vinda dos estrangeiros nessa época é pouco significativa, prevalecendo maior interes- 
se dos portugueses que vieram $1,41 \%$ seguidos de $0,84 \%$ de italia nos, $0,48 \%$ de bolivianos, $0,24 \%$ espanhōis e 1 alemão correspon dendo a $0,12 \%$ do total de migrantes estrangeiros. (vide Fig. 09).

\subsection{Migração e trabalho}

Os dados levantados na pesquisa vão confirmar a his tōria da migração brasileira quando revelam que a mobilidade in ter-regional foi mais intensa com a população mineira e nordes tina para as grandes cidades do sudeste.

A mobilidade entre os Estados brasileiros se tornou mais intensa no Governo Kubitschek com a realização do Programa de Metas, que visava transformar a estrutura econōmica do Paĩs, pela criação da indústria de base e a reformulação das condições reais de interdependēncia com o capitalismo mundial $(1979: 150)$.

Era objetivo desse programa abolir os pontos de es trangulamento da economia e expandir a indūstria de base.

O governo tinha por finalidade criar condições econō micas, financeiras, sociais e politicas para o florescimentoda livre iniciativa, cujo interesse era atrair empresārios estran geiros com tecnologia e capital.

Fèz parte desse plano a construção e reaparelhamento de ferrovias, a construção e pavimentação de rodovias entre $\underline{e}$ las Belém-Brasīila, tornando os Estados brasileiros mais próxí mos atravēs da comunicação. Tais fatos contribuiram para que populações oriundas de āreas rurais e urbanas de vārios Estados 
DE ONDE VIERAM PARA SAO PAULO FAMILIARES E ALUNOS ENTREVISTADOS

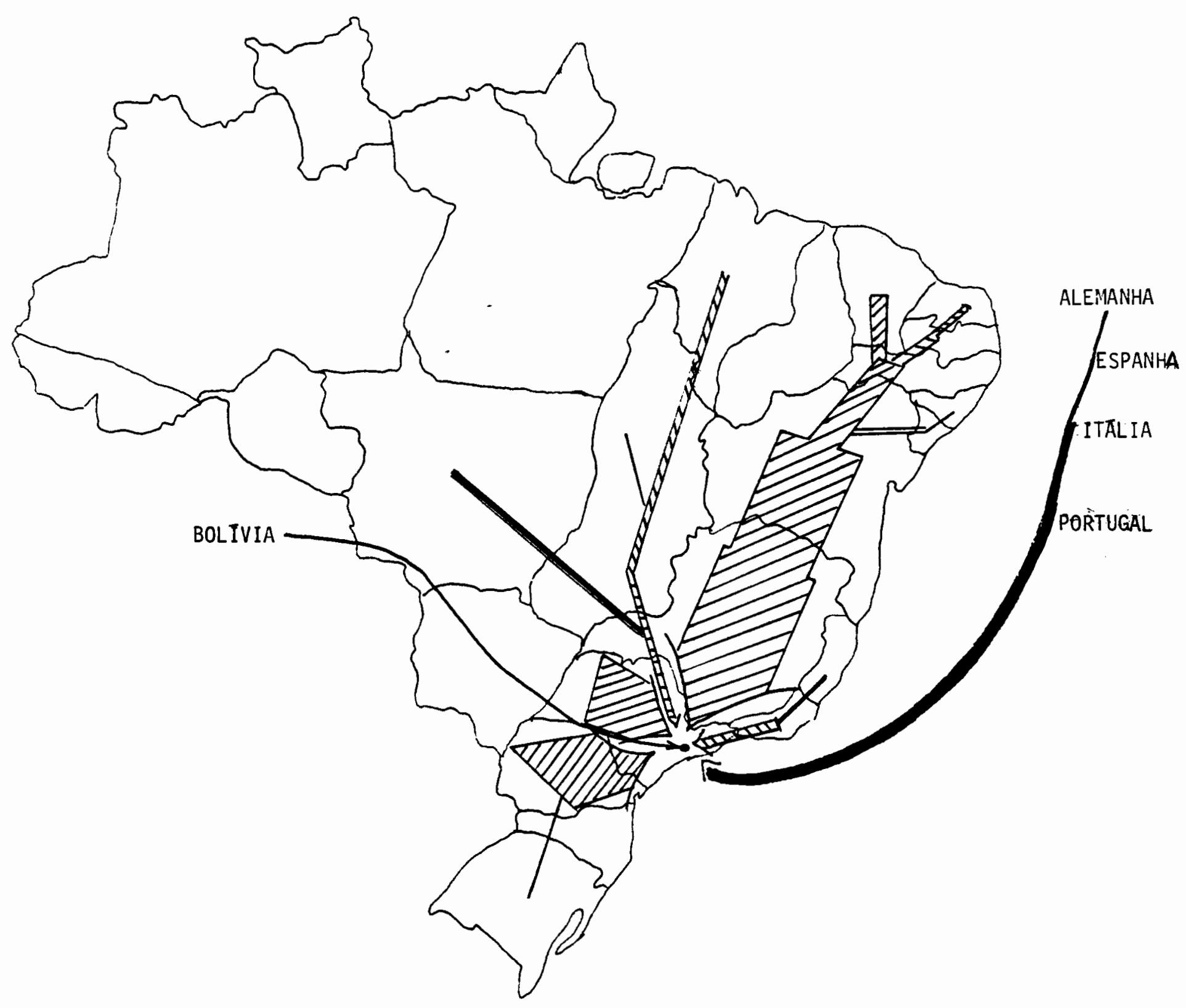

FIGURA 09

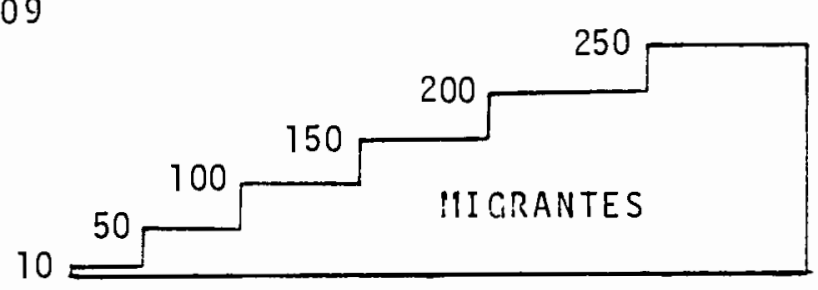


brasileiros se dirigissem para o sudeste principalmente para São Paulo, onde foi instalado o maior parque industrial do Brá sil. As populações se sentiam atraídas pelas vantagens reais ou supostas que a Metrópole Paulista podia lhes oferecer.

Esta manifestação dinâmica e espontānea vai contrị buir para a organização do espaço da nova região e ele só vai ser entendido como resultado de uma relação social ou seja o espaço produzido socialmente.

o Jardim Peri mostra essa realidade e o crescimento dele a partir da década de 60 em função da expansão industrial da cidade constata a chegada de inümeras famīlias no local in teressadas em emprego oferecido na cidade.

0 fato exposto nos mostra que houve em São Paulo um aumento muito grande de serviços no setor terciārio, que produz a concentração humana; vemos que a atividade comercial alēm de ter ampliado se especializou, o mesmo aconteceu com a ativi dade financeira, a rede de ensino se estendeu bastante, apare cendo ao seu lado uma variedade de cursos profissionalizantes; os serviços pessoais tambēm se ampliaram como os hotéis, salões de beleza, além do amplo leque de empregos originados pela in dūstria automobilistica e os serviços semi domésticos em pré dios.

Buscando as origens da clientela estudantil procurei indagar sobre o lugar de nascimento dos pais e avós inclusive daqueles que nunca vieram para São Paulo ou mesmo daqueles que já estiveram aqui e retornaram ao lugar de nascimento.

Neste universo obtive informações de 1.793 pessoas 
incluindo os familiares dos entrevistados. As questões feitas alēm de investigar o local de origem das pessoas questionou tam bēm o nível de escolaridade, tipo de trabalho desempenhado, sa lário, de onde vieram para são Pauto e o tempo de moradia no Jardim Peri.

0 nūmero de pais e avōs dos entrevistados com que ob tivemos informações somam 1.052 pessoas; constatamos que a gran de maioria nasceu em Minas Gerais e constitui $22,44 \%$ convēm es clarecer que de $11,21 \%$ desses individuos não foi informado 10 cal de nascimento porque os alunos desconheciam. Vamos encontrar em seguida a Bahia tendo uma porcentagem de $17,50 \%$ só a partir daî aparece São Paulo, capital com $11,40 \%$ de representan tes que habitam hoje aquele loteamento, em seguida surge São Paulo interior com $10,74 \%$; dos outros Estados do Brasil a por centagem é pequena. (vide Figura 10).

E importante mencionar que existem avós e pais com $\underline{0}$ rigem em paises da Europa como: Portugal, Itālia, Espanha, Hun gria e Alemanha; existe tambēm representantes do Japão e da Bo lívia embora de todos eles a porcentagem de representantes $\bar{e}$ pe quena.

Se tentarmos agrupar os migrantes dos vārios Estados do Nordeste que se fixaram no Jardim Peri constatamos que eles correspondem a $34,41 \%$ superando a porcentagem de mineiros que tambēm para là se dirigiram.

Esse movimento de migração interna define um processo social resultante de mudanças de um determinado lugar que provocam o deslocamento horizontal de pessoas de todas as clas ses sociais, que, por razões diversas saem do lugar de origem para outro. 
LOCAL DE NASCIMENTO DOS PAIS E AVOS DOS ENTREVISTADOS (RELACIONADOS)

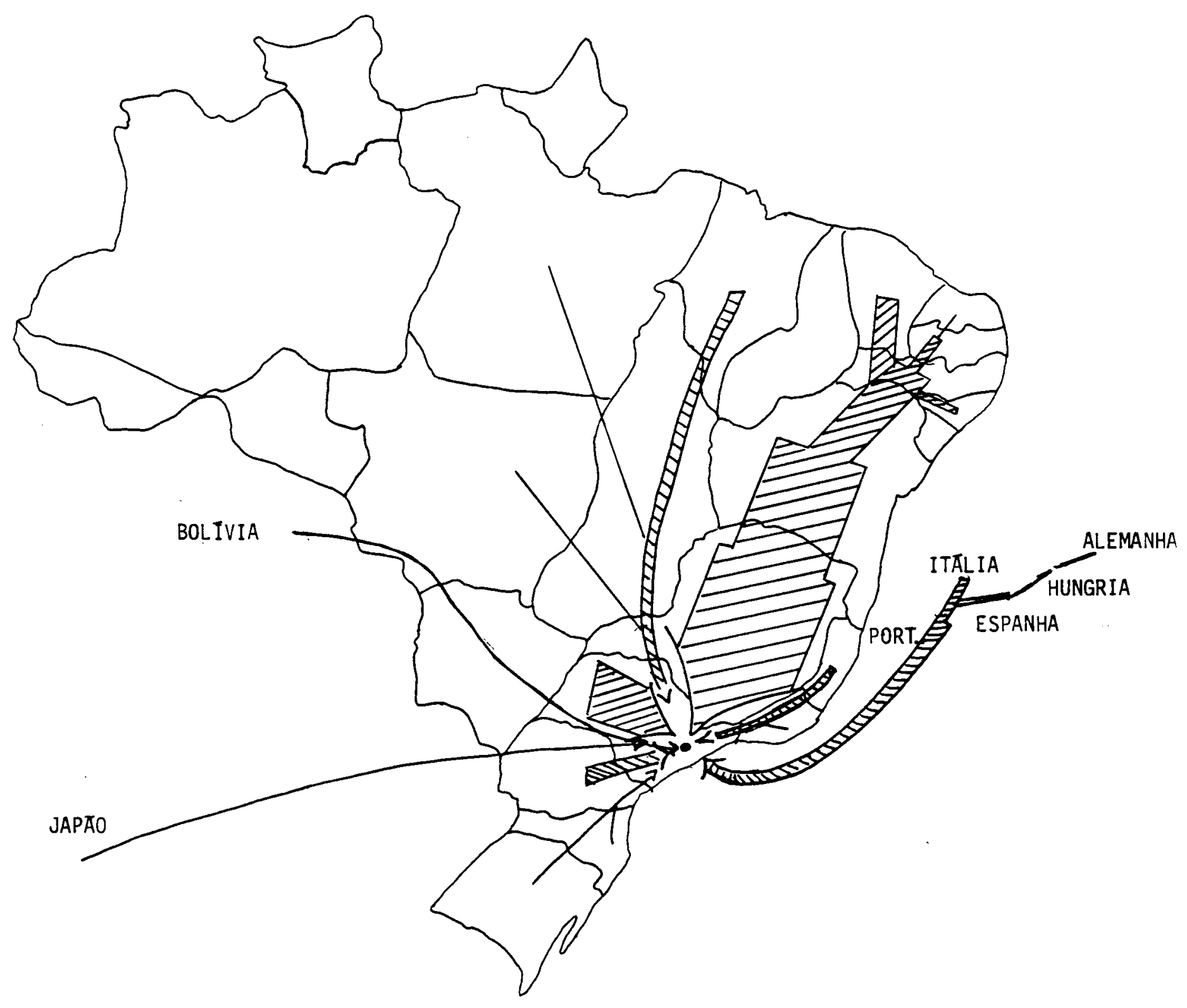

FIGURA 10

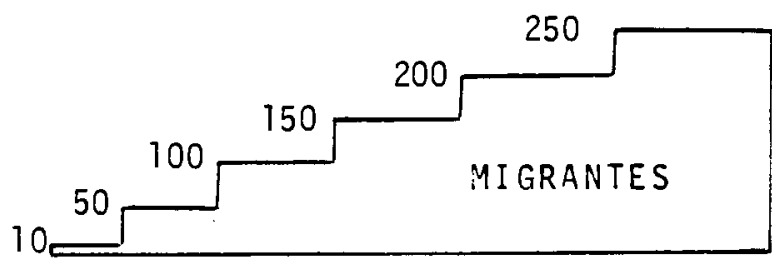

$\underbrace{0 \quad 250 \quad 500 \quad 750}_{\mathrm{km}}$ 
Esse fenômeno nasce e se desenvolve num contexto so cial historicamente determinado.

Segundo nos mostra Paul Singer (1980:129):

"... os vastos fluxos migratōrios que cruzam o territōrio brasileiro, que, de acordo com o censo de 1970, englobavam mais de $30 \mathrm{mi}$ lhōes de pessoas numa população de pouco mais de 93 milhões, $\bar{e}$ fácil ver que o exército industrial de reserva atinge dimensōes formidāveis no Brasil, $j \bar{a}$,que a grande maioria dos migrantes se desloca à procura de trabalho".

$\mathrm{Na}$ figura que envolve todos os familiares incluindo os irmãos, pode-se constatar maior número de nascimentos na capital de São Paulo, corres pondendo a $30,46 \%$ o que revela o nascimento de vārios filhos apōs a fixação da famîlia na cidade de São Paulo. Minas Gerais continua aparecendo com apreciāvel número de nascimentos e correspondem a $17,17 \%$ em seguida aparece a Bahia com $13,77 \%$, São Paulo - interior com $7,80 \%$, Pernambuco com $5,57 \%$, Para nā com $5,29 \%$. Temos familiares dos entrevistados que nasceram em outros esta dos da federação em pequena porcentagem. E mīnima a representação de outros paīses e corresponde aos jā mencionados.

As informações que relatam a local de nascimento dos alunos mostra que $54,86 \%$ deles são de São Paulo - capital, vieram do interior de São Pau $1010,77 \%$; constata-se que a Bahia é o Estado que segue com $9,29 \%$, Minas Gerais com $7,52 \%$, Paranā com $5,3 \%$ dos outros estados da federação o nūmero de nascimento é pequeno. (ver Tabela 01 ).

Somando-se os alunos nordestinos eles correspondem a 18,14\%, para esta forma de avaliação eles ocupam o segundo lugar de procedēncia.

A comparação objetiva verificar atē que ponto o número de pessoas que constituem os moradores do Jardim Peri são procedentes de outros municí pios, como também o período em que eles se fixaram no bairro.

Os familiares dos alunos do Jardim Peri começaram a se estabelecer naquele local há quase trinta anos, isto ocorreu de forma gradativa e hoje aquele loteamento encontra-se po 
TABELA 01

LOCAL DE NASCIMENTO DOS ALUNOS

\begin{tabular}{|c|c|c|c|c|c|c|}
\hline ESTADO & $\begin{array}{c}\text { RITA } \\
\text { BICUDO }\end{array}$ & $\begin{array}{c}\text { ELZA } \\
\text { SARAIVA }\end{array}$ & $\begin{array}{l}\text { GUILHERME } \\
\text { DE ALMEIDA }\end{array}$ & $\begin{array}{l}\text { ALFREDO } \\
\text { GOMES }\end{array}$ & $\begin{array}{l}\text { TOTAL } \\
\text { GERAL }\end{array}$ & $\%$ \\
\hline São Paulo-capital & 29 & 30 & 34 & 31 & 124 & 54,86 \\
\hline São Paulo-interior & 04 & 09 & 05 & 05 & 23 & 10,17 \\
\hline Bahia & 07 & 08 & 05 & 01 & 21 & 9,29 \\
\hline Minas Gerais & 08 & 04 & 03 & 02 & 17 & 7,52 \\
\hline Paranā & 03 & 07 & 01 & 01 & 12 & 5,30 \\
\hline Pernambuco & 02 & 02 & 02 & 02 & 08 & 3,53 \\
\hline Cearāa & 04 & 01 & - & - & 05 & 2,21 \\
\hline Parā & - & 03 & - & - & 03 & 1,32 \\
\hline T. Acre & - & 02 & - & - & 02 & 0,89 \\
\hline Distrito Federal & - & 02 & - & - & 02 & 0,89 \\
\hline Rio Grande do Norte & - & - & 02 & - & 02 & 0,89 \\
\hline Maranhão & 01 & 01 & - & - & 02 & 0,89 \\
\hline Paraỉba & 01 & - & - & 01 & 02 & 0,89 \\
\hline Sergipe & - & 01 & - & - & 01 & 0,45 \\
\hline Rio de Janeiro & - & 01 & - & - & 01 & 0,45 \\
\hline Espïrito Santo & - & - & 01 & - & 01 & 0,45 \\
\hline TOTAL & 59 & 71 & 53 & 43 & 226 & 100 \\
\hline
\end{tabular}

Fonte: Questionārios aplicados - Outubro/1985 
voado; $31,19 \%$ informaram que estão no Jardim Peri hă mais de de zesseis anos, $15,59 \%$ moram lá entre oito e dez anos. Existe um equilibrio entre os que se estabeleceram na ārea no perĩodo de:

8 a 13 anos - 13,53\%
14 a 16 anos - 13,36\%
5 a 7 anos - 13,35\%

E pequena a porcentagem dos individuos que chegaram re centemente.

Comprovando este fenōmeno Paul Israel Singer nos mos tra em seu estudo (1975:13), que:

"O proletariado industrial, constituido pelos assala riados do setor capitalista da economia, tem cresci do fortemente, como resultado da aceleração do rit mo de acumulação do capital e da expansão da força de trabalho urbana, que resulta tanto das migrações internas como do crescimento vegetativo da população das cidades.

Entre 1950 e 1970, a força de trabalho engajada em atividades não agricolas aumentou de $117 \%$, passando de 7,2 para 16,5 milhões de pessoas, mas 0 nūmero de assalariados nesta atividade cresceu - 172\% nes te período, passando de 4,8 para 12,9 milhöes".

Considerando-se que a grande maioria dos migrantes vieram do local de nascimento direto para a cidale de São Pau 10, convém mencionar que outros fatores levaram uma minoria que corresponde a $4,51 \%$ daqueles que aqui estão, tentar se estabelecer em outro lugar anterior ao atual, $1,78 \%$ deles sairam de Minas Gerais, foram para o Paraná e posteriormente se dirigiram para a cidade de São Paulo. Em alguns casos resultou no estabe 
cimento de migrantes no interior de São Paulo, Rio Grande do Sul, Minas Gerais, Espirito Santo, Bahia: A procedencia dessas pessoas ocorreu de vários pontos do pā́s para os locais indica dos e posteriormente eles se fixaram na cidade de São Paulo.

0 estudo efetuado sobre as condições sōcio-econōmicas das familias envolvidas neste trabalho oferece elementos que esclarecem os motivos que ocasionam a entrada do menor no mer cado de trabalho como forma de sobrevivência da familia.

Através de levantamento feito ficou constatado que a formação cultural das famīlias do aluno do Jardimperi se ca racteriza por terem escolarização inferior. Os dados gerais de instrução vem confirmar o quanto essas famỉlias possuem padrões modestos na sociedade, via de regra os mais cultos são os que vão conseguir melhores condições no grupo. A renda familiar a ferida por elas é pequena para um número relativamente grande de pessoas que a compõem; este quadro define a necessidade de trabalho dos filhos para complementar os gastos.

Informações fornecidas por eles mostram que $21,57 \%$ são analfabetos, $14,82 \%$ chegaram a 2 a série, $29,39 \%$ corresponde aos que conseguiram atingir a 4 ạ sērie, $10,41 \%$ concluiram a $8 \stackrel{\text { a }}{\text { sé }}$ rie. Só $6,77 \%$ chegaram ao 20 grau e para o nî̉el superior é in significante os representantes - 0,30\%. Para esse resultado fo ram utilizados 1.565 informações, è importante esclarecer que - nỉvel maior de instrução pertence às pessoas do sexo mascul $\underline{i}$ no, o preconceito ao pouco valor da necessidade de instrução para as mulheres fica claro neste levantamento. (Tabelas 02 a 06).

Esta realidade vai se refletir nas funções de traba Tho desempenhada por eles, predominando os empregados em servi 
TABELA 02

TOTAL GERAL POR SERIE - ESCOLARIDADE DA FAMILIA

\begin{tabular}{|c|c|c|c|c|c|c|c|c|c|c|c|c|}
\hline \multirow[b]{2}{*}{ ESCOLARIDADE } & \multicolumn{2}{|c|}{ 5ó sērie } & \multicolumn{2}{|c|}{ 6ㄹ sērie } & \multicolumn{2}{|c|}{ 7̣ sērie } & \multicolumn{2}{|c|}{ 8ª sērie } & \multicolumn{2}{|c|}{ TOTAL } & \multicolumn{2}{|c|}{ TOTAL GERAL } \\
\hline & $M$ & $\mathrm{~F}$ & $M$ & $F$ & $M$ & $\mathrm{~F}$ & $M$ & $F$ & M & $F$ & $a b$ & $\%$ \\
\hline Anal fabe to & 37 & 47 & $4 C$ & 45 & 35 & 33 & 44 & 56 & 156 & 181 & 337 & 21,57 \\
\hline $1 \underline{\mathrm{a}}$ a $2^{\mathrm{a}}-$ série & 15 & 19 & 30 & 18 & 27 & 46 & 32 & 45 & 104 & 128 & 232 & 14,82 \\
\hline 3ㅁa $4^{\underline{a}}$ sērie & 50 & 49 & 34 & 44 & 75 & 77 & 82 & 49 & 241 & 219 & 460 & 29,39 \\
\hline 5ㅁ a 6으 sērie & 48 & 34 & 32 & 23 & 34 & 26 & 42 & 23 & 156 & 106 & 262 & 16,74 \\
\hline $7^{\mathrm{a}}$ a $8^{\underline{a}}$ sērie & 11 & 12 & 19 & 22 & 28 & 20 & 25 & 26 & 83 & 80 & 163 & 10,41 \\
\hline 20 grau & 04 & 08 & 06 & 10 & 19 & 18 & 20 & 21 & 49 & 57 & 106 & 6,77 \\
\hline Superior & - & - & - & 01 & - & - & 02 & 02 & 02 & 03 & 05 & 0,30 \\
\hline Total & 165 & 169 & 161 & 163 & 218 & 220 & 247 & 222 & 791 & 774 & 1565 & 100 \\
\hline
\end{tabular}

Fonte: Questionārios aplicados - Outubro/85 
TABELA 03

EEPG PROFa. RITA BICUDO PEREIRA - ESCOLARIDADE DA FAMILIA

\begin{tabular}{|c|c|c|c|c|c|c|c|c|c|c|c|c|}
\hline \multirow[b]{3}{*}{ ESCOLARIDADE } & \multirow{2}{*}{\multicolumn{2}{|c|}{$5^{\mathrm{a}}$ sērie }} & \multirow{2}{*}{\multicolumn{2}{|c|}{ 6- sērie }} & \multirow{2}{*}{\multicolumn{2}{|c|}{$7^{\mathrm{a}}$ sērie }} & \multirow{2}{*}{\multicolumn{2}{|c|}{ 8a sērie }} & \multicolumn{4}{|c|}{ TOTAL } \\
\hline & & & & & & & & & \multicolumn{2}{|c|}{$M$} & \multicolumn{2}{|c|}{$F$} \\
\hline & $M$ & $F$ & M & $F$ & M & $F$ & M & $F$ & $\overline{a b}$ & $\%$ & $a b$ & $\%$ \\
\hline Analfabeto & 08 & 15 & 12 & 14 & 09 & 10 & 18 & 20 & 47 & 23,74 & 59 & 26,97 \\
\hline $1 \underline{\mathrm{a}}$ a $2^{\mathrm{a}}$ série & 02 & 10 & 07 & 03 & 03 & 14 & 06 & 19 & 18 & 9,09 & 46 & 21,00 \\
\hline $3-\underline{a}$ e $4 \underline{a}$ série & 10 & 11 & 07 & 07 & 21 & 19 & 30 & 17 & 68 & 34,34 & 54 & 24,66 \\
\hline $5-$ e $6-$ série & 09 & 05 & 01 & 07 & 08 & 09 & 15 & 06 & 33 & 16,67 & 27 & 12,33 \\
\hline $7^{\mathrm{a}} \underline{\mathrm{a}}$ e $8^{\underline{a}}$ série & - & 02 & 06 & 02 & 06 & 07 & 09 & 12 & 21 & 10,61 & 23 & 10,50 \\
\hline 29 grau & - & - & 03 & - & 06 & 04 & 02 & 06 & 11 & 5,55 & 10 & 4,57 \\
\hline Superior & - & - & - & - & - & - & - & - & - & - & - & - \\
\hline Total & 29 & 43 & 36 & 33 & 53 & 63 & 80 & 80 & 198 & 100 & 219 & 100 \\
\hline
\end{tabular}

Fonte: Questionários aplicados - Outubro/85 
TABELA 04

EEPG PROFa. ELZA SARAIVA MONTEIRO-ESCOLARIDADE DA FAMILIA

\begin{tabular}{|c|c|c|c|c|c|c|c|c|c|c|c|c|}
\hline \multirow[b]{3}{*}{ ESCOLARIDADE } & \multirow{2}{*}{\multicolumn{2}{|c|}{ 5- sērie }} & \multirow{2}{*}{\multicolumn{2}{|c|}{ 6- sērie }} & \multirow{2}{*}{\multicolumn{2}{|c|}{$7^{\mathrm{a}}$ sērie }} & \multirow{2}{*}{\multicolumn{2}{|c|}{ 8- sērie }} & \multicolumn{4}{|c|}{ TOTAL } \\
\hline & & & & & & & & & \multicolumn{2}{|c|}{$M$} & \multicolumn{2}{|c|}{$F$} \\
\hline & M & $F$ & $M$ & $\mathrm{~F}$ & $M$ & $F$ & M & $\mathrm{F}$ & $\overline{a b}$ & $\%$ & $a b$ & $\%$ \\
\hline Analfabe to & 12 & 15 & 20 & 19 & 18 & 14 & 23 & 29 & 73 & 26,94 & 77 & 33,33 \\
\hline $1 \stackrel{\mathrm{a}}{\mathrm{a}}$ a $2^{\mathrm{a}}$ série & 05 & 02 & 10 & 04 & 18 & 21 & 17 & 11 & 50 & 18,45 & 38 & 16,45 \\
\hline 2- a 4- sērie & 09 & 06 & 09 & 11 & 24 & 26 & 21 & 16 & 63 & 23,24 & 59 & 25,54 \\
\hline 5- a 6- série & 06 & 05 & 10 & 06 & 17 & 05 & 12 & 07 & 45 & 6,60 & 23 & 9,96 \\
\hline $7^{\mathrm{a}}$ a $8^{\mathrm{a}}$ sērie & 01 & 03 & 05 & 02 & 11 & 08 & 06 & 09 & 23 & 8,49 & 22 & 9,52 \\
\hline 20 grau & - & - & 01 & 01 & 08 & 03 & 06 & 08 & 15 & 5,54 & 12 & 5,20 \\
\hline Superior & - & - & - & - & - & - & 02 & - & 02 & 0,74 & - & - \\
\hline Total & 33 & 31 & 55 & 43 & 96 & 77 & 87 & 80 & 271 & 100 & 231 & 100 \\
\hline
\end{tabular}

Fonte: Questionārios aplicados - Outubro/85 


\begin{tabular}{|c|c|c|c|c|c|c|c|c|c|c|c|c|}
\hline \multirow[b]{3}{*}{ ESCOLARIDADE } & \multirow{2}{*}{\multicolumn{2}{|c|}{ 5a sērie }} & \multirow{2}{*}{\multicolumn{2}{|c|}{ 6- sērie }} & \multirow{2}{*}{\multicolumn{2}{|c|}{$7^{\mathrm{a}}$ - sērie }} & \multirow{2}{*}{\multicolumn{2}{|c|}{ 8a sērie }} & \multicolumn{4}{|c|}{ TOTAL } \\
\hline & & & & & & & & & & 1 & & $\bar{F}$ \\
\hline & $M$ & $\mathrm{~F}$ & M & $\mathrm{F}$ & M & $F$ & M & $\mathrm{F}$ & $a b$ & $\%$ & $a b$ & $\%$ \\
\hline Anal fabe to & 06 & 09 & 06 & 04 & 07 & 08 & - & 01 & 19 & 10,38 & 22 & 12,57 \\
\hline 1a a $2^{\mathrm{a}}$ sērie & 02 & 03 & 08 & 04 & 04 & 05 & 07 & 12 & 21 & 11,48 & 24 & 13,72 \\
\hline $3 \underline{a}$ a $4 \underline{a}$ série & 23 & 17 & 08 & 10 & 20 & 23 & 15 & 07 & 66 & 36,07 & 57 & 32,57 \\
\hline 5- a 6 a série & 12 & 17 & 14 & 03 & 07 & 10 & 06 & 05 & 39 & 21,31 & 35 & 20,00 \\
\hline $7^{\mathrm{a}} \underline{\mathrm{a}}$ a $8^{\underline{a}}$ sērie & 08 & 05 & 06 & 06 & 06 & 03 & 04 & 02 & 24 & 13,11 & 16 & 9,14 \\
\hline 20 grau & - & 01 & 01 & 05 & 03 & 08 & 09 & 05 & 13 & 7,10 & 19 & 10,86 \\
\hline Superior & - & - & - & - & - & - & 01 & 02 & 01 & 0,55 & 02 & 1,14 \\
\hline Total & 51 & 52 & 43 & 32 & 47 & 57 & 42 & 34 & 783 & 100 & 175 & 100 \\
\hline
\end{tabular}

Fonte: Questionārios aplicados - outubro/85 
TABELA 06

EEPG PROF. ALFREDO GOMES - ESCOLARIDADE DA FAMILIA

\begin{tabular}{|c|c|c|c|c|c|c|c|c|c|c|c|c|}
\hline \multirow[b]{3}{*}{ ESCOLARIDADE } & \multirow{2}{*}{\multicolumn{2}{|c|}{ 5- sērie }} & \multirow{2}{*}{\multicolumn{2}{|c|}{ 6- sērie }} & \multirow{2}{*}{\multicolumn{2}{|c|}{$7^{\mathrm{a}}$ sērie }} & \multirow{2}{*}{\multicolumn{2}{|c|}{8 a sērie }} & \multicolumn{4}{|c|}{ TOTAL } \\
\hline & & & & & & & & & & $M$ & & $F$ \\
\hline & 11 & $F$ & $M$ & $F$ & $M$ & $F$ & $\bar{M}$ & $F$ & $a b$ & $\%$ & $a b$ & $\%$ \\
\hline Analfabeto & 11 & 08 & 02 & 03 & 01 & 01 & 03 & 06 & 17 & 14,44 & 18 & 12,50 \\
\hline $1 \underline{\mathrm{a}}$ a $2 \stackrel{\mathrm{a}}{-}$ sērie & 06 & 04 & 05 & 07 & 02 & 06 & 02 & 03 & 15 & 12,71 & 20 & 13,89 \\
\hline 3- a 4- sērie & 08 & 15 & 10 & 16 & 10 & 09 & 08 & 09 & 36 & 30,51 & 49 & 34,03 \\
\hline 5- a $6-$ sērie & 09 & 07 & 07 & 07 & 02 & 02 & 05 & 05 & 23 & 19,49 & 21 & 14,58 \\
\hline $7 \underline{\mathrm{a}}$ a $8 \stackrel{\mathrm{a}}{-}$ sērie & 02 & 02 & 02 & 12 & 05 & 02 & 07 & 03 & 16 & 13,56 & 19 & 13,19 \\
\hline 20 grau & 04 & 07 & 01 & 04 & 02 & 03 & 04 & 02 & 11 & 9,32 & 16 & 11,12 \\
\hline Superior & - & - & - & 01 & - & - & - & - & - & - & 01 & 0,69 \\
\hline Total & 40 & 43 & 27 & 50 & 22 & 23 & 29 & 28 & 118 & 100 & 144 & 100 \\
\hline
\end{tabular}

Fonte: Questionārios aplicados - outubro/85 
ços domésticos, pedreiros, auxiliares de costura, agricultura, marcineiros, motoristas, guarda-noturnos, ajudantes-geral e ou tras funções que aparecem em menor proporção.

A ordem de trabalho desempenhado pelos familiares dos alunos foi descrita em forma decrescente do número de pessoas que as desempenham.

Considerando-se que o grau de instrução $s \in j a$ impor tante para a reprodução da classe e que o nível de esclarecimen to da clientela contribui para obtenção dos melhores trabalhos, o grau de conhecimento dos familiares desses alunos mostra o baixo valor do seu trabalho na sociedade.

Comprovando esta realidade nos mostra Cortēs em seu trabalho $(1986: 181)$ :

"... a baixa escolaridade do grupo concorre e refor ça, dentro de certos limites, a desvalorização de sua força-de-trabalho no mercado e, desta forma, im plica na manutenção da produção e reprodução das condições de vida em situação de carência que, por sua vez, impõem, a necessidade de trabalho suplemen tar, o do menor inclusive".

A partir de observação efetuada em dados fornecidos por eles sobre a renda mensal da famīila, é possīvel perceber que no conjunto das familias consideradas o montante percebido por elas é insuficiente para manutenção de todos os membros da casa, mesmo em suas necessidades básicas.

Motivo pelo qual eles se vēm obrigados a lançar no mercado de trabalho todos os elementos da casa que apresentam o mĩnimo de condição de fazê-lo. 
A tabela demonstrativa de renda familiar deixa claro que $14,68 \%$ delas sobrevivem com renda entre trēs e quatro salá rios minimos, $14,18 \%$ recebem de seis a sete salários e $12,42 \%$ estão na faixa de quatro a cinco salārios mīnimos. (Tab. 07).

Encontramos algumas famīi ias sobrevivendo com salą rio inferior ao minimo; do que pude constatar elas eram manti das pelas mães, com ordenado que recebiam pelo serviço de do méstica, em um outro caso o sustento da familia estava sendo feito pelo aluno e seu sobrinho; isto porque os elementos adu tos da casa estavam desempregados.

Também aparece o inverso, encontramos alguns casos cuja renda da familia é superior a 15 salärios chegando mesmo duas delas a ultrapassar os 22 , apesar de que tal soma inclui salārios de vārios elementos da casa chegando atingir seis de les.

A situação configurada atravēs das informações nos mostra que $21,47 \%$ dessas famỉitas são constituídas por seis pes soas, $15,82 \%$ por sete e $14,68 \%$ por cinco; os dados apresentados correspondem à mēdia das famīlias em anālise; apesar de que $\underline{e}$ $x$ iste entre eles familias mais numerosas chegando a ter mais de 10 pessoas, embora apareçam em porcentagens pequenas; o mes mo ocorre com as que possuem poucos elementos na casa.

A investigação que relaciona o nūmero de pessoas da familia com a quantidade delas que trabalha deixou claro que a média dessas famīlias ē constituĩda por seis e sete elementos e a quantidade dos que participam do mercado de trabalho variou da seguinte forma (Tabela 08): 
TABELA 07

RENDA MENSAL DA FAMILIA DOS ENTREVISTADOS QUE INFORMARAM

\begin{tabular}{|c|c|c|c|c|c|c|c|}
\hline \multicolumn{2}{|r|}{ SALARIO } & $\begin{array}{l}\text { RITA } \\
\text { BICUDO }\end{array}$ & $\begin{array}{c}\text { ELZA } \\
\text { SARAIVA }\end{array}$ & $\begin{array}{l}\text { GUILHERME } \\
\text { DE ALMEIDA }\end{array}$ & $\begin{array}{l}\text { ALFREDO } \\
\text { GOMES }\end{array}$ & $\begin{array}{l}\text { TOTAL } \\
\text { GERAL }\end{array}$ & $\%$ \\
\hline $1 / 2$ & a 1 & 01 & - & 02 & 01 & 04 & 2,26 \\
\hline 1 & a 2 & 02 & 03 & 01 & 03 & 09 & 5,11 \\
\hline 2 & a 3 & 02 & 03 & 02 & 04 & 11 & 6,27 \\
\hline 3 & a 4 & 10 & 09 & 04 & 03 & 26 & 14,68 \\
\hline 4 & a 5 & 08 & 07 & 03 & 04 & 22 & 12,42 \\
\hline 5 & $\mathrm{a}$ & 06 & 03 & 04 & 03 & 16 & 9,03 \\
\hline 6 & a 7 & 10 & 11 & 02 & 02 & 25 & 14,18 \\
\hline 7 & a 8 & 04 & 07 & 03 & 01 & 15 & 8,47 \\
\hline 8 & a 9 & 01 & 05 & 02 & 01 & 09 & 5,08 \\
\hline 9 & a 10 & 04 & 01 & 03 & 01 & 09 & 5,08 \\
\hline 10 & a 11 & - & 03 & 01 & - & 04 & 2,25 \\
\hline 11 & a 12 & - & 05 & 01 & 01 & 07 & 3,95 \\
\hline 12 & a 13 & 01 & - & - & 01 & 02 & 1,12 \\
\hline 13 & a 14 & 01 & 01 & - & - & 02 & 1,12 \\
\hline 14 & a 15 & 01 & - & 01 & - & 02 & 1,12 \\
\hline 15 & a 16 & - & - & - & 03 & 03 & 1,69 \\
\hline 16 & a 17 & - & 01 & - & - & 01 & 0,56 \\
\hline 17 & a 18 & - & 02 & - & - & 02 & 1,12 \\
\hline 18 & a 19 & 01 & 01 & 02 & - & 04 & 2,25 \\
\hline 19 & a 20 & - & - & - & - & - & - \\
\hline 20 & a 21 & - & - & 01 & - & 01 & 0,56 \\
\hline 21 & a 22 & - & - & - & 01 & 01 & 0,56 \\
\hline 22 & acima & - & 01 & - & 01 & 02 & 1,12 \\
\hline TOTA & & 52 & 63 & 32 & 30 & 177 & 100 \\
\hline
\end{tabular}

Salārio mỉnino na época: Cr\$333.000,00

Fonte: Questionārios aplicados - Outubro/1985 
.87 .

TABELA 08

RELAÇAO ENTRE 0 Nọ DE PESSOAS QUE TRABALHAM, Nọ DE PESSOAS DA FAMTLIA E TOTAL DE FAMILIAS

\begin{tabular}{|c|c|c|c|c|c|c|c|c|c|}
\hline $\begin{array}{l}\text { NO DE PESSOAS } \\
\text { DA } \\
\text { FAMILIA }\end{array}$ & \multicolumn{8}{|c|}{$\begin{array}{c}\text { NUMERO DE PESSOAS QUE TRABALHAM } \\
\text { DAS FAMILIAS DOS ENTREVISTADOS } \\
\text { E NUMERO DE FAMILIAS }\end{array}$} & $\begin{array}{c}\text { TOTAL } \\
\text { DE } \\
\text { FAMILIAS }\end{array}$ \\
\hline FAMILIA & 1 & 2 & 3 & 4 & 5 & 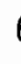 & 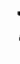 & 8 & \\
\hline 2 & 1 & & & & & & & & 01 \\
\hline 3 & 1 & 5 & 5 & & & & & & 11 \\
\hline 4 & 4 & 6 & 7 & 2 & & & & & 19 \\
\hline 5 & 1 & 7 & 13 & 9 & & & & & 30 \\
\hline 6 & 4 & 6 & 19 & 13 & 6 & & & & 48 \\
\hline 7 & 0 & 7 & 11 & 1 & 4 & & & & 37 \\
\hline 8 & - & 2 & 7 & 13 & 3 & & & & 27 \\
\hline 9 & - & 1 & 6 & 9 & 10 & & & 1 & 29 \\
\hline 10 & - & 2 & 3 & 5 & 0 & & & 0 & 16 \\
\hline 11 & 1 & 1 & 0 & 1 & 1 & & & 0 & 05 \\
\hline 12 & 0 & 0 & 0 & 0 & 0 & & & 0 & 02 \\
\hline 13 & - & - & - & - & - & & & - & - \\
\hline 14 & - & 1 & - & - & - & & & - & 01 \\
\hline TOTAL & & & & & & & & & 226 \\
\hline
\end{tabular}

Fonte: Questionārios aplicados 
As familias mais numerosas variaram de 8 a 14 elemen tos na casa e as pessoas que trabalham oscilou de 1 até 8; quan to aos que participam da força de trabalho corresponde aos pais inicialmente, os filhos vão fazendo parte dela à medida que a presentam o mīnimo de condições para fazê-lo; com as famīlias menores o fenōmeno è o mesmo.

Ficou constatado que a renda per capita naquele gru po social o maior número deles vive com menos de um salário mí nimo e corresponde a $24,86 \%$, encontramos $7,35 \%$ vivendo com me nos de meio salārio; a situação inversa que apareceu atingiu trēs salārios e meio correspondendo a $2,84 \%$ dessa população ; com renda per capita inferior a quatro salärios naquele grupo existem só dois elementos.

o grupo social que habita o Jardim Peri hoje è bem grande, originou-se de inúmeras cidades brasileiras e é fruto da migração interna que se intensificou a partir dos anos sessenta agora ampliada com oselementos que nasceram na cidade de São Paulo e que muito tem contribuido para o seu crescimento e conômico, aumentando o número de elementos que aqui vendem sua força de trabalho na indūstria, no comércio e mesmo em ativida des domésticas; embora a custas de muito sacrificio e exploração porque eles constituem um dos inúmeros loteamentos da peri feria da cidade única opção de moradia para classe de baixa renda face à segregação sōcio-espacial. 


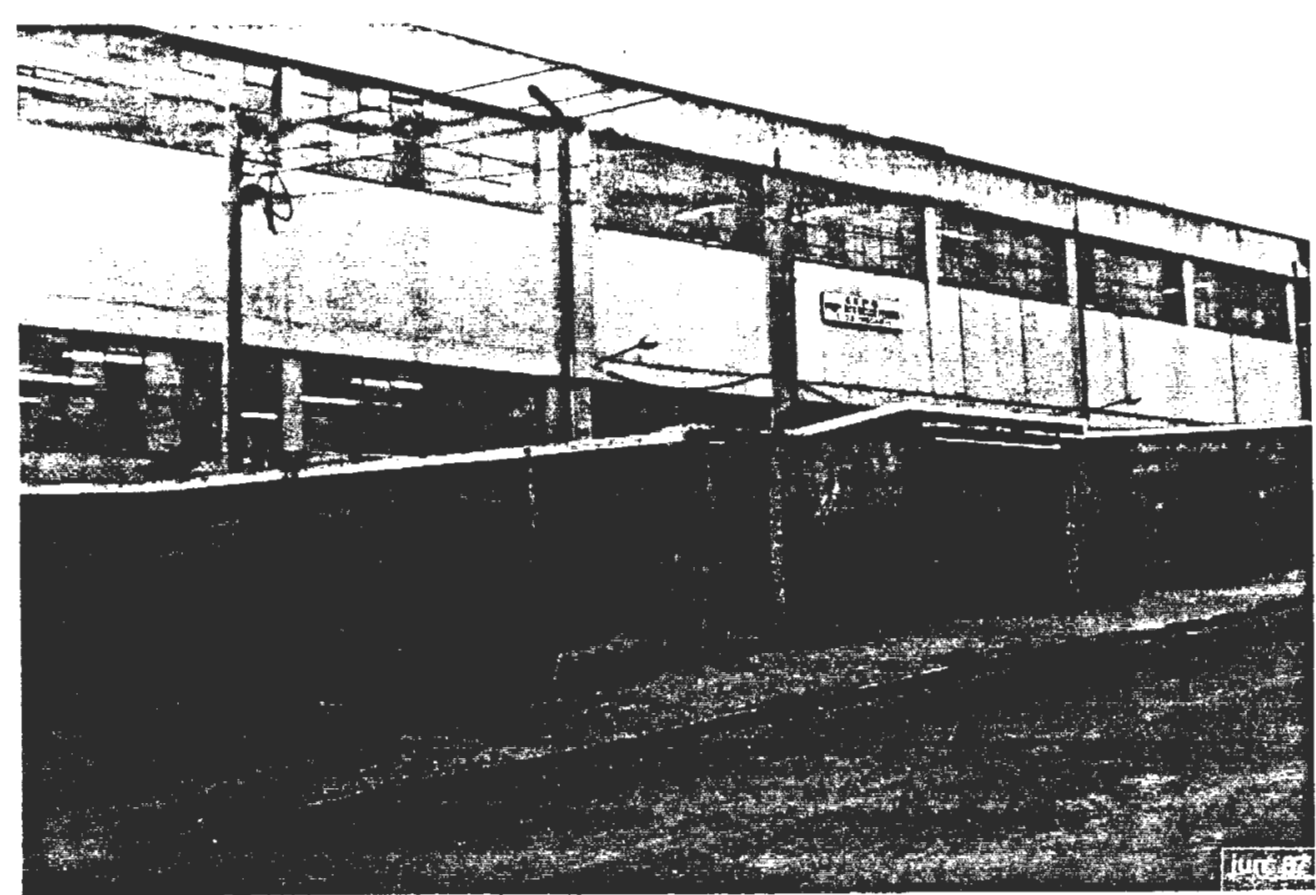

FOTO 01 - EEPG Profa. Rita Bicudo Pereira

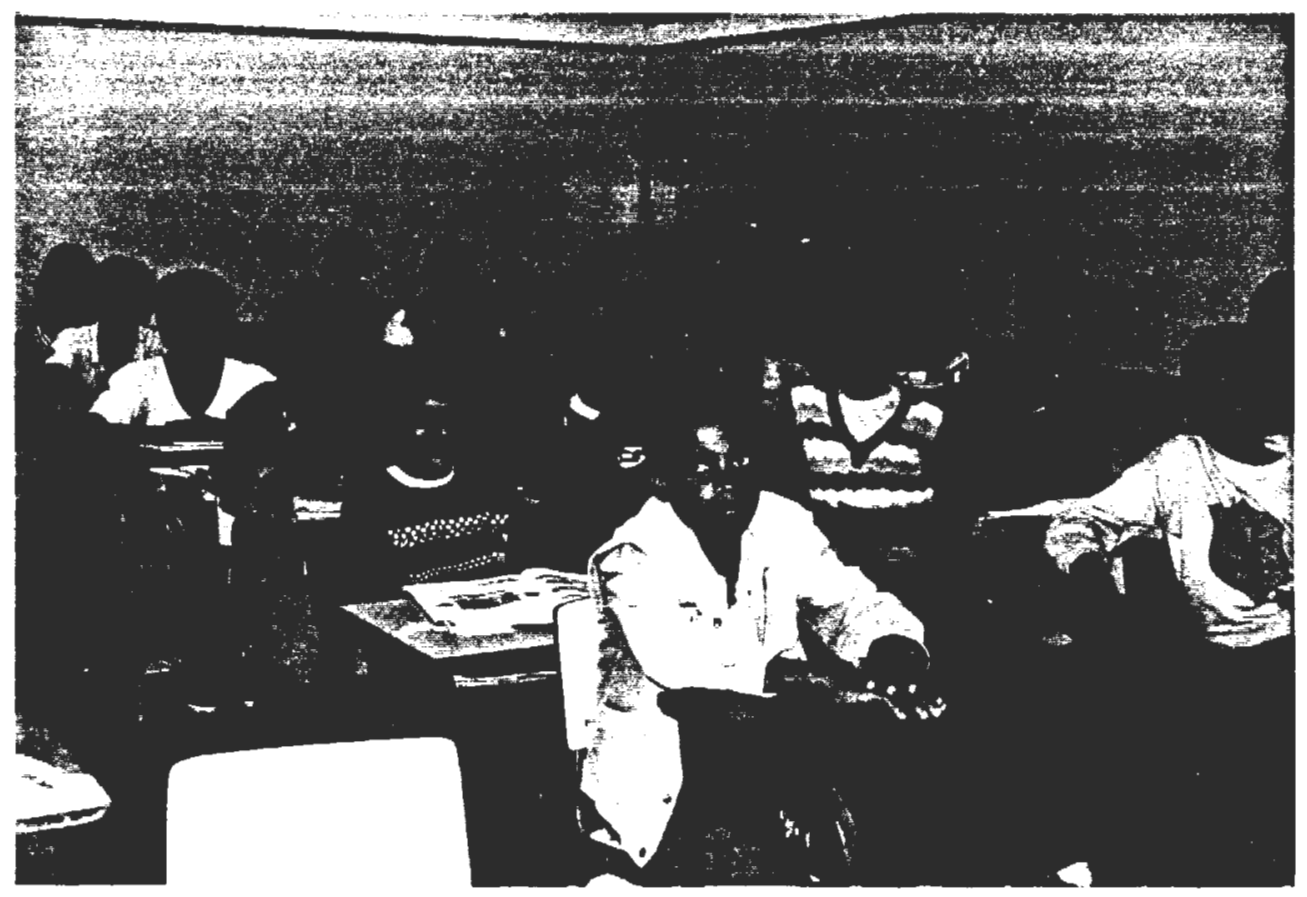

F0T0 02 - EEPG Profa. Rita Bicudo Pereira

Alunos do curso noturno 


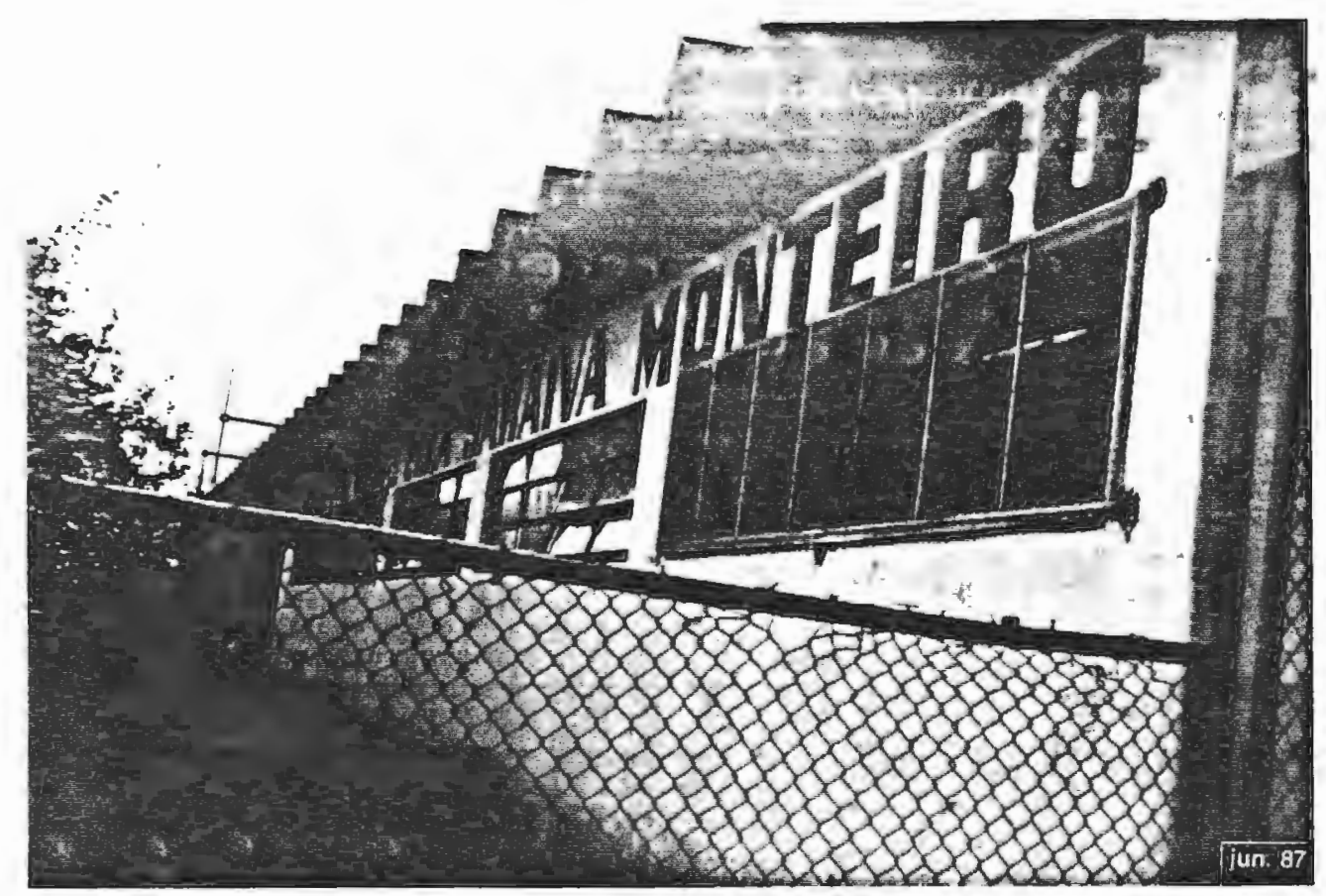

F0T0 03 - EEPG Profa. Elza Saraiva Monteiro

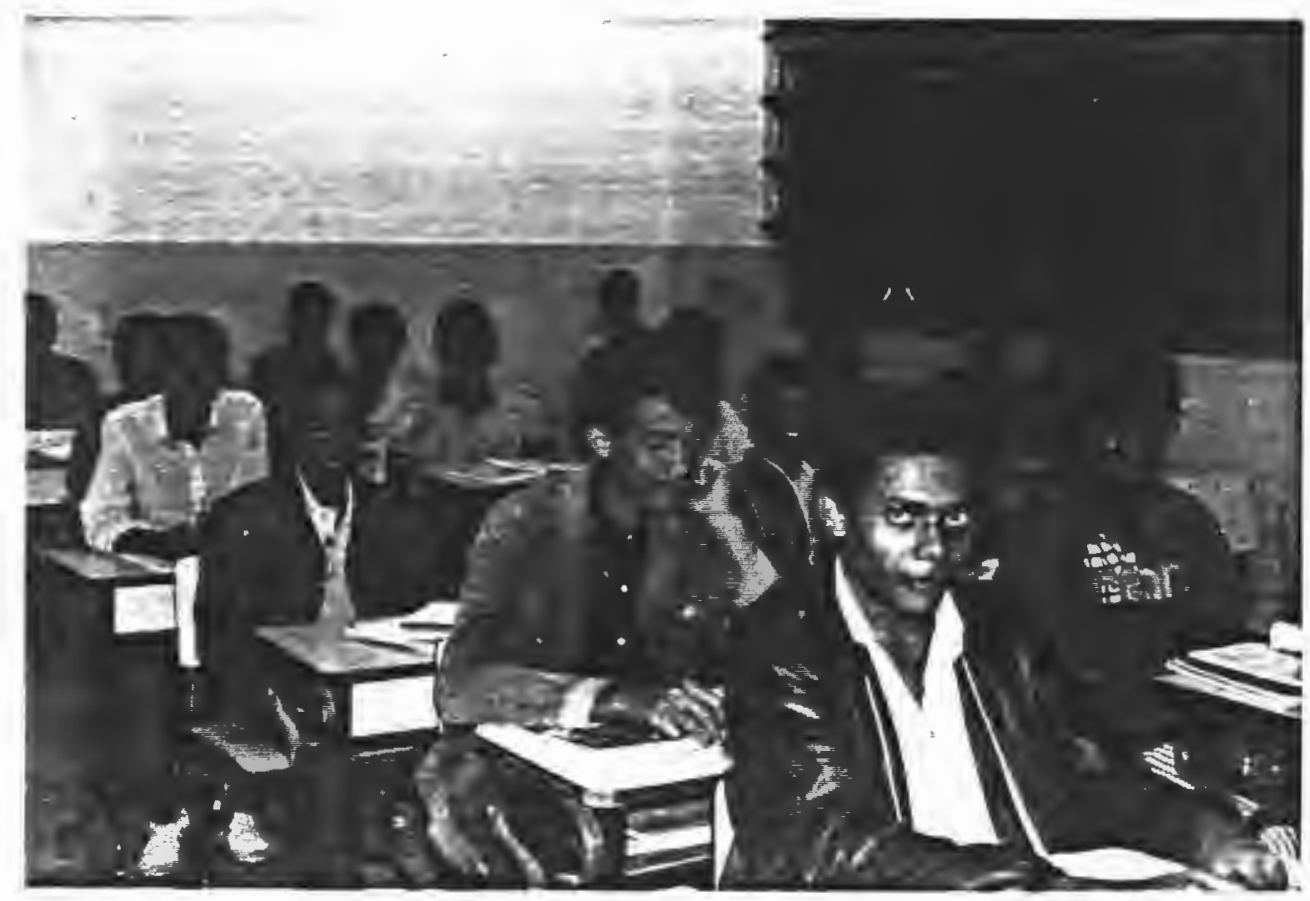

FOTO 04 - EEPG Profa. Elza Saraiva Monteiro Alunos do curso noturno 
.91.

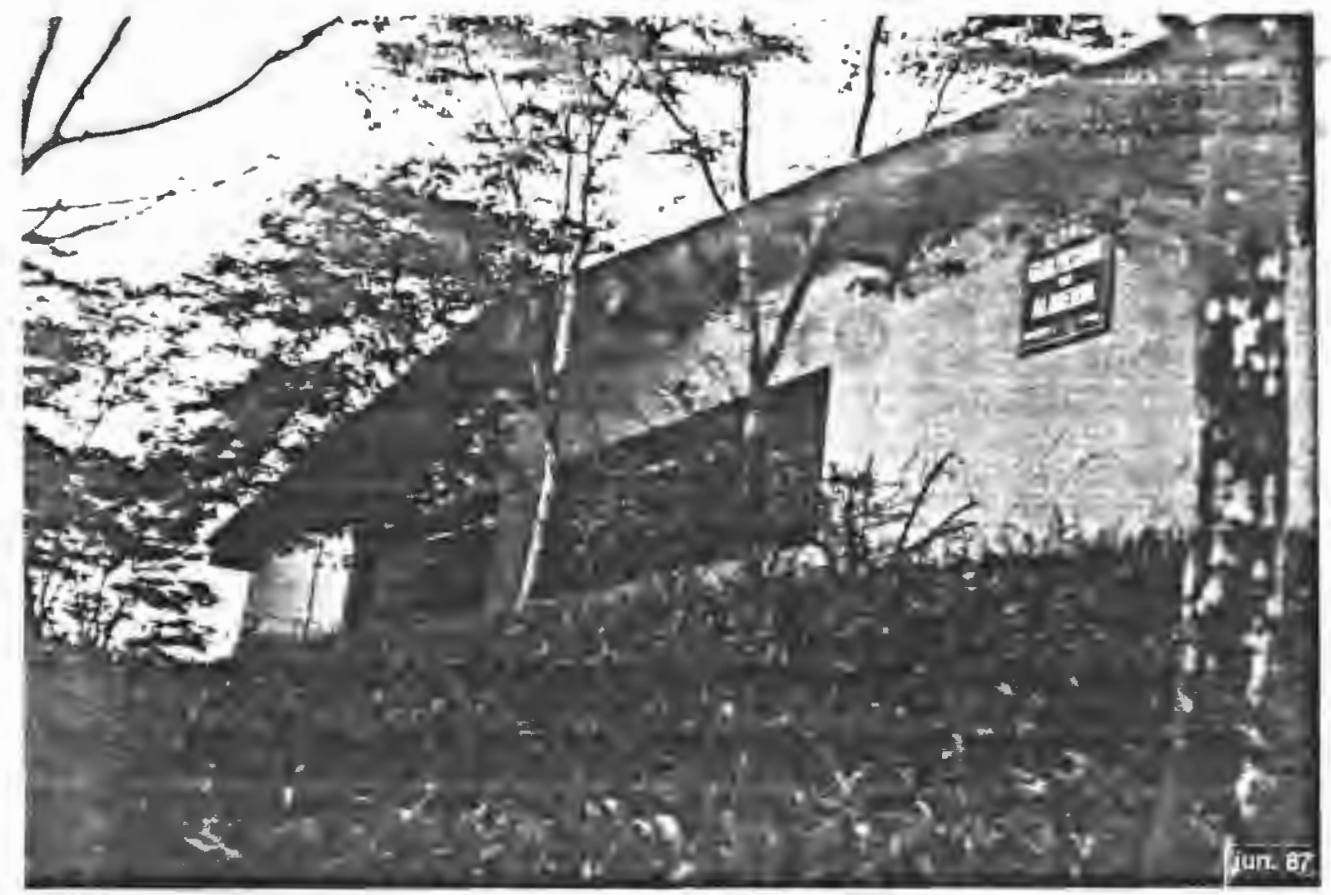

FOTO 05 - EEPG Guilherme de Almeida

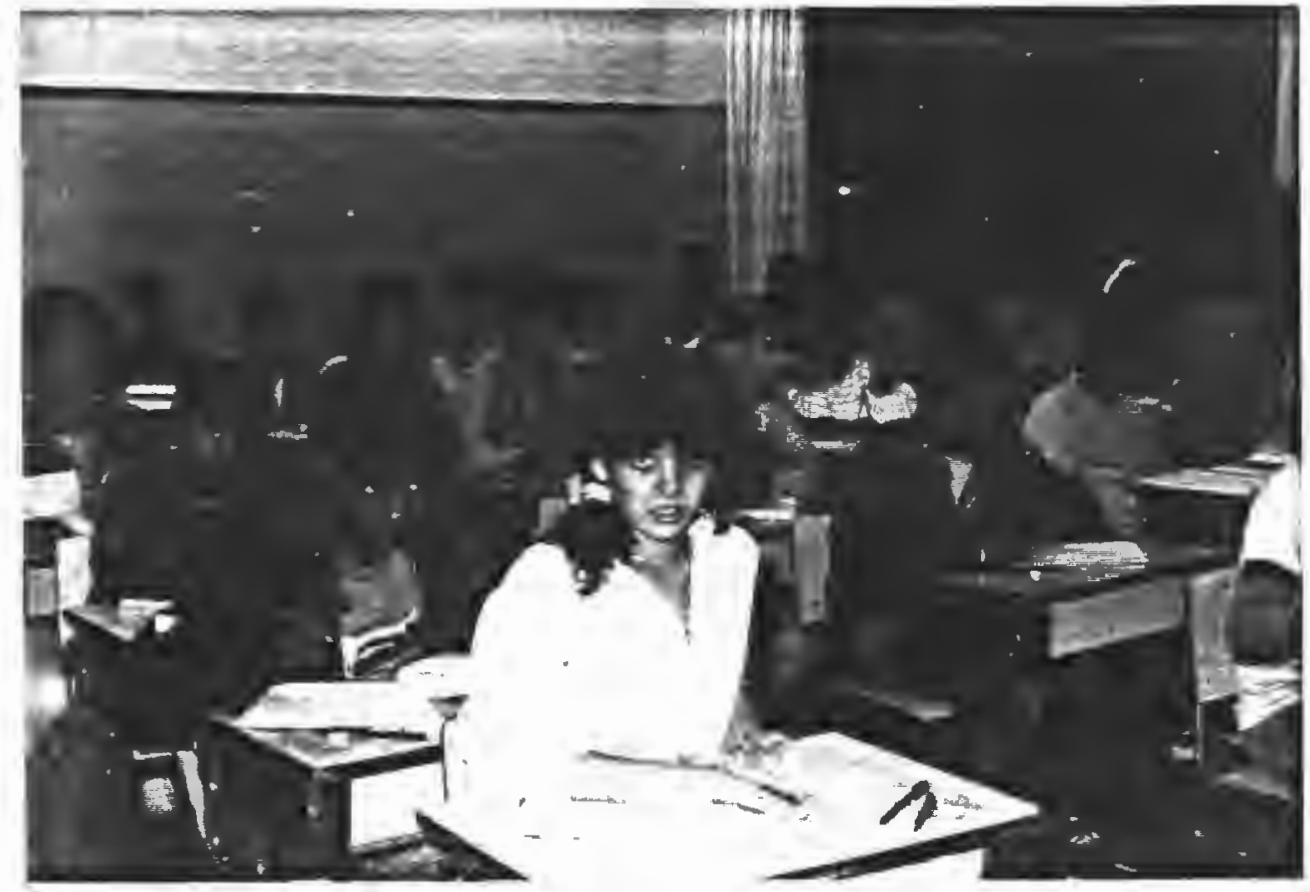

FOTO 06 - EEPG Guilherme de Almejda

Alunos do curso noturno 


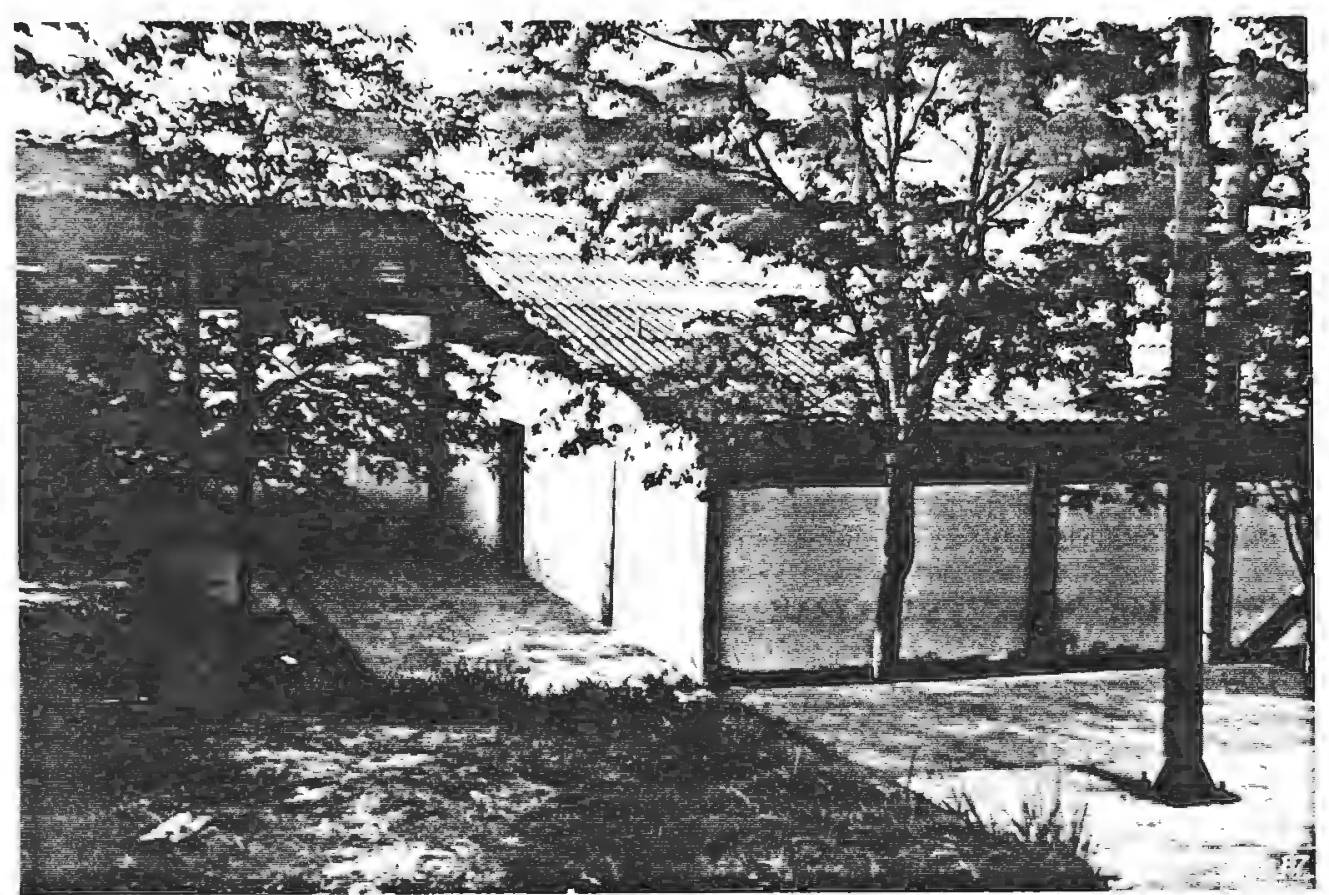

F0T0 07 - EEPG Prof. Alfredo Gomes

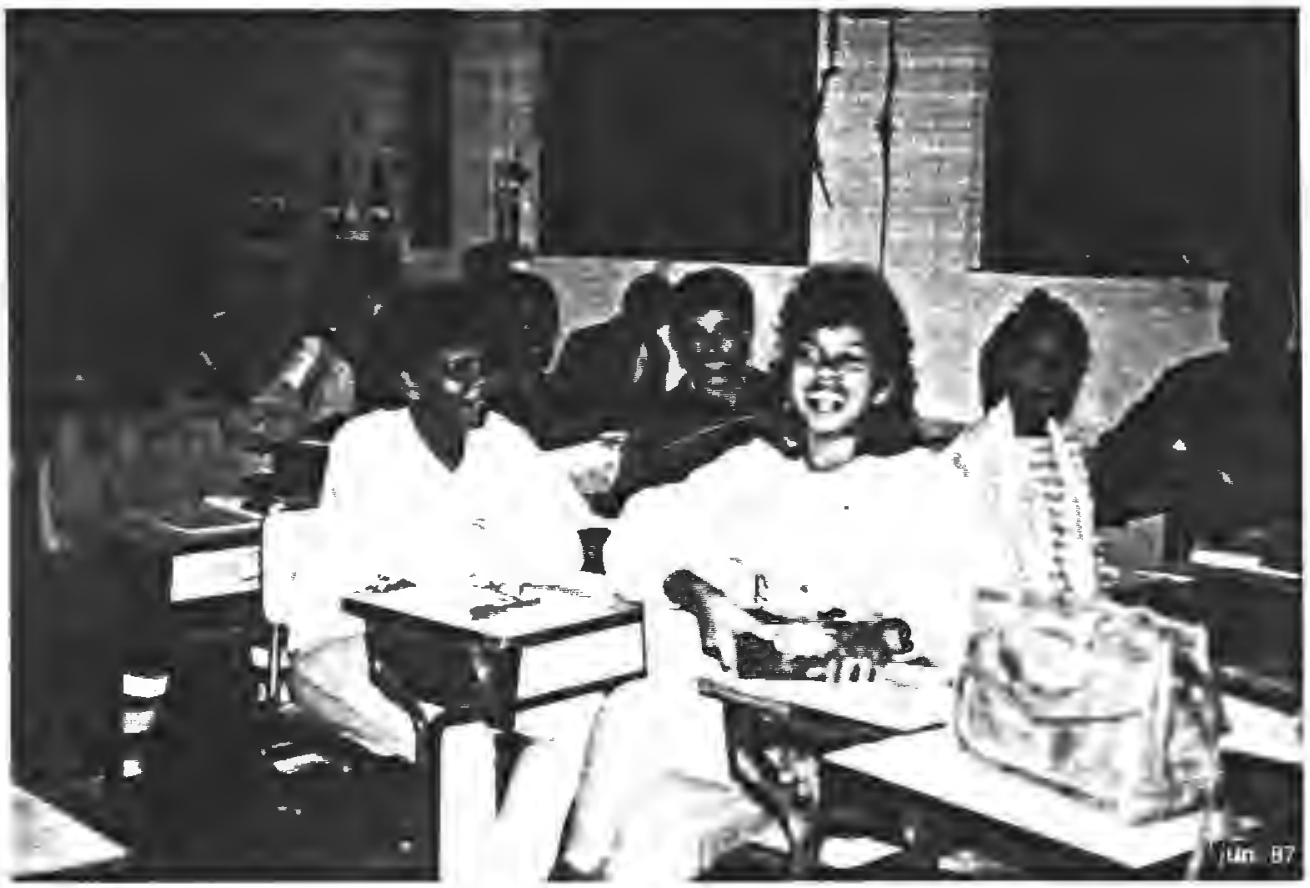

F0T0 08 - EEPG Prof. Alfredo Gomes

Alunos do curso noturno 
CAPITULO III

o trabalho e a escola 


\subsection{O trabalho e a legislação}

Quando pretendemos analisar um fato temos algumas no ções sobre a realidade, objeto de nosso estudo, que interpreta mos com base em certos conceitos que nos levam a conhecê-la me Ihor.

Uma das nossas propostas é analisar o trabalho do me nor e o seu aproveitamento escolar; para que consigamos atingir o fim proposto é importante deixar claro o que é trabalho e as suas implicações junto ao rendimento do aluno.

No campo da Filosofia:

"O trabalho $\bar{e}$, em geral, definido como uma atividade específica da espécie humana, de onde advēm a noção de seu carāter humanizador na relação que se estabe lece entre o homem e a natureza. Parte-se do pressu posto de que, no intercâmbio homem-natureza, esta se distingue do animal ao produzir seus meios de $\underline{e}$ xistência". (1)

Do ponto de vista histōrico-social encontramos em Marx uma definição bastante precisa; ele:

"... situa a relação homem-natureza no interior de um determinado modo de produção, estabelecendo en tre o trabalho e este uma estreita dependência. De um lado, o trabalho constitui e mantém o modo de produção; por outro lado, o modo de produção deter-

(1) Mora, J.F. Dicionārio de Filosofia. B. Aires, Editorial Sudamérica, 1971. 
mina as formas vālidas de trabalho. Essa formulaçäo possibilita pensar a produçāo como um processo his tōrico, consequente $\bar{a}$ atividade de trabalho como $\underline{u}$ ma categoria histórica". (1966:144)

Em uma sociedade capitalista o homem que não possui os meios de produção tem necessidade de vender sua força de trabalho, transformando a matéria-prima fornecida pela natureza em mercadoria que será comercializada no mercado em troca de dinheiro que vai garantir ao trabalhador poder adquirir ou tras mercadorias necessārias para sua sobrevivência. o trabalho possui duplo carāter, isto é, produtor de valor de uso e de va lor de troca.

\section{O trabalho infantil $\underline{e}$ a legislação brasileira}

0 trabalho infantil sempre existiu no desenvolvimento econōmico da humanidade. A nīvel mundial segundo cālculos es tatỉsticos dos Estados Unidos, em 1976 havia 56 milhões de crian ças empregadas no mundo (O.I.T., 1979 a). Outros cálculos suge rem que o nūmero é muito superior (por exemplo, 0.I.T., 1979 b). (1981:143)

A histōria contemporānea nos mostra que crianças de todas as idades sempre trabalharam em manufaturas e outros tra balhos, nem sempre em condições de higiene e saūde saudável, a lém de não ganharem porque as suas minguadas remunerações eram pagas a seus pais. Hoje não estamos muito distantes desta si tuação, grande parte das crianças trabalham, umas são remunera das outras não, porque suas tarefas se relacionam com o lar; não é possivel avaliar o seu trabalho, interpretar seu valor 
econômico e social. 0 que tem prevalecido do ponto de vista so cial è que ele è um mal que deve ser eliminado.

Num pais grande como o Brasil, onde se repetem as condições de povos diferentes e que encontramos no mesmo terri tório centros sofisticados e alta tecnologia contrastando com a misēria de grandes populações, é preciso planejar a educação e o trabalho dos menores como investimento com retorno, embora a longo prazo.

Foi fixado pela Constituição de 1934 para a sociedade brasileira em 14 anos o limite para o ingresso na força de trabalho. A CLT de 1943 acrescenta a proibição de contratação dos serviços de menores em regiões insalubres e perigosas.

A Constituição de 1946 ampliou as vantagens aos meno res proibindo diferenças salariais para um mesmo trabalho, por motivo de idade e manteve a idade minima em 14 anos.

A Constituição de 1967 baixou o limite de trabalho do menor para 12 anos aumentando a exploração infantil, realidade que fez surgir protestos na época; foi instituīdo tambēm o salário do menor que contribuiu para o rebaixamento dos ven cimentos.

Ela considera menor todo trabalhador de 12 a 18 anos e esclarece que o trabalho dos menores de 12 a 14 anos não po de impedir sua frequência à escola com finalidade de assegurar sua formação em nỉvel primārio. Posteriormente, a escolarização obrigatōria foi estendida para 8 anos ( 7 a 14 anos) e a lei do limite minimo para o ingresso ao trabalho não foi modificada. Como a escolaridade obrigatōria foi estendida até 14 anos, fi cou sendo esta a idade considerada adequada para o ingresso do 
menor na força de trabalho, em nossa sociedade.

Existe uma distorção na legislação brasileira de 1967 , quando determina que o ensino deva ser gratuito e obrigatório a toda criança brasileira de 7 a 14 anos e autoriza o inicio no trabalho aos 12, apesar de ser comum o ingresso no trabalho an terior a essa idade.

A Constituição de 1988, no artigo 7ọ, capỉtulo XXXIII, proibe o trabalho noturno perigoso ou insalubre aos menores de 18 anos e de qualquer trabalho a menores de 14 an'os, salvo na condição de aprendiz.

A nova Constituição dā direitos ao menor que pode $\underline{f} \underline{i}$ car a critērio do empregador, em função da ressalva, na condi ção de aprendiz. Ela constitui um meio atravēs do qual o empre gador pode forjar uma aprendizagem que não existe e continuar explorando o menor trabalhador.

0 artigo 227 § 30 , dá garantia de acesso do trabalhá dor adolescente à escola; embora seja de nosso conhecimento que - curso noturno transmite a seus alunos uma carga reduzida de conteūdo, em virtude deles não terem condição de assimilar mui ta coisa depois da jornada de trabalho. Tal fato vai continuar ocasionando a discriminação social no interior da própria esco la, além de não existirem vagas para todos os adolescentes.

A legislação vigente assegura como dever do Estado com a educação mediante a garantia de progressiva extensão da obrigatoriedade e gratuidade do ensino médio (artigo 208).

$$
\text { Vê-se, portanto, que existe uma discrepância na le }
$$
gislação brasileira em virtude de existirem loteamentos da pe 
riferia da cidade de São Paulo, uma das mais importantes do paīs, que não possuem ensino médio; o Jardim Peri é um exemplo deles.

O Estado entendido aqui como sendo um conjunto iden tificāvel de instituições que organiza e atua em todos os a pectos da vida social, assume papel importante no direcionamen to da força de trabalho jovem, razão pela qual pretendemos nes ta pesquisa identificar sua atuação quanto à educação.

\subsection{O universo da pesquisa e propostas de trabalho}

A partir de uma redefinição de conceitos se adotam novas práticas metodológicas. o conhecimento popular deixa de ser sinōnimo de falta do saber a partir de sua valorização. Ele passa a ser referência de grupos que sofrem igual situação social e econōmica.

Segundo Amalia Inēs Geraiges de Lemos (1987:1):

"... dentro da concepção educacional, se procura $\underline{u}$ ma relação de educação conscientizadora das clas ses populares. A realidade começa a ser analisada como um processo no qual as classes sociais pos suem papéis determinantes".

Na sequència de seu trabalho ela coloca a sociologia integrando na prātica da realidade a partir de opção de traba 1 ho junto aos grupos dominados e pobres a participar dos movimentos populares.

Existem tēcnicas e mētodos que: 
"... permitem conhecer, questionare agir scbre o ob jeto ou realidade estudada e possibilitam a participação dos setores populares na tarefa de desco brir sua prōpria realidade". (Gajardo, M. 1986:16)

E prātica de Paulo Freire a forma alternativa de pes quisa e ação educativa, com finalidade de maior participação so cial.

Com esse propósito colocaremos nossa experiēncia pes soal pesquisando a realidade dos estudantes do Jardim Peri.

Nosso contato diāria com a ārea de investigação nos levou a ter vivēncia mais próxima dos problemas que pretendiamos analisar. Torna-se difïcil quando se tem maior ligação com - objeto de estudo, não tomar conhecimento das suas necessidades, da sua vida, das suas inquietudes.

Atravēs das respostas dos questionārios aplicadosche gou a nosso conhecimento que existiam entre eles vārios alunos que trabalhavam e não possuiam registro em carteira, além de terem uma jornada de trabal ho com nümero de horas superior ao permitido.

Foi dado esclarecimento dos direitos do cidadão e do menor, atravēs da CLT a fim de que eles se dirigissem à Sociedade Amigos do Bairro e formalizassem suas reivindicações ex $\mathbf{i}$ gindo dessa maneira o cumprimento legal dos seus direitos.

Em situação diversa foi conseguida a reforma e amplia ção do nosso prédio escolar que na ocasião estava em péssimas condições; nessa época funcionavam duas classes por periodo em um barracão de madeira. 
A direção da escola com o apoio da Sociedade Amigos do Bairro formalizou o pedido frente às autoridádes competentes e foram atendidos.

Como nos mostra Geraiges de Lemos (1987:5):

"Quando se compartilha o cotidiano da realidade so cial, quando o pesquisador convive com pessoas reais, com suas culturas e seus grupos sociais a pesquisa participante estā sendo realizada. A partir deste momento o pesquisador participa da história do ob jeto da pesquisa. Não mais se pode dividir, sepa rar, a teoria da prätica".

Nosso contato com alunos e pais nos possibilita com preender suas histórias de vida e atravēs delas pudemos chegar a novas formas de explicar a realidade.

Essa incompatibilidade è a responsāvel por novas for mas especiais que convivem e ao mesmo tempo se chocam.

A iniciação nessa vivēncia, o conceito de espaço que aprendemos na graduação e que assumimos, aqui começa a ter con teūdo e essência:

"... o espaço se define como um conjunto de formas representativas de relações sociais do passado e do presente e por uma estrutura representada por relações sociais que estão acontecendo diante dos nossos olhos e que se manifestam através de proces sos e funções. O espaço é então, um verdadeiro cam po de forças cuja aceleração $\bar{e}$ desigual". ISantos, M. $1978: 1221$

A forma pela qual os habitantes do Jardim Peri tēm se organizado no espaço urbano tem como resultado várias mane ras de utilização daquele solo, com caracterīsticas específicas 
dos seus ocupantes.

Esta prática nos leva a refletir e também a repensar o comportamento humano.

"A relação de participação da prātica científica no trabalho politico das classes populares desafia o pesquisador a ver e compreender tais classes, seus sujeitos e seus mundos, tanto através de suas pes soas nominadas, quanto a partir de um trabalho so cial e politico de classe que, constituindo a ra zão da prātica, constitui igualmente a razão da pesquisa". (Brandão, R.D., 1985:13)

Dessa maneira vemos integrada a pesquisa participante na Geo grafia humana.

\subsection{Anālise dos dadcs obtidos no questionārio}

Para a anālise desta realidade foram aplicados 332 questionārios dos quais 106 estavam incompletos e 226 foram a proveitados, isto foi feito em quatro escolas da zona Norte da cidade de São Paulo, como jā foi mencionado. Duas delas se lo calizam no Jardim Peri, a EEPG Profa. Rita Bicudo Pereira e a EEPG Profa: Elza Saraiva Monteiro, as outras ficam em locais vizinhos; a EEPG Prof. Alfredo Gomes se localiza na Vila Bela Vista e a EEPG Guilherme de Almeida na Vila Amālia.

Na EEPG Profa. Rita Bicudo Pereira foram aplicados 97 questionários dos quais 38 estavam incompletos e foram avaliadas as opinões de 59 alunos, cujas idades variaram de 12 a 18 anos; destes 35 são do sexo masculino e 24 do sexo feminino;um é casado e aluno da oitava série. 
Quanto ao local de nascimento destes jovens, predomi nou a capital de São Paulo, com um nümero de 29 alunos; 4 são do interior; dos outros estados brasileiros prevaleceu Minas Gerais com 8, a Bahia com 7, o Ceará com 4 e respectivamente Pá ranā com 3, Pernambuco com 2, Maranhão e Paraỉba com 1 . 0 nī vel de escolaridade deles é lọ grau, cursando as sēries entre $5 \stackrel{a}{\text { e }} 8 \stackrel{\text { a }}{\text {. }}$

Destes alunos, $77,96 \%$ trabalham e $22,03 \%$ não tem ati vidade remunerada embora deste total 08 são meninas e a maio ria delas desempenha tarefas domésticas para que as mães te nham condições de ganho fora de casa; isto significa que das pessoas envolvidas nesse levantamento 5 alunos do sexo mascul $\underline{i}$ no são os que tem o dia todo para estudar e estão distribuĩdos

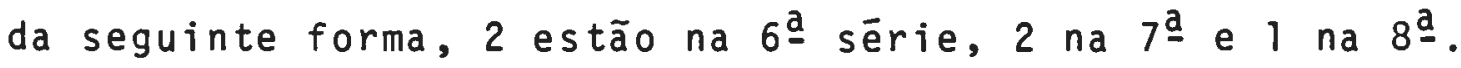

Das ocupações desempenhadas por essas pessoas vai predominar o comércio, estando incluīdas a $\bar{i}$ as atividades de vendedor, balconista, caixa, pacoteiro, ajudante geral; são 14 meninos e 04 meninas. Em seguida, vamos encontrar a indústriaartesanal com um número de 15 pessoas trabalhando nela, distrí buidos entre metalūrgicos, serralheiros, mecānicos, costureiras (indústria de confecção). No escritōrio, encontramos 07 dos quais 06 são rapazes e 01 moça; na construção civil, com ativi dade de pedreiro apareceram 04 e temos ainda 02 moças empregadas em casa de famīlia desempenhando a função de domēstica. (Fig.11)

Ao analisar a tabela demonstrativa de salário consta tei que informaram sua renda 46 alunos dos quais 30 são meninos e 16 são meninas. Quanto à remuneração recebida por eles predominava entre um e um e meio salários correspondendo a 


$$
\text { " }
$$

$\square+1111$

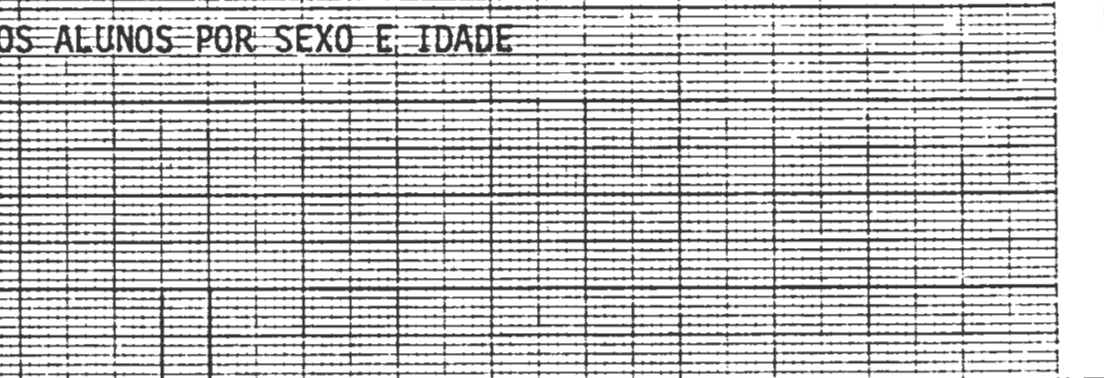


$41,33 \%$; O número daqueles que recebem menos de um salärio é a to, estando entre eles $26,08 \%$, em seguida vai aparecer $15,21 \%$ que tem ordenado igual a um salário, $13,04 \%$ dos alunos re cebem entre um e meio e dois salärios; com renda maior de dois salários mỉnimos encontramos só duas pessoas correspondendo a 4,34\%. (vide Tabela 09).

Em relação à EEPG Profa. Elza Saraiva Monteiro tam bēm localizada no Jardim Peri, embora esteja a trēs quilômetros mais distante do que a EEPG Profa. Rita Bicudo Pereira, questionamos 71 alunos cujas respostas foram consideradas boas. En tre eles 31 são rapazes com idade entre 14 e 18 anos e 40 são moças com idade de 13 a 18 anos.

A clientela desta escola é predominantemente formada por meninas, o que não ocorreu com a anterior; e tambēm vai a parecer um nūmero maior de meninas com atividades domésticas sem remuneração; encontramos o dobro delas trabalhando no co mércio; na indústria a quantidade é menor, aumentando o número de alunas que trabalham em atividades domésticas remuneradas e são quatro as que trabalham em escritório.

Os rapazes entrevistados desta escola são em menor número, dos trabalhadores predominam aqueles que possuem ativi dade no comércio, em seguida aparecem aqueles que trabalham na indústria artesanal; cinco estão no setor terciário (escritōrio), trēs no comércio ambulante e seis (correspondendo a 19,35\%) não trabalham. (vide Figura 12).

Quanto ao local de nascimento dessas pessoas, nessa escola vai predominar alunos nascidos na cidade de São Paulo, 9 nasceram no interior de São Paulo, 08 na Bahia, 07 no Paranā, 
TABELA 09

SALARIO DOS ALUNOS 10-11/85 Cr\$333.000,00

\begin{tabular}{lccccccc}
\hline \multirow{2}{*}{ FAIXA SALARIAL } & \multicolumn{2}{c}{ HOMEM } & \multicolumn{2}{c}{ MULHER } & \multicolumn{2}{c}{ TOTAL } \\
& ABS & $\%$ & ABS & $\%$ & ABS & $\%$ \\
\hline EEPG Profa. Rita B. Pereira & & & & & & \\
Menos de 1 salärio & 08 & 26,66 & 04 & 25,0 & 12 & 26,08 \\
Igual a 1 salário & 05 & 16,66 & 02 & 12,5 & 07 & 15,21 \\
Entre 1 e 1/2 salärio & 13 & 43,33 & 06 & 37,5 & 19 & 41,33 \\
Entre 1/2 e 2 salärios & 03 & 10,02 & 03 & 18,75 & 06 & 13,04 \\
$>\quad 2$ salārios & 01 & 3,33 & 01 & 6,25 & 02 & 4,34 \\
$>\quad 3$ salários & - & - & - & - & - & - \\
\hline Total & 30 & 100 & 16 & 100 & 46 & 100 \\
\hline
\end{tabular}

EEPG Profa. Elza S. Monteiro

\begin{tabular}{lllllll}
\hline Menos de 1 salärio & 02 & 8,33 & 10 & 40,0 & 12 & 25,12
\end{tabular}

$\begin{array}{lllllll}\text { Igual a } 1 \text { salärio } & 03 & 12,5 & 07 & 28,0 & 10 & 20,71\end{array}$

$\begin{array}{lllllll}\text { Entre } 1 \text { e } 1 / 2 \text { salärio } & 09 & 37,5 & 06 & 24,0 & 15 & 30,72\end{array}$

$\begin{array}{lllllll}\text { Entre } 1 / 2 \text { e } 2 \text { salärios } & 03 & 12.5 & 02 & 8.0 & 05 & 10,31\end{array}$

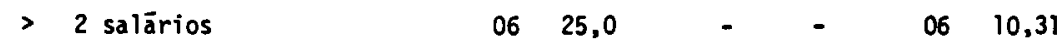

\begin{tabular}{|c|c|c|c|c|c|c|}
\hline$>\quad 3$ salärios & 01 & 4,17 & - & - & 01 & 2,83 \\
\hline Total & 24 & 100 & 25 & 100 & 48 & 100 \\
\hline
\end{tabular}

\begin{tabular}{lccccccc} 
EEPG Guilherme Guimaräes & & & & & & \\
\hline Menos de 1 salärio & 02 & 9,51 & 05 & 38,46 & 07 & 20,58 \\
Igual a 1 salärio & 04 & 19,09 & 04 & 30,78 & 08 & 23,53 \\
Entre 1 e $1 / 2$ salärio & 09 & 42,85 & 02 & 15,38 & 11 & 32,35 \\
Entre $1 / 2$ e 2 salärios & 05 & 23,80 & 01 & 7,69 & 06 & 17,65 \\
$>\quad 2$ salärios & 01 & 4,75 & 01 & 7,69 & 02 & 5,89 \\
$>\quad 3$ salärios & - & - & - & - & - & - \\
\hline Total & 21 & 100 & 13 & 100 & 34 & 100 \\
\hline
\end{tabular}

EEPG Prof. Alfredo Gomes

\begin{tabular}{lcccccc}
\hline Menos de 1 salário & - & - & 03 & 42,86 & 03 & 13,04 \\
Igual a 1 salärio & 04 & 25,0 & - & - & 04 & 17,40 \\
Entre 1 e $1 / 2$ salārio & 04 & 25,0 & 03 & 42,86 & 07 & 30,43 \\
Entre $1 / 2$ e 2 salārios & 03 & 18,75 & 01 & 14,28 & 04 & 17,40 \\
$>\quad 2$ salärios & 05 & 31,25 & - & - & 05 & 21,73 \\
$>\quad 3$ salärios & - & - & - & - & - & - \\
\hline Total & 16 & 100 & 07 & 100 & 23 & 100 \\
\hline
\end{tabular}

\begin{tabular}{lcccccc} 
Total das escolas & 12 & 13,18 & 22 & 36,07 & 34 & 22,36 \\
\hline Menos de 1 salärio & 16 & 17,58 & 13 & 21,32 & 29 & 19,07 \\
Igual a 1 salärio & 35 & 38,47 & 17 & 27,87 & 52 & 34,21 \\
Entre 1 e 1/2 salário & 14 & 15,39 & 07 & 11,47 & 21 & 13,82 \\
Entre 1/2 a 2 salärios & 13 & 14,29 & 02 & 3,27 & 15 & 9,87 \\
$>\quad 2$ salärios & 01 & 1,09 & - & - & 01 & 0,67 \\
$>\quad 3$ salärios & 91 & 100 & 61 & 100 & 152 & 100 \\
\hline Total & & & & & &
\end{tabular}

Fonte: Questionärios aplicados - Outubro/1985 


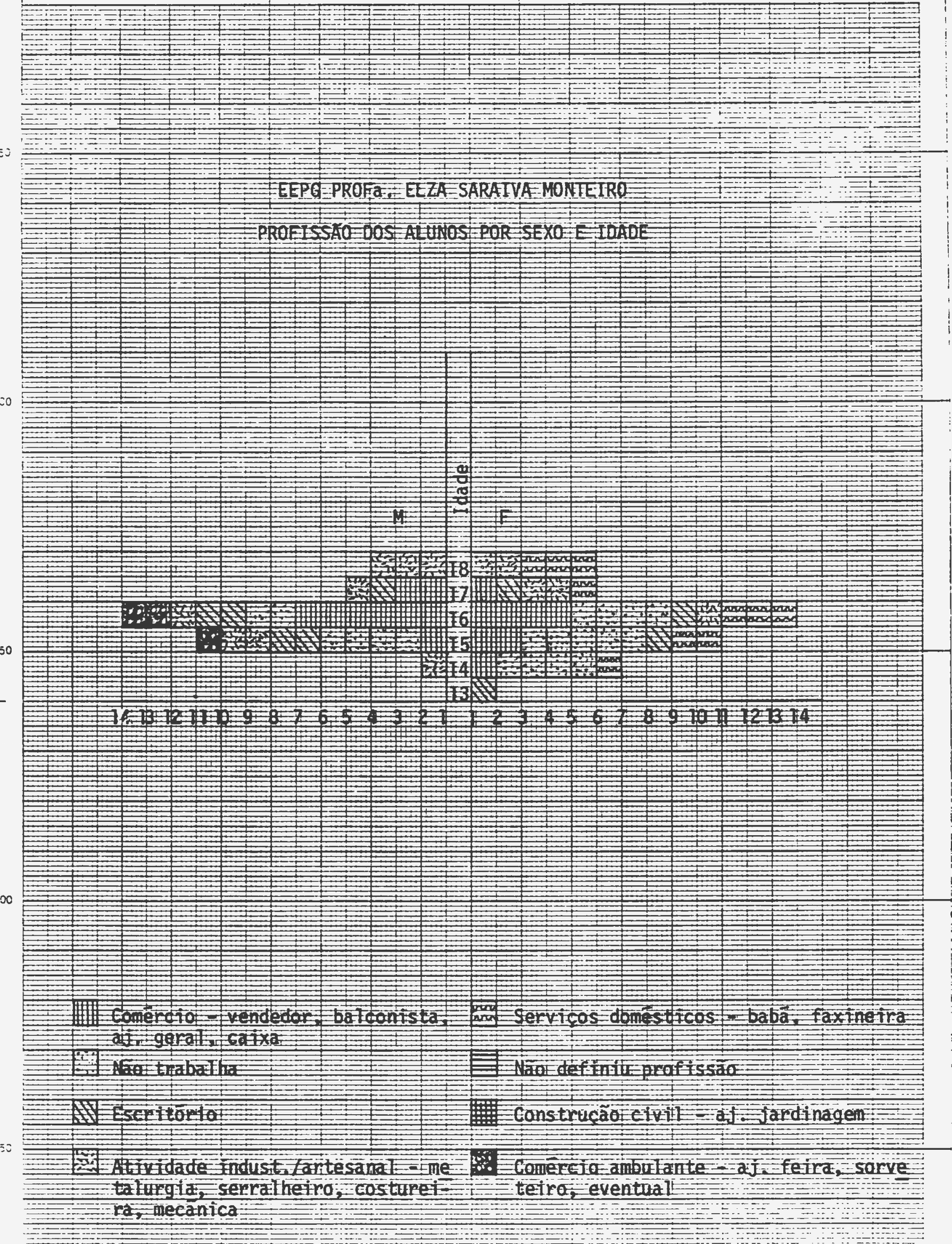


em menor proporção vão aparecer os demais estados. Este fato vai ser semelhante nas outras duas escolas que fazem parte da pes quisa: predominam alunos nascidos na cidade de São Paulo, 34 na EEPG Guilherme de Almeida, 31 na EEPG Prof. Alfredo Gomes); do interior do Estado de São Paulo temos 05 nas duas escolas, em proporção menos significativas vão aparecer Minas Gerais com 03 e 02 alunos, Bahia 05 e 01 e 02 de Pernambuco,e 1 da Paraíba. (Tab. 01)

Dos salärios recebidos pelos alunos predominam entre um e um e meio numa porcentagem de $41,33 \%$ na EEPG Profa. Rita Bicu do Pereira, $32,35 \%$ na EEPG Guilherme de Almeida, 30,72\% na EEPG Profa. Elza Saraiva Monteiro e 30,43\% na EEPG Prof. Alfredo Go mes. Aparece um número bastante significativo daqueles que rece bem menos de um salārio, estando equilibrada a porcentagem en tre os elementos na EEPG Profa. Rita Bicudo Pereira $(26,08 \%)$ e a EEPG Profa. Elza Saraiva Monteiro (25,12\%) para (20,58\%) na EEPG Guilherme de Almeida e $(13,04 \%)$ na EEPG Prof. Alfredo Go mes; acima de trēs salārios apareceu um aluno da EEPG Profa. El za Saraiva Monteiro. (Tabela 09).

E importante observar que os maiores salários são a tribuidos para as pessoas do sexo masculino. Ao me referir aos tipos de ocupações desempenhadas por eles, entre as escolas, $\underline{\text { e }}$ las se assemelham embora na atividade de comércio e indūstria a tesanal vamos encontrar um maior número na EEPG Profa. Rita Bị. cudo Pereira seguida pela EEPG Profa. Elza Saraiva Monteiro, EEPG Guilherme de Almeida, EEPG Prof. Alfredo Gomes. Desempenhan do serviços de escritōrio a situação se inverte, aparecendo prị meiro a EEPG Guilherme de Almeida, seguida pelaEEPG Profa.Elza Sa raiva Monteiro, EEPG Prof. Alfredo Gomes e EEPG Profa. Rita Bi 
cudo Pereira; trabalhando na construção civil aparece 4 alunos da EEPG Profa. Rita Bicudo Pereira e 1 da EEPG Prof. Alfredo Go mes, os que se ocupam do comércio ambulante são poucos. Aparece um nūmero significativo daqueles que não trabalham embora os dados indique mais meninas sem função, o que vem constatar que elas desempenham serviços domésticos para que suas mães possam sair de casa com o intuito de desempenhar outra função remunera da; isto ocorre de forma mais acentuada na EEPG Prof. Alfredo Go mes. (Figura 13 e 14 ).

Do meu contato com os alunos quando apliquei o questio närio constatei que o nível de organização familiar, educacional, econōmico da clientela da EEPG Prof. Alfredo Gomes ē a menos fá vorecida das escolas envolvidas na pesquisa. Lá, para conseguir dez formulārios preenchidos foi necessārio juntar duas classes por falta de frequência dos alunos ou mesmo desistēncia; convēm lembrar que eu estive fazendo a entrevista nos dias 6,7 e 13 de novembro de 1985. O comportamento deles não foi satisfatōrio; apesar de eu ter explicado a finalidade da pesquisa vārios se negaram a responder como tambēm encontrei respostas agressivas, termos de baixo nỉvel e no item que pedia informação de salário e renda familiar não deram; a compreensão das respostas foi di fícil pela dificuldade que eles têm de escrever.

Nesse dia cheguei na escola no início do periodoe con segui alunos só a partir da 2 a aula, a maioria deles trabalha longe e chega tarde; mesmo assim o tempo que dispensaram para responder às questões foi fracionado, pois a preocupação deles era saber o horārio que iriam embora e quais os professores que tinham faltado, algumas classes foram dispensadas depois da ter 
.108

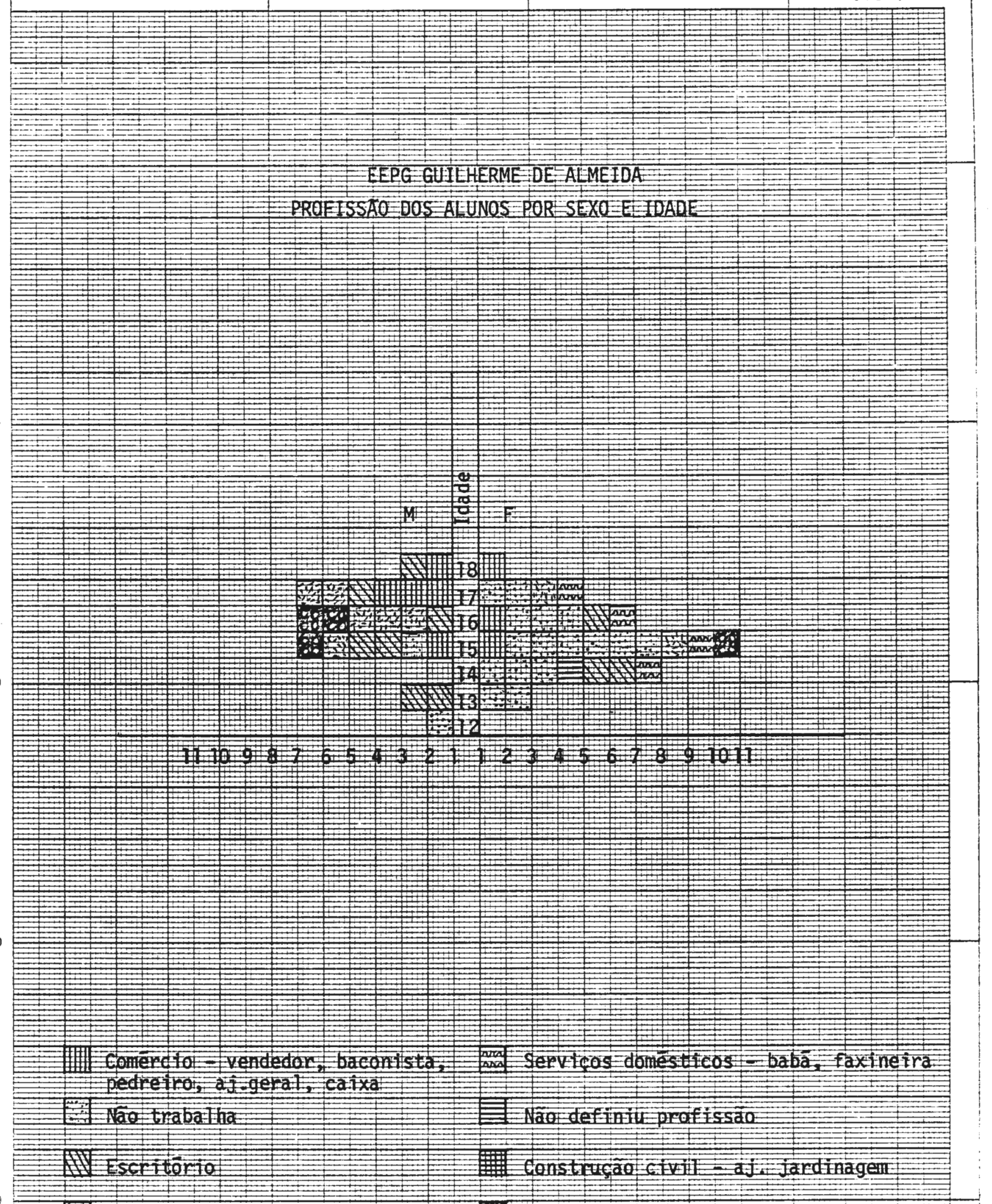

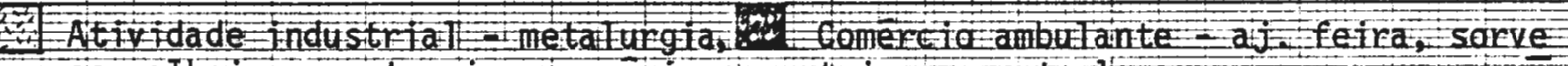
Serratheiro, Costureira, meeantica tetro, eventual: 


\section{EEPG PROF ALFREOO GOMES}

PROEISSAOAOOS ALLUNOS BOR SEXO $E$ IDADE 
ceira aula e a minha pesquisa foi entregue sem terminar; a con clusão da mesma foi efetuada em outro dia.

A aparēncia deles ē de jovens sofridos, cansados, suas roupas são bastante simples, de pouca qualidade e surradas sig nificando isto o baixo poder aquisitivo daquela clientela. En trevistando vārias funcionárias da escola elas me contaram que bem poucos alunos vão lá para estudar, o interesse estā mais voltado para brincadeira, diālogo com colegas, encontro com as meninas, talvez por ser o local da área onde eles encontram mais segurança; as ruas das imediações são perigosas, elas se encontram entre duas favelas onde marginais perigosos se refugiam .

Na EEPG Profa. Elza Saraiva Monteiro a situação é sẹ melhante, embora o nível dos alunos seja um pouco melhor encon trei a escola com maior frequēncia, os questionários que eles responderam estavam mais legiveis e completos significando me lhor nîvel, a aparēncia física e da indumentāria era um pouco superior.

Hoje os alunos da EEPG Profa. Rita Bicudo Pereira são de classe mēdia baixa trabalhadora e apresentam melhores cond ções do que as escolas anteriores, ela se localiza em uma área mais central.

Em 1972 quando cheguei no Jardim Peri para lecionar só existia a EEPG Profa. Rita Bicudo Pereira e a clientela era bem mais pobre do que a atual; aquele setor urbano cresceu mu to e ela é hoje a escola central. De forma natural a clientela de nível menor foi sendo transferida para as regiões mais distantes. 
Jā a EEPG Guilherme de Almeida è a que apresenta alü nos de melhor situação das quatro envolvidas na pesquisa; ela foi criada em 1977 num local distante de favelas, as pessoas que ela assiste são pobres embora possuam uma constituição fami liar mais organizada.

Dados fornecidos pelas escolas mostram que nos anos de 1984, 1985, 1986 ela conseguiu formar o maior nūmero de alu nos, 291, enquanto que a EEPG Profa. Rita Bicudo Pereira for mou 161, a EEPG Profa. Elza Saraiva Monteiro 130 e a EEPG Prof. Alfredo Gomes 65 .

A EEPG Guilherme de Almeida tambēm tem o maior nūme ro de classes funcionando no periodo noturno.

E importante mostrar a preocupação da geografia huma na na investigação do tipo de vida da população estudantil e de seus familiares, pessoas que habitam o Jardim Peri e āreas vizi nhas, mediante a constatação de anālise feita, esses estudantes constituem pessoas que nasceram na capital de São Paulo e hoje fazem parte da força produtiva da cidade.

E objeto da geografia a maneira pela qual o espaço do loteamento que elas moram foi produzido, embora façam parte tam bēm fenōmenos ligados à histōria econōmica e polītica. Afinal de contas, os indivĩduos que ocupam o espaço geogräfico são seres com vontade, aspirações, sentimentos e desejos.

Como nos mostra Carlos Walter:

"Os homens socialmente produzem a sua Geografia para se reproduzirem enquanto seres humanos num contexto de relações sociais determinadas". IGonçalves, Car los walter, 1985:71 
Atravēs do histōrico das escolas, constatei que a ex pansão daquele setor urbano ocorreu no perĩodo que a Metrópole de São Paulo era a mediadora na integração da economia do país e o mercado internacional. O espaço urbano concentra as indús trias e os centros de decisões das multinacionais; motivo que $\underline{0}$ casionou o aparecimento de grande variedade de empregos.

Os movimentos migratórios se multiplicam voltados com interesse no mercado de trabalho que a cidade oferecia. E vert $\underline{i}$ ginoso o crescimento demogrāfico da região metropolitana, ocasionando o surgimento de bairros cada vez mais distantes, única solução para famỉlias de baixa renda; foi nesse perīodo que o Jardim Peri iniciou sua expansão que não terminou atē hoje.

No princỉpio as áreas verdes eram substituỉdas por ha bitações modestas que aumentaram de forma gradativa. Hoje as ca sas cobrem os morros intermediadas por ruas estreitas, as cen trais asfaltadas com calçada pequena em alguns trechos, nos de mais elas não existem e os transeuntes têm que trafegar na rua; as demais são de terra. Como jā foi colocado o aumento populacio nal ocasionou o aparecimento de casas comerciais como padarias, açougues, bares, bazares, um supermercado e hoje constata-se a existência de pequenas indústrias artesanais, contribuindo para ampliar o mercado de trabalho naquela àrea. (vide Fotos 09 e 10).

Dessa maneira, a fisionomia da Serra da Cantareira on de se localiza o Jardim Peri tem hoje outra aparēncia, ela ex pressa o que foi produzido pelo homem que para lá migrou.

o Jardim Peri é um dos inūmeros loteamentos da periferia que abriga a classe trabalhadora em condições muito precá ria, parte dela se amontoa em barracos formando as vārias fave 


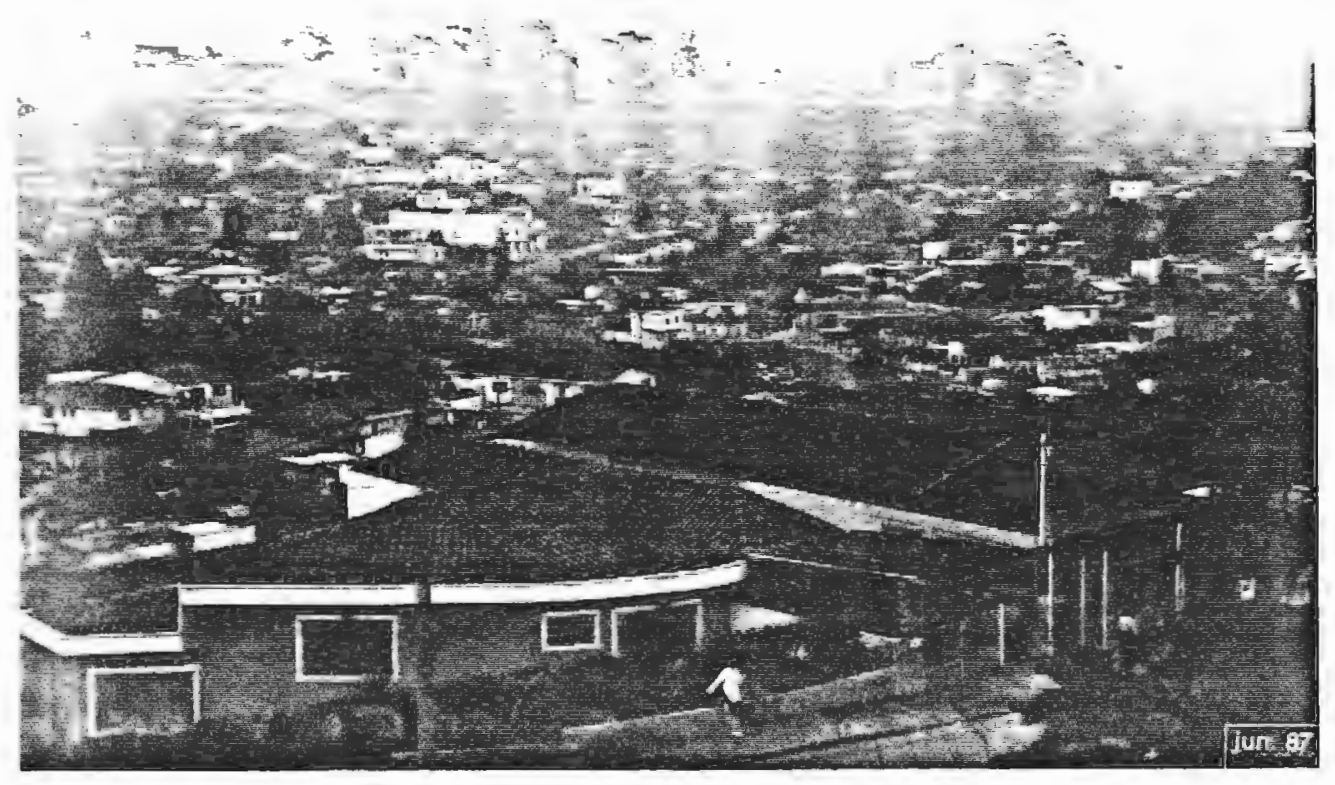

Foto 09 - Vista Geral da Area de Pesquisa - Jardim Peri

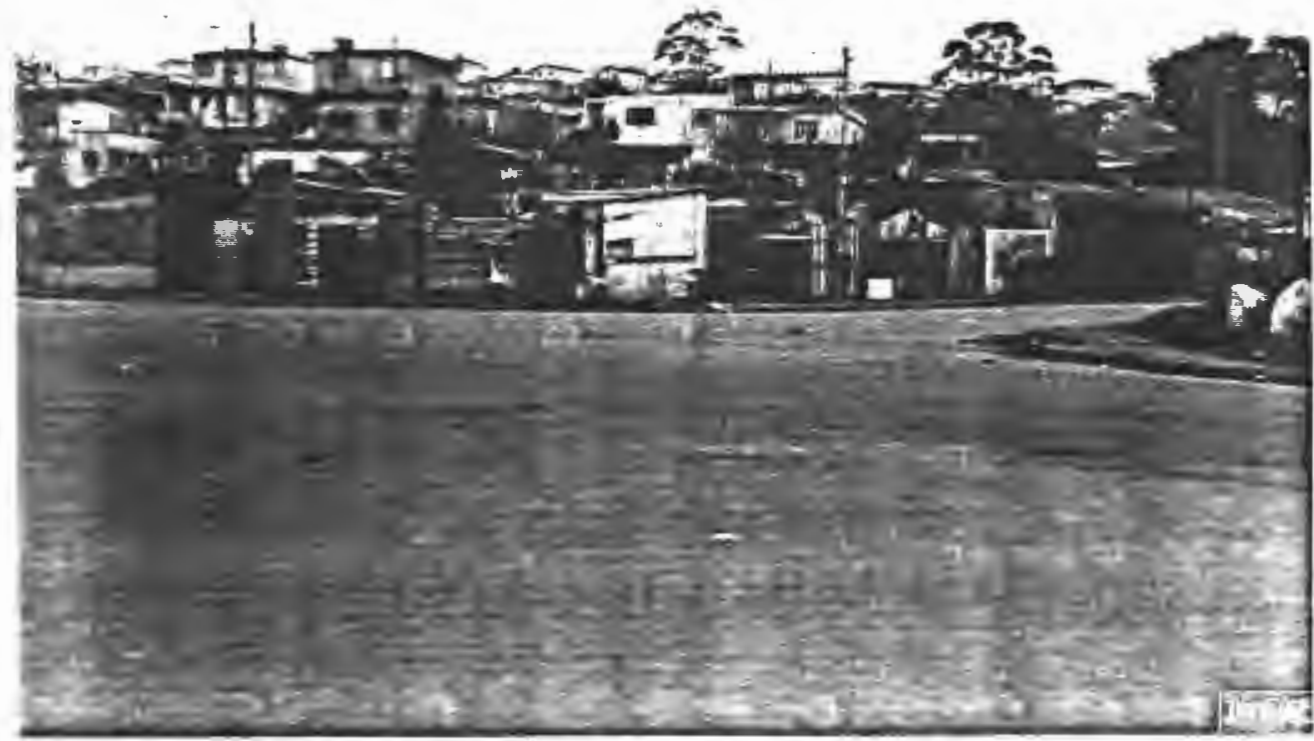

FоT0 10 - Jardim Peri (habitações precārias) 
las que existem por lá, além do trabalho e da moradia eles en frentam as sérias condições de transporte.

Lūcio Kowarick quando aborda a periferia na lógica da desordem, coloca-a como sendo a fórmula de reproduzir nas cida des a força de trabalho e consequéncia direta de desenvolvimen to económico que se formou na sociedade brasileira nas ūitimas trēs ou quatro décadas. Isto possibilitou de um lado altas taxas de exploração de trabaiho, e do outro forjou formas espo liativas que se dão ao nīvel da prōpria condição urbana de exís tēncia a que foi submetida a classe trabalhadora. E nessas à reas que está a pobreza da cidade e a de seus habitantes.

Além de todos os problemas jā abordados é importante mencionar que o depoimento de grande nümero de pais e avōs des ses alunos mostram que eles se fixaram naquele setor urbano a partir da década de 60 e a maior quantidade deles é procedente de Minas Gerais, Estados do Nordeste e interior do Estado de São Paulo; somando-se os que vieram dos värios Estados do Nordeste ultrapassam o nūmero dos mineiros.

Eles são indivĩduos que migraram para São Paulo em busca de trabalho e melhores condições, escassas na sua ārea de origem.

\subsubsection{Relações de trabalho do aluno}

Os alunos do curso noturno das escolas em estudo cons tituem na sua maioria jovens que trabalham tendo como recurso para completar sua formação as aulas que iniciam às 19 h30 e terminam às 23h05; existem aqueles cujo trabalho è distante e 
que pela dificuldade de transporte não conseguem chegar no ho rário; a alternativa encontrada foi a autorização para entra rem na segunda aula.

0 aproveitamento é pequeno, embora haja boa vontade; o cansaço é um dos fatores que impedem o maior aprendizado co mo tambëm o fato deles permanecerem presos no trabalho sob vi gilāncia do patrão cuja finalidade è a produção; ao chegarem na escola vēm naquele ambiente maior descontração, distraem se conversando com colegas, assimilando parcialmente o conteūdo das aulas. Embora tambēm o que lhes è transmitido estā dis tante do seu cotidiano representando pouco valor prático, de sencadeando o desinteresse.

Este mesmo problema nos mostra Claudio Salm (1980:35) em seu trabalho:

"... a raiz do problema da educação estā na frequen te desuinculação entre escola e trabalho...".

E comum nas $\bar{u} l$ timas aulas do período se encontrar a luno dormindo; eles levantam cedo, trabalham muitas horas du rante o dia e deitam tarde, consequentemente não possuem ener gia no final da jornada. Esta é a nossa realidade; alēm de en contrarmos professores também cansados, desestimulados pela fal ta de valorização que têm recebido; vendo-se obrigados a lecio nar em vários colégios e períodos para conseguir sobreviver.

Aprofundando dados fornecidos por eles esclarecemos que o universo desta pesquisa estā representada por 226 pessoas das quais 51 declararam que não possuem atividade remunerada, delas 175 são assalariadas, correspondendo a 77,43\% do total dos envolvidos. (vide Tabela 10). 
TABELA 10

IDADE DE INGRESSO DOS ALUNOS ENTREVISTADOS NO MERCADO DE TRABALHO

\begin{tabular}{|c|c|c|c|c|c|c|}
\hline IDADE & $\begin{array}{l}\text { EEPG PROFa. RITA } \\
\text { BICUDO PEREIRA }\end{array}$ & $\begin{array}{l}\text { EEPG PROFa. ELZA } \\
\text { SARAIVA MONTEIRO }\end{array}$ & $\begin{array}{c}\text { EEPG GUILHERME } \\
\text { DE ALMEIDA }\end{array}$ & $\begin{array}{c}\text { EEPG PROF. } \\
\text { ALFREDO GOMES }\end{array}$ & $\begin{array}{l}\text { TOTAL } \\
\text { GERAL }\end{array}$ & $\%$ \\
\hline 14 & 17 & 15 & 09 & 06 & 47 & 20,80 \\
\hline 15 & 12 & 13 & 10 & 04 & 39 & 17,26 \\
\hline 13 & 08 & 05 & 10 & 03 & 26 & 11,50 \\
\hline 16 & 01 & 13 & 03 & 05 & 22 & 9,74 \\
\hline 12 & 05 & 06 & 01 & 04 & 16 & 7,08 \\
\hline 11 & 02 & 04 & 01 & 03 & 10 & 4,43 \\
\hline 17 & 02 & 01 & 01 & 02 & 06 & 2,65 \\
\hline 10 & 01 & 0 & 02 & 01 & 04 & 1,77 \\
\hline 09 & 01 & 01 & 0 & 0 & 02 & 0,88 \\
\hline 07 & 01 & 01 & 0 & 0 & 02 & 0,88 \\
\hline 18 & 0 & 0 & 0 & 01 & 01 & 0,44 \\
\hline N. trab. & 09 & 12 & 16 & 14 & 51 & 22,57 \\
\hline TOTAL & 59 & 71 & 53 & 43 & 226 & 100,00 \\
\hline
\end{tabular}

Fonte: Questionārios aplicados - outubro/85 
Esses alunos ingressaram no mercado de trabalho no periodo compreendido entre os anos de 1975 a 1985 com idades que variaram de 7 a 18 anos. Constatamos que o inicio de traba Tho se deu cedo; 14 anos foi a idade que teve maior quantidade iniciando-se na força produtiva e isto prevaleceu no ano de 1985 com $26,55 \%$ decrescendo em 1984 com $18,41 \%$ e 1983 com $11,95 \%$. De 1980 a 1982 começaram a trabalhar $6,64 \%, 5,75 \%$ e 4,86\% dos alunos, respectivamente; no periodo anterior a porcentagem foi inexpressiva.

Ficou constatado pelas respostas obtidas que as ida des de ingresso ao trabalho variaram da maneira relacionada na tabela 10 anexa.

Tentando analisar por séries a idade que o aluno co meçou a trabalhar, em ordem decrescente, encontramos o seguinte: $26,47 \%$ da sētima sērie, $24,59 \%$ da oitava, $20,41 \%$ da sexta e $8,33 \%$ das quintas.

Na anālise dos depoimentos dos alunos em estudo cons tatamos que no inicio da vida profissional a porcentagem maior trabalhou no comércio e corresponde a $41,15 \%$ dos alunos; em se guida predominam os serviços domésticos com $12,39 \%$ e em tercei ro lugar aparece a atividade industrial com $11,51 \%$; 0 motivo da grande maioria trabalhar no comércio é pelo fato de o Jardim Peri estar próximo de Santana, bairro que tem condições de ab sorver grande quantidade de mão-de-obra pela intensa atividade comercial que possui. (Figura 15).

A concentração das atividades urbanas vai permitir o aparecimento de inūmeros empregos na ārea de serviços. A cidade que tem um contingente populacional avultado vivendo aglomera- 
PROFISSAO DOS ALUNOS POR SEXO E IDADE

TODAS AS ESCOLAS

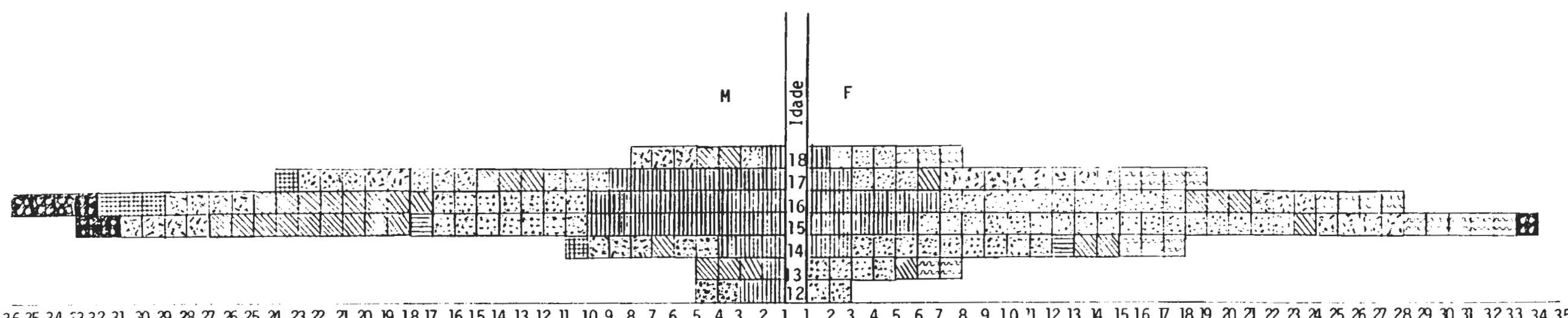

顾 Comércio - vendedor, balconista, porteiro, ajudante@ Serviços domésticos - babā, faxineira

geral, caixa

発 Não definiu profissão

NY Escritório

Construção civil - aj. jardineiro

Atividade industrial/artesanal - metalurgia,

ad Comércio ambulante - aj. feira, sorveteiro, eventual serralheiro, costureira, mecanico

FIGURA 15 
.119.

damente contribui no surgimento das necessidades de consumo da população que estimula a produção, razão de ser do comércio.

Apareceu em segundo lugar aqueles que desempenham $\underline{a}$ tividades domésticas, fazendo faxina, com contratos diārios e mensais. Estão envolvidas a î alunas de quinta a oitava séries embora o major nūmero que apareceu corresponde a alunas de o tava sērie e existe um equilíbrio desse tipo de emprego nas vá rias escolas envolvidas na pesquisa.

Com atividade industrial aparece quantidade apreciā vel de empregos e confirma a existēncia de pequenas indūstrias de confeç̧ões, bijouterias, bolsas, que absorvem enorme quantidade de braços.

Os trabalhos de escritōrio, banco, telefonista, es tão sendo atribuidos aos alunos que apresentam melhores cond $\underline{j}$ ções de instrução e responsabilidade e eles recaem naqueles que estão cursando as sēries finais de lọ grau. Na construção ci vil encontramos cinco, no comércio ambulante aparece um, como também na jardinagem e funcionalismo.

Estes menores de modo geral pertencem a famĩlias cu jos membros possuem baixo nível cultural e pouca qualificação para o trabalho, consequentemente lhes são atribuidos baixos sa lários, causa deles terem que recorrer a ajuda de todas as pes soas da casa, mesmo dos filhos que estão em idade escolar, o que ocasiona a necessidade de se transferirem para o noturno.

Esta mesma realidade observa Cortēs (1986:201):

"A necessidade de ajudar a família estā muito presen te nos seus depoimentos. Do total de menores entrevistados, 78,6\% afirmaram trabalhar para 'ajudar a 
familia'; sendo que $24,3 \%$ combinaram essa justifica tiva com explicações da ordem individual como 'gosto de trabalhar'; 'gosto de ter o meu prōprio di nheiro'; ou 'é bom trabalhar para nāo ficar à toa'; 'trabalho para comprar minhas coisas'."

De uma forma ou de outra ela constatou em seu traba Tho que as familitias de baixa renda se vēm obrigadas a lançar seus filhos menores no mercado de trabalho para suprir suas ne cessidades bāsicas.

No questionamento realizado sobre o desempenho de trabalho atual observa-se que a expectativa de melhora profissional é de todos apesar de que nem sempre conseguem o que gos tariam de fazer; sem alternativa eles se submetem ao trabalho que aparece.

As respostas revelaram que continua liderando o tra balho no comércio com $34,07 \%$. Constatamos que inūmeros deles melhoraram de situação saindo dos serviços domésticos e indo para a indústria, as respostas mostraram o crescimento para $15,05 \%$ do setor industrial e diminuindo para $9,74 \%$ os que tra bal ham em serviços domésticos.

o fato de se pensar desta forma é ocasionado por ser ele o setor de ocupação que mais foge à vigilāncia dos encargos sociais, como registro em carteira, férias, reajustes de sala rios vinculados às leis em vigor; explorando em grau mais acentuado o trabalhador.

Nos outros campos de atividade o nūmero que aparece é pequeno tornando-se pouco significativo na anālise em questão. 
Em outubro de $1985,5,30 \%$ dos alunos declararam-se de sempregados. Tambēm não havia nenhum representante no serviço público nem na profissão liberal.

Uma das questões essenciais em relação à contratação do trabalho é a existência da carteira assinada, que constitui um documento obrigatōrio inclusive para os menores. Nela são registrados data de admissão, tipo de contrato, nome do empregador ou firma, a função do empregado, a remuneração, férias e até a rescisão do contrato.

A existēncia dela corresponde a condições legais na admissão do menor no trabalho alēm de dar-lhe amparo legal em termos de direitos trabalhistas: salārio minimo, INPS, contagem do tempo para aposentadoria, fundo de garantia por tempo de serviço.

Na realidade ela é uma garantia precária de proteção no emprego em função das transgressões que ocorrem em virtude de muitos empregadores se recusarem a dar carāter legal ao con trato de trabalho; e se de fato houver exigēncia por parte do empregado ele acaba sendo despedido, motivo pelo qual se calam e continuam sendo explorados em grau ainda maior; isto também observou Cheywa Spindel em seu trabalho (1985:7):

"... tem-se muitas vezes a impressão que a explora ção do menor $\bar{e}$ muito mais o problema de ineficācia administrativa, de não obediência às normas legais, uma fiscalização facilmente corruptivel, etc.. co mo se na ilegalidade do trabalho do menor, estives se a causa de sua exploração". 
Entre os alunos em estudo $34,95 \%$ possuiam registro em carteira, $41,59 \%$ correspondiam aqueles integrantes da força pro dutiva e que estavam excluídos do contrato legal por recusa dos patrões.

Comparando-se as escolas, encontramos maior número de alunos legalmente registrados na EEPG Profa. Elza Saraiva Mon teiro: eles correspondiam a $13,71 \%$ devendo-se levar em conta que esta foi a escola onde conseguimos quantidade mais elevada de entrevistas; isto porque uma professora da casa se propós a ajudar na aplicação dos questionārios e o féz em vārios dias; nas escolas Guilherme de Almeida e Prof. Alfredo Gomes, os ques tionärios respondidos correspondem aos alunos presentes no dia da entrevista; quanto a situação da EEPG Profa. Rita Bicudo Pe reira a entrevista se estendeu por vārios dias por ser nela que eu leciono, isto deu oportunidade de abranger um número maior de alunos.

A Tabela 11 vai elucidar de forma clara a situação entre as escolas; estão na EEPG Profa. Rita Bicudo Pereira e na EEPG Profa. Elza Saraiva Monteiro o maior número de alunos menores que trabalham e não são registrados; aparecem também nas mesmas escolas o maior número daqueles que têm registro. A observação geral da tabela vai configurar uma situação de "ilegalidade" maior de menores, em relação àqueles que possuem situa ção legal.

Tentando-se avaliar por série, percebe-se que o fato do menor ser ou não um trabalhador registrado tem relação com a idade. Para as faixas de idade menor a tendēncia é de que estes alunos sejam contratados sem registro. Os que possuem situação 
TABELA 11

REGISTRO EM CARTEIRA

\begin{tabular}{|c|c|c|c|c|c|c|}
\hline AL TERNAT I VA & $\begin{array}{l}\text { EEPG PROFa. RITA } \\
\text { BICUDO PEREIRA }\end{array}$ & $\begin{array}{l}\text { EEPG PROFa. ELZA } \\
\text { SARAIVA MONTEIRO }\end{array}$ & $\begin{array}{c}\text { EEPG GUILHERME } \\
\text { DE ALMEIDA }\end{array}$ & $\begin{array}{l}\text { EEPG PROF. } \\
\text { ALFREDO GOMES }\end{array}$ & $\begin{array}{l}\text { TOTAL } \\
\text { GERAL }\end{array}$ & $\%$ \\
\hline POSSUI & 19 & 31 & 17 & 12 & 79 & 34,95 \\
\hline NAO POSSUI & 30 & 29 & 20 & 15 & 94 & 41,59 \\
\hline NÃO TRABALHA & 09 & - & - & 14 & 23 & 10,18 \\
\hline DESEMPREGADO & 01 & 11 & 16 & 02 & 30 & 13,28 \\
\hline TOTAL & 59 & 71 & 53 & 43 & 226 & 100,00 \\
\hline
\end{tabular}

Fonte: Questionārios aplicados - outubro/85 
legal são aqueles que estão cursando a sētima ou oitava sēries. Quanto aos itens, "não trabalha", "desempregado", existe um $\underline{e}$ quilíbrio entre as séries.

Levantamentos da PNAD (Pesquisa Nacional de Amostragem Domiciliar) de 1983, mostram a forma clara a negação pela contratação legal dos menores trabalhadores, a nível nacional e estadual - para cada 10 menores empregados, apenas 1,8 tem car teira assinada. Em São Paulo para cada 10 menores que trabalham 3,6 deles possuem registro.

A situação de São Paulo é levemente melhor do que a situação dos outros Estados da Federação.

Voltando à anālise da remuneração dos menores traba1 hadores $34,21 \%$ recebem ordenado entre um e um e meio salārio mî nimo, cabe observar que $22,36 \%$ que ganham menos de um salário minimo a maioria são meninas demonstrando-se a discriminação de sexo atribuindo-se às meninas menor remuneração.

Existe equilibrio entre os sexos para aqueles que re cebem um salärio. Verificou-se que os elementos que tēm ordena do superior a dois salārios minimos são doze meninos e duas me ninas e com renda maior só apareceu um rapaz.

Pode-se supor que a remuneração atribuida ao menor seja mais baixa porque a politica salarial de alguns estabelecimentos comerciais ou industriais adota o pagamento do sala rio minimo vigente. Geralmente são estabelecimentos pequenos que sofrem a politica econômica do Governo: admitem funcioná rios sem qualificação e thes atribuem baixos salārios. 
No caso do menor a situação piora: os patrões atribuem a eles qualificação inferior e os colocam nas faixas salariais mal remuneradas.

Na verdade, os irrisōrios salārios pagos a essas pes soas permite entender a presença deles no mercado de trabalho: ela contribui para a elevação da taxa de lucro das empresas e consequentemente eleva a acumulação de capital.

\subsubsection{Jornada de trabalho e forma de pagamento}

O perīodo legal do dia de trabalho conforme CLT, é de 8 horas diārias, apesar de que alguns dos incluidos nesta pes quisa declararam trabalhar um número de horas superior ao permi tido. Sabe-se que esta ē uma das maneiras de se realizar a su per-exploração, sem haver alteração salarial devida.

Dos alunos trabalhadores entrevistados $39,37 \%$ tēm um periodo de trabalho superior ao permitido significando uma so brecarga bastante alta para aquelas pessoas que continuam em a tividade, terminada a jornada de trabalho; com mudança na forma de desgaste de energia, inicialmente ele é físico e em seguida é intelectual uma vez que eles vão para a escola em busca de apren dizado diferente, confiantes que atravēs dele conseguirão pro gredir na vida e argumentam:

"Estudando eu chegarei ao meu ideal". "E dificil vencer na vida sem estudo". "Sō trabalho você não consegue emprego melhor".

Eles depositam grande confiança no que a escola possa Thes oferecer, alēm da atividade social que ela é para essa ju ventude. No ambiente escolar eles encontram liberdade, segurança, 
e oportunidade de fazer inūmeras amizades.

o trabalho preenche o dia do aluno e limita seu horá rio de estudo, não sobrando praticamente tempo de lazer.

Para exemplificar pedimos a alguns alunos a descrição do seu dia. Eis um exemplo:

Walter, 17 anos, diz:

"Acordo 6h40, escovo os dentes, troco de roupa, pego minha mochila, ponho minha marmita e saio para tra balhar, pego o ônibus e vou até santana para o ser viço, entro 8hoo, ponho minha roupa de trabalho, co loco minha marmita na geladeira e começo a trabalhar. Eu trabalho na Otica Voluntārios; eu trabalho com lente de óculos. As 12 hoo eu vou almoçar, depois às 13 hoo volto ao trabalho a mesma coisa com lente de óculos, às 18 hoo eu vou trocar de roupa e vou embo ra. Pego o ônibus, venho de pé até minha casa. Tomo banho, janto, pego meu material e vou para a escola. Eu estudo das $19 h 30$ às $23 h 00$ e vou para casa dormir. Eu ganho salārio minimo".

Esse sacrificio tem objetivo "para melhorar na vida"e a ünica forma de vencē-lo estā na conquista do conhecimento que a escola vai lhe dar, por isso colocam todo empenho para conciliar os dois: trabalho e escola porque "sem trabalho não vivo e sem escola não progrido", conforme depoimento do aluno.

Na realidade uma atividade constitui empecilho para outra, isto dá para constatar também na fala da menina Andréia, 14 anos.

"Trabalho no Jardim Peri, acordo às 6 h20 e saio de casa 6h50; entro no trabalho à 7h00, trabalho numa bábrica de lençol, sou arrematadeira. Paramos às 
$9 h 00$ para tomar cafje entramos às $9 \mathrm{~h} 15$. Tenho uma hora de almoço e saio às 6 hoo da tarde, de segunda a sexta".

0 relógio passa a ser o fiscal constante para que 0 compromisso seja efetuado no horário previsto.

0 mundo de compromisso desses alunos - trabalhadores quer escolar ou no serviço são preenchidos de regulamentos que os obrigam a agir.

Constatamos outro exemplo quando na reunião de entre ga das avaliações do segundo bimestre de 1988 perguntamos à mãe do Adriano Luiz, 13 anos, aluno da 5 á série do perīodo no turno, qual o motivo da constante ausência do menino às aulas, e uma das causas do baixo aproveitamento que ele vinha apresen tando.

0 relato efetuado pelo próprio aluno que estava na companhia de sua mãe nos surpreendeu.

"Eu trabalho na casa da Esfiha, sou entregador, mais faço muitas coisas mais, trabalho na copa, vendo sor vete no balcão, etc. A minha hora de trabalho na semana $\bar{e}$ das $8 h 00$ às $18 h 00$ e eu acordo às 7hoo. No fim de semana (sexta, sābado e domingo) eu trabalho das $8 h 00$ da manhã às 10 h00 da noite e nesses dias tenho 15 minutos de almoço. Eu ganho $c z \$ 15.000,00$ e tenho uma folga na semana. 0 dinheiro que eu ga nho é lōgico que é pra dar em casa, mais eu bico com $C z \$ 5.000,00$.

Este aluno faltava toda sexta-feira para trabalhar e às vezes tambēm na segunda-feira, só que por cansaço.

E claro que o aproveitamento escolar fica bastante prejudicado, é impossível alguém que tenha tido uma jornada de 
intensa atividade física conseguir grande aprendizado na esco la, que é a tarefa que se segue; o cansaço fỉsico impede que o bom aproveitamento aconteça.

Edmundo, 14 anos, 5 a sērie, tambēm descreve:

"Eu trabalho de segunda a sābado na Folha de São Pau lo, acordo de madrugada, às 4 hoo da manhä para tra balhar; sou jornaleiro, chegando no serviço pego um tanto de jornal e saio para vender, quando acabo vol to para prestar contas. As $2 h 00$ da tarde eu almoço no serviço mesmo, porque em casa não dā tempo. Saio as $14 h 30$ e vou direto para a escola, estudo das $15 h 00$ as 19h00; tem dia que eu perco a hora da esco la.

Recebo $C z \$ 15.000,00$ por mês, pego vale todo dia 22. só tenho o domingo para me divertir".

A jornada de trabalho desses aluncs varia bastante, embora prevaleça a de 8 horas, sendo $27,43 \%$ aqueles que indica ram o nūmero de horas trabalhada. E importante também mencionar os que desempenham 10 horas diārias que são $14,16 \%$, como tam bēm é notável os que trabalham 9 horas, correspondendo a $10,62 \%$.

A anālise por sērie mostra que os trabalhadores com jornada maior estão cursando as ūitimas sēries.

No ponto abordado sobre a forma de pagamento prevale ceu a mensal com um indice de $61,06 \%$, os diaristas são em me nor nümero e correspondem a $6,19 \%$ porque ē prātica desse tipo de pagamento os trabalhos de pedreiros e domésticas que apare cem em pequena proporção. Incluidos na designação "outros"(sig nificando produção, tarefa, quinzena) existem $6,64 \%$.

Essa forma de pagamento é pequena no processo produtivo em que eles estão inseridos. 
3.3.3. Esperança do progresso e necessidade de traba

lho

Prosseguindo nossa investigação ficou claro que to dos expressam vontade de subir na escala social, uns permanecen do no emprego que estão porque gostam; a grande maioria objeti va outras atividades embora para que isso aconteça sejam necessários cursos específicos; eles são $61,06 \%$ e demonstram através da vontade de conseguir melhor salário, com o intuito de ver sa tisfeita maior quantidade de suas necessidades.

Entre as razões que eles apontam como causas das mu danças prevalece a de gostar da profissão pretendida e se in cluem aqui $19,03 \%$ das opções; $13,28 \%$ mostram que a sua escol ha está voltada para aquela que dá mais dinheiro, 12,83\% expressa ram que o trabalho pretendido é "melhor" e que é "uma maneira de crescer". Neste questionamento encontramos $23,45 \%$ sem res ponder e as demais opiniões são em número reduzido.

Os encargos mais pretendidos estão no setor terciārio representados por: piloto, bancārio, escritōrio, professor, ma nequim, investigador, boy, digitador, enfermeira e outros. Eles correspondem à vontade de $34,08 \%$ dos alunos, em seguida a parecem os interessados no setor industrial que são $8,40 \%$ cu jas profissões ambicionadas são mecānico, metalūrgico, serraTheiro, operador de máquina, técnico geral, eletrōnica; em ter ceiro lugar aparece o serviço público, com uma porcentagem de $5,31 \%$, em seguida vem a profissão liberal com $3,98 \%$ e os servi ços domésticos com $0,44 \%$.

A necessidade de ajudar a famīi ia é bastante presen- 
te no relato dos menores, $58,41 \%$ dos 226 que responderam o ques tionārio declararam que seu ordenado compõe o orçamento mensal da familia, 46,44\% correspondem aqueles que ajudam nas despesas em geral como, compra de alimentação, pagamento de aluguel, luz, āgua, $7,52 \%$ compram a limentação, $1,33 \%$ pagam aluguel, $0,44 \%$ co laboram na manutẹção da casa, 2,22\% são aqueles que ganham pa ra si. (vide Tabela 12 ).

Outros informaram sua ajuda à famīlia de outra forma, a í significa economia familiar e não remuneração; a partir do momento que eles assumem as tarefas domésticas liberando outro membro da casa para o trabalho assalariado, ou ajudando o pai em seu comércio, dispensando a contratação de um empregado, des ta maneira participam da reprodução da famîlia, embora de for ma indireta.

Para a maioria deste grupo social a motivação fundamental do seu trabalho é a necessidade de contribuir de alguma forma na renda familiar. São poucos os que justificaram seu trabalho como independēncia, ou mesmo vontade de assumir seus custos.

Como observa Cortes $(1986: 203):$

"... ao se considerar a estrutura familiar, mais es pecificamente a da familia das classes trabalhadoras urbanas, sob o ponto de vista da produção capi talista e da reprodução da força-de-trabalho, é pos sivel desvendar essa ambigllidade dos depoimentos dos menores a respeito da necessidade de seu traba lho. ou seja, a instituição familiar sob o modo de produção capitalista, no processo de reprodução da força de trabalho, participa dos mecanismos para tanto - acionados, na medida em que se encarrega da 
TABELA 12

SITUAÇAOO DOS ENTREVISTADOS QUANTO A CONTRIBUIÇAOO NO ORÇAMENTO FAMILIAR

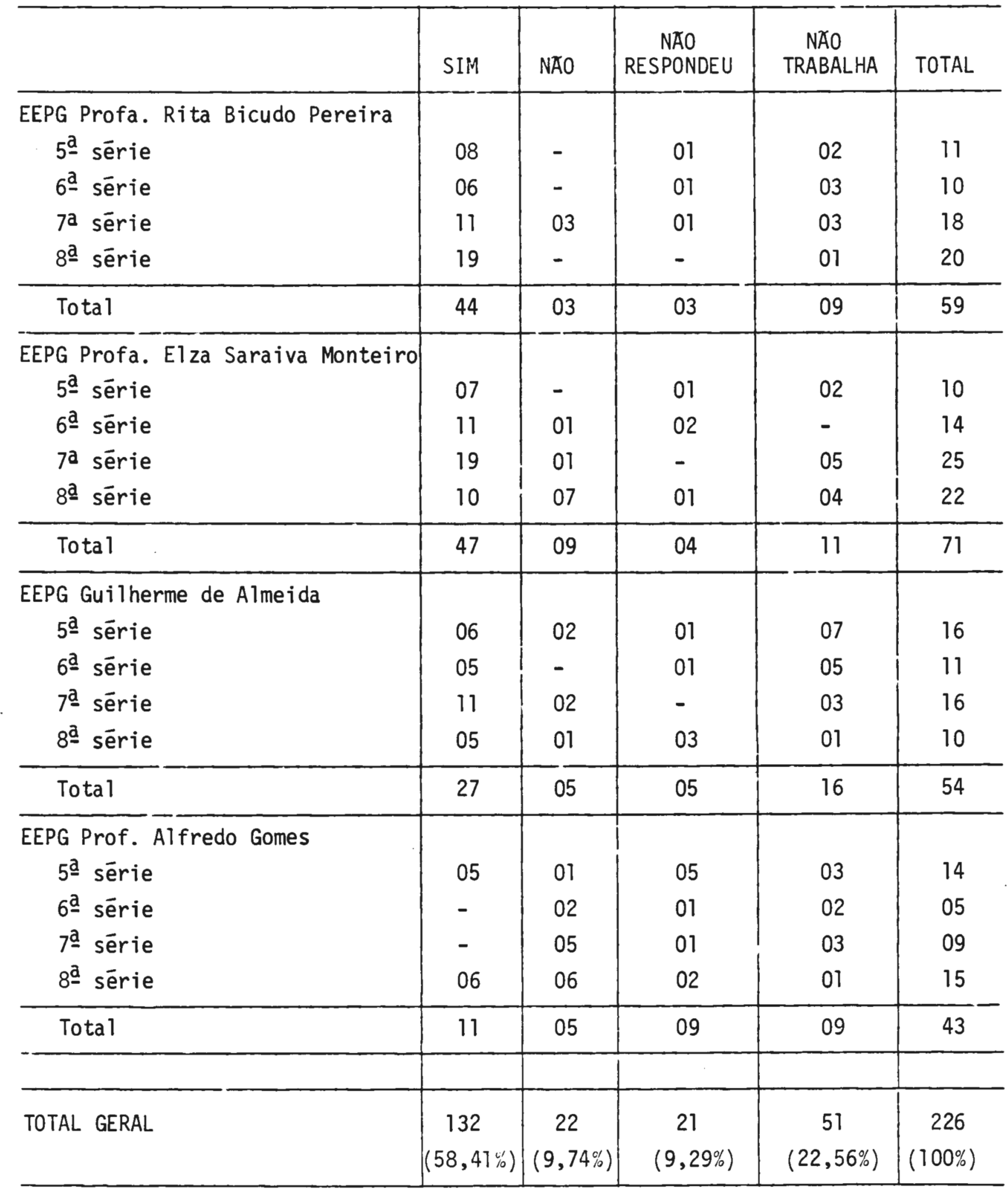

Fonte: Questionārios aplicados - Outubro/85 
sobrevivência/manutenção dos trabalhadores adultos

$e$ da jormação de novos trabalhadores jovens".

A anālise por sērie se assemelha ao que jā foi expos to. Terminado o relato daqueles que mostraram vontade de mudar de atividade para progredir, encontramos $11,50 \%$ que declararam estar contentes com o que fazem, em seguida aparece $22,57 \%$ que representam os desempregados e os que nunca trabalharam, não responderam $4,87 \%$.

Quando se tenta entender o trabalho do menor no âmbi to das relações familiares, é necessārio se levar em conta a situação da famīlia e é importante analisā-la, para se verificar os motivos delas terem lançado seus filhos ainda em forma ção no mercado de trabalho.

Naturalmente é o processo produtivo que ao definir o nivel de vida das familias thes atribuem compromissos reais e que para verem solucionados, recorrem ao trabalho dos filhos me nores.

A famỉlia, enquanto fornecedora de força de trabalho tem sofrido diretamente o impacto das transformações sociais, a deteriorização das condições de vida das famīilas das classes trabalhadoras ocasionadas pelo baixo poder aquisitivo do chefe de familia, a alta constante do custo de vida, obrigam a inser ção do menor no mercado de trabalho.

$\mathrm{Na}$ mesma linha de constatação Gouveia menciona, em sua pesquisa que realizou em São Paulo e Santo André em 1981, $(1982: 9)$ : 
".. o trabalho precoce não decorre necessariamente da desagregação familiar ou do fato de o menor pro vir de uma familia incompleta. O que explica a en trada da criança ou do adolescente no mercado de trabalho, na maioria dos casos, são, antes, as dí ficuldades financeiras decorrentes dos baixos ren dimentos dos adultos".

Entretanto em termos de grupo familiar, a entrada do menor no mercado de trabalho cria uma situação paradoxal. De um lado seu salário colabora para a elevação da renda familiar. De outro ele passa a ser concorrente do trabalhador adulto e a desvalorizā-lo; uma vez que trabalha o mesmo número de horas e recebe valor mais baixo do que os pagos aos adultos.

Quando se constata c rebaixamento do padrão de vida e a constante queda real dos salários, a famīila assume a car ga de reproduzir a força de trabalho para o capital, numa si tuação criada por ele.

\subsubsection{O trabalho e o rendimento escolar}

Ao tentar analisar os caminhos do dia a dia dos nos sos alunos do curso noturno ficamos conhecendo as amargas es tratégias por eles efetuadas, na vontade de consequir melhor situacão na sociedade. Assumir a situação de estudar e trabalhar para o jovem significa enfrentar inúmeros problemas. Ati vidade remunerada integrada $\bar{a}$ vida do menor que estuda tem si do considerada dificil de ser vivida principalmente se for por muito tempo.

os compromissos do trabalho acabam sendo empecilho pa ra o aproveitamento normal dentro da escola e como o poder a 
quisitivo desses alunos è restrito, a escolaridade não é prío ridade e eles acabam por abandonā-la, inicialmente por perīodo temporārio com intenção de retomā-la dentro das possibilidades.

Apesar de na atualidade se pretender a democratização do ensino e mesmo que isto possa representar uma abertura para trabalhadores e seus filhos, a escola continua seletiva uma vez que no seu interior ela distribui diferentemente o saber dada a dificul dade das vārias āreas da sociedade de absorver os ensinamentos. Des ta forma permanecer na escola é dificil; o menor trabalhador a ela se dirige esgotado, cansado, atē o momento que consegue um diploma, sem haver formação adequada para a sua profissão ou a caba desistindo de estudar.

Dada a relevāncia do fato é importante a anālise en tre a intenção trabalho-escola e como ela acontece na vida des ses estudantes.

Os dados em estudo, obtidos nas escolas pesquisadas, são alguns dos indicadores dos conflitos desse cotidiano; eles se referem aos anos de 1984, 1985 e 1986, a escola deste perīo do está ligada ao ano de 1985 quando foram aplicados os questionārios.

0 referencial corresponde às tarefas que indicam a composição das escolas em março, nelas constam o ano, o período que no caso refere-se ao noturno, o horārio de funcionamento do curso, nūmero de classes, total de alunos matriculados em cada série e total geral em 31 de março. As tabelas seguintes referem-se à realidade no decorrer do ano relatando: afastamen to por transferēncia, evadidos, retidos por frequéncia, retidos por avaliação, promovidos e matrícula total. o número geral 
em dezembro difere do indicado em março ocasionado pelas matrị culas e transferēncias ocorridas durante o ano. Esse histōrico compreende o período letivo de março a dezembro.

A tabela 13 nos demonstra que a EEPG Profa. Rita Bicu do Pereira teve um nūmero de matrículas em março de 1984 no cur so noturno de 73 alunos para a 5 a série do primeiro grau que foram distribuidas em duas classes. No decorrer do ano houve transferēncias, matrículas, evadidos, retidos por frequência, retidos por avaliação e promovidos; em dezembro a situação era a seguinte: $58,54 \%$ de alunos que não foram promovidos, alguns deles nem chegaram a avaliação final e ocorreu da seguinte forma: 18 e vadidos, 18 retidos por frequencia, 12 retidos por avaliação, num total de $48(58,54 \%) ; 4$ foram transferidos e 30 corresponde ao número de promovidos correspondendo a $36,59 \%$. No ano de 1985 a situação apresentou pouca variação embora tenha aumenta do para $58,82 \%$ o nūmero daqueles que permaneceram na mesma sé rie; sendo 18 os evadidos, 19 os retidos por frequencia e 13 os retidos por avaliação num total de 50 alunos, este resultado é de dezembro para uma matrícula de 79 alunos em março que forma vam duas classes; neste ano nas quintas sēries a promoção foi de $36,48 \%$ correspondendo a 31 alunos. Continuando a anāijse na mesma série no ano de 1986 constatamos que em março o número de matriculas aumentou e isto ocorreu de forma gradativa nos trēs anos em anālise; no mesmo ano os reprovados e evadidos so maram 61 correspondendo a $71,76 \%$; as promoções baixaram para $24,72 \%$ correspondendo a 21 , e os alunos transferidos foram $3,52 \%$.

0 que ocorreu nestes trēs anos em relação à 5 a sērie do primeiro grau foi grande procura em março, aumentando o nū 
TABELA 13

EEPG PROFa. RITA BICUDO PEREIRA

RENDIMENTO ESCOLAR DOS ALUNOS - 5a SERIE

\begin{tabular}{c|c|c|c|c|c|c}
\hline $\begin{array}{c}\text { 5- } \text { a SERIE } \\
\text { MATRICULA/MARÇ0 }\end{array}$ & ANO & CLASSES & EVASA0-RE TIDOS & PRONOVIDOS & TRANSFERIDOS & $\begin{array}{c}\text { MATRICULA } \\
\text { TOTAL }\end{array}$ \\
\hline 73 & 1984 & 2 & $48-58,54 \%$ & $30-36,59 \%$ & $4-4,87 \%$ & $82-100 \%$ \\
79 & 1985 & 2 & $50-58,82 \%$ & $31-36,48 \%$ & $4-4,70 \%$ & $85-100 \%$ \\
81 & 1986 & 2 & $61-71,76 \%$ & $21-24,72 \%$ & $3-3,52 \%$ & $85-100 \%$ \\
\hline
\end{tabular}

Fonte: Dados fornecidos pela escola. 
mero de participantes todos os anos, o mesmo ocorreu com a eva são embora tenha sido mais acentuada no ano de 1986; as promo ções diminuiram de ano para ano e em 1986 baixaram de forma significativa.

Para as sextas sēries a situação é semelhante, vamos encontrar grande nümero de matrīculas em março com mais alunos em 1985; quanto à evasão notamos que ela começa a diminuir em relação à quinta sērie, apesar de ser alta tambēm e apresenta maior elevação em 1986; a situação de dezembro mostra que as promoções decresceram entre 1984 a 1986. (vide Tabela 14)

Os argumentos alegados corresponderam aos empecilhos que à vida de um trabalhador impõem: "repeti três anos; sou co brador de ônibus e o horārio não dā pra chegar", "estava fraco, não ia dar desisti", "motivo de trabalho, não dā para chegar nem na segunda aula".

Encontramos uma certa estabilidade nas sētimas e oị tavas séries no nümero de alunos existentes no decorrer do ano, as evasões diminuem sensivelmente e se tornam ainda menor no último ano do curso. (vide Tabelas 15 e 16).

Essa mesma realidade é constatada por Cortes (1986: 317), em seu trabalho sobre o menor na cidade de Araraquara:

"... é plausivel referir-se ao atraso escolar dessa população assim como à evasão escolar existente".

A forma mais direta para eu saber o motivo da desistência de estudar foi procurar esses alunos em casa e perguntar ao menor porque parou de estudar, dessa maneira constatei tam bém até que ponto o trabalho interfere na formação educacional desses jovens. 
TABELA 14

EEPG PROFa. RITA BICUDO PEREIRA

RENDIMENTO ESCOLAR DOS ALUNOS - 6- SERIE

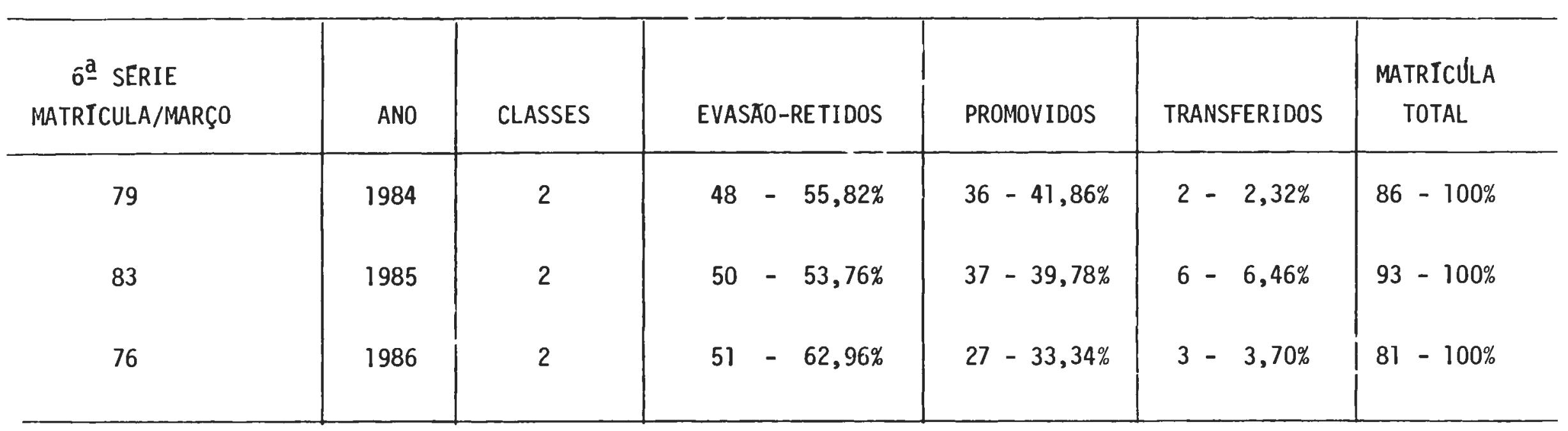

Fonte: Dados fornecidos pela escola 
TABELA 15

EEPG PROFa. RITA BICUDO PEREIRA

RENDIMENTO ESCOLAR DOS ALUNOS - 7a SERIE

\begin{tabular}{|c|c|c|c|c|c|c|}
\hline $\begin{array}{c}7^{\text {a }} \text { SERIE } \\
\text { MATRICULA/MARÇO }\end{array}$ & ANO & CLASSES & EVASAO-RETIDOS & PROMOVIDOS & TRANSFERIDOS & $\begin{array}{c}\text { MATRICULA } \\
\text { TOTAL }\end{array}$ \\
\hline 71 & 1984 & 2 & $27-36,49 \%$ & $43-58,11 \%$ & $4-5,40 \%$ & $74-100 \%$ \\
\hline 76 & 1985 & 2 & $29-34,93 \%$ & $54-65,07 \%$ & $0-$ & $83-100 \%$ \\
\hline 71 & 1986 & 2 & $26-36,61 \%$ & $41-57,75 \%$ & $4-5,64 \%$ & $71-100 \%$ \\
\hline
\end{tabular}

Fonte: Dados fornecidos pela escola 
TABELA 16

EEPG PROFa. RITA BICUDO PEREIRA

RENDIMENTO ESCOLAR DOS ALUNOS - 8 a SERIE

\begin{tabular}{|c|c|c|c|c|c|c|}
\hline $\begin{array}{c}\text { 8 } \stackrel{\text { a }}{\text { SERIE }} \\
\text { MATRICULA/MARÇO }\end{array}$ & ANO & CLASSES & EVASAO-RETIDOS & PROMOVIDOS & TRANSFERIDOS & $\begin{array}{l}\text { MATRICULA } \\
\text { TOTAL }\end{array}$ \\
\hline 62 & 1984 & 2 & $16-25,39 \%$ & $46-73,02 \%$ & $1-1,59 \%$ & $63-100 \%$ \\
\hline 72 & 1985 & 2 & $19-25,00 \%$ & $57-75,00 \%$ & - & $76-100 \%$ \\
\hline 76 & 1986 & 2 & $16-20,77 \%$ & $58-75,34 \%$ & $3-3,89 \%$ & $77-100 \%$ \\
\hline
\end{tabular}

Fonte: Dados fornecidos pela escola. 
As explicações dadas pela desistēncia da escola refé rem-se na sua maioria a empecilhos ocasionados pelo trabalho : "horärio de trabalho, não dava para chegar nem na segunda aula". "cansaço do trabalho", "estava fraco não ia dar para passar de sisti". "estava fraco porque brincava muito", "repeti três ve zes e desisti", "isto porque trabalhava por turno e na semana que era escalado para tarde e noite não ia na aula", "não con seguia aprender matemática". Um ponto sobre o qual me parece importante chamar a atenção è que o aluno coloca sobre si a culpa de "ter baixo aproveitamento", da "dificuldade de aprender", do "não querer estudar", etc. Foram poucos os que decla raram que a "a aula não era interessante", "o professor não sa bia ensinar".

outras razões são freqdentemente mencionadas como es gotamento físico, cansaço; alguns ainda colocaram o fato de ter muito sono e dormir na aula, porque trabalhavam pesado o dia todo.

A realidade da EEPG Profa. Elza Saraiva Monteiro é semelhante a da escola relatada anteriormente; a evasão nas quintas e sextas sēries é grande melhorando nas sétimas e se estabilizando nas oitavas. (vide Tabelas 17 a 20).

A escola no ano de 1984 contava com 105 alunos matri culados na quinta série do curso noturno, no mês de março, cu ja divisão deu origem a trés classes. No decorrer do ano vamos constatar a evasão de 35 deles e 20 ficaram retidos por avalia ção, eles correspondem aos alunos que de uma forma ou de outra não conseguiram ir para a série seguinte e representam $51,87 \%$ das classes, os promovidos são $41,53 \%$ e vai aparecer $6,60 \%$ que 
se transferiram.

No ano de 1985 vamos encontrar duas quintas sēries e 72 alunos: essa redução se deve a uma seleção feita pela dire ção da escola; não foram aceitos os desistentes do ano anterior, como também aqueles que sō deram problemas disciplinares e não apresentaram aproveitamento nos estudos; a evasão desse ano nessa série foi de $62,95 \%$ correspondendo aos evadidos, re tidos por avaliação e retidos por frequéncia, os promovidos fo ram $27,18 \%$ e vai aparecer a transferéncia de $3,87 \%$ da classe.

Como a evasão das quintas sēries foi grande, no ano de 1986 a direção da escola resolveu ampliar o número de classes das primeiras séries e criar no noturno o curso supletivo, iniciando o funcionamento de uma primeira e de uma segunda sē ries. A direção da escola achou viável essa mudança por preten der maior aproveitamento por parte da clientela, o que não vị nha ocorrendo com as quintas séries cujos alunos alēm de não apresentarem aproveitamento davam inúmeros problemas de disciplina. A única quinta série que ficou apresentou no decorrer do ano alto indice de evasão correspondendo a 18 alunos, e 3 fo ram retidos por avaliação: vemos aí constatado um ỉndice de $52,5 \%$ da classe que não conseguiram dar continuidade aos seus estudos; foram promovidos $45 \%$ do total e aparece uma transferên cia. Comparando-se os trēs anos encontramos baixo indice de a provação no ano de 1985 melhorando sensivelmente em 1986; tal fato se deve à seleção da clientela.

Relatamos informações obtidas na escola sobre o pro cedimento adotado para se tentar melhorar o aproveitamento da quela clientela: a maneira encontrada para não prejudicar os 
que tinham interesse em estudar foi excluir os indisciplinados.

Até que ponto constitui acerto a atitude adotada ou estaria a escola funcionando como örgão reprodutor de desigual dades sociais?

Partindo-se do pressuposto que esses alunos indisciplinados sejam oriundos de familias desagregadas ou incomple tas, de que forma poderiamos exigir deles o que nunca aprenderam? Ou estaria a escola se desencumbindo da tarefa de educar?

As sextas sēries dessa escola nos anos que estão sen do investigados tiveram duas classes, em 1984 o nümero de alu nos era de 71 , em 1985 aumentaram para 77 e em 1986 diminuiram para 65; a relação dos desistentes e dos retidos por avaliação ou por frequência diminuiram em relação à sērie anterior e cres ceram as porcentagens de promoções que foram $65,29 \%$ em 1984 , $51,83 \%$ em 1985 e $53,74 \%$ em 1986 .

Nas sētimas sēries vamos encontrar uma estabilidade maior tanto quanto ocorreu na escola anterior, o nūmero de alu nos evadidos e retidos diminui como nos mostra a tabela a se guir.

A evasão e reprovação nesta escola foi maior nesta sērie em relação a EEPG Profa. Rita Bicudo Pereira; as aprova ções cresceram em 1984 e 1986.

No ūl timo ano do curso a situação é mais estável, o número de matrículas de março se equilibra com as aprovações de dezembro, as evasões e reprovações são pequenas. 
TABELA 17

EEPG PROFa. ELZA SARAIVA MONTE IRO

RENDIMENTO ESCOLAR DOS ALUNOS - 5- SERIE

\begin{tabular}{c|c|c|c|c|c|c}
\hline $\begin{array}{c}5-\text { a }- \text { SERIE } \\
\text { MATRICULA/MARÇO }\end{array}$ & ANO & CLASSES & EVASA0-RETIDOS & PROMOVIDOS & TRANSFERIDOS & $\begin{array}{c}\text { MATRICULA } \\
\text { TOTAL }\end{array}$ \\
\hline 105 & 1984 & 3 & $55-51,87 \%$ & $44-41,53 \%$ & $7-6,60 \%$ & $106-100 \%$ \\
72 & 1985 & 2 & $51-62,95 \%$ & $22-27,18 \%$ & $8-9,87 \%$ & $81-100 \%$ \\
\hline 38 & 1986 & 1 & $21-52,50 \%$ & $18-45,00 \%$ & $1-2,5 \%$ & $40-100 \%$ \\
\hline
\end{tabular}

Fonte: Dados fornecidos pela escola 
TABELA 18

EEPG PROFa. ELZA SARAIVA MONTEIRO

RENDIMENTO ESCOLAR DOS ALUNOS - 6- SERIE

\begin{tabular}{|c|c|c|c|c|c|c|}
\hline $\begin{array}{l}6-\text { a SERIE } \\
\text { MATRICULAS/MARÇO }\end{array}$ & ANO & CLASSES & EVASAOO-RETIDOS & PROMOVIDOS & TRANSFERIDOS & $\begin{array}{l}\text { MATRICULA } \\
\text { TOTAL }\end{array}$ \\
\hline ו1 & 1984 & 2 & $22-30,55 \%$ & $47-65,29 \%$ & $3-4,16 \%$ & $72-100 \%$ \\
\hline 77 & 1985 & 2 & $37-44,56 \%$ & $43-51,83 \%$ & $3-3,61 \%$ & $83-100 \%$ \\
\hline 65 & 1986 & 2 & $30-44,77 \%$ & $36-53,74 \%$ & $1-1,49 \%$ & $67-100 \%$ \\
\hline
\end{tabular}

Fonte: Dados fornecidos pela escola 
TABELA 19

EEPG PROFa. ELZA SARAIVA MONTEIRO

RENDIMENTO ESCOLAR DOS ALUNOS - $7 \stackrel{\text { a }}{\text { SERIE }}$

\begin{tabular}{c|c|c|c|c|c|c}
\hline $\begin{array}{c}7^{\mathrm{a}} \text { SERIE } \\
\text { MATRICULA/MARÇ0 }\end{array}$ & ANO & CLASSES & EVASAO-RETIDOS & PROMOVIDOS & TRANSFERIDOS & $\begin{array}{c}\text { MATRICULA } \\
\text { TOTAL }\end{array}$ \\
\hline 70 & 1984 & 2 & $16-22,87 \%$ & $52-74,28 \%$ & $2-2,85 \%$ & $70-100 \%$ \\
74 & 1985 & 2 & $36-45,55 \%$ & $37-46,86 \%$ & $6-7,59 \%$ & $79-100 \%$ \\
72 & 1986 & 2 & $31-40,78 \%$ & $43-56,59 \%$ & $2-2,63 \%$ & $76-100 \%$ \\
\hline
\end{tabular}

Fonte: Dados fornecidos pela escola 
TABELA 20

EEPG PROFa. ELZA SARAIVA MONTEIRO

RENDIMENTO ESCOLAR DOS ALUNOS - 8a SERIE

\begin{tabular}{|c|c|c|c|c|c|c|}
\hline $\begin{array}{c}8 \stackrel{a}{a} \text { SERIE } \\
\text { MATRICULA/MARÇO }\end{array}$ & ANO & CLASSES & EVASA0-RETIDOS & PROMOVIDOS & TRANSFERIDOS & $\begin{array}{l}\text { MATRICULA } \\
\text { TOTAL }\end{array}$ \\
\hline 55 & 1984 & 2 & $10-17,23 \%$ & $47-81,05 \%$ & $1-1,72 \%$ & $58-100 \%$ \\
\hline 61 & 1985 & 2 & $16-25,80 \%$ & $41-66,14 \%$ & $5-8,06 \%$ & $62-100 \%$ \\
\hline 56 & 1986 & 2 & $15-26,31 \%$ & $42-73,69 \%$ & - & $57-100 \%$ \\
\hline
\end{tabular}

Fonte: Dados fornecidos pela escola 
Minha investigação na residência dos desistentes da EEPG Profa. Elza Saraiva Monteiro revelou a mesma realidade já constatada: "trabalho até às $20 h 00$ não dā para chegar", "indis ciplina, recebi transferência", "dificuldade em matemātica", "co mecei namorar meu pai me tirou da escola", "trabalho longe".

A anālise efetuada corresponde à realidade do Jardim Peri, a sequéncia da investigação vai abordar escolas que se localizam em setores vizinhos, cuja finalidade é averiguar se existe semelhança nos fatos ocorridos.

Constatei que na EEPG Guilherme de Almeida nesses trēs anos o número de alunos matriculados em cada uma das sé ries foi muito maior do que nas escolas descritas, ela contou com organização de classes que variou de 4 a 6 por série, como demonstram as tabelas $21,22,23$ e 24 .

A sequéncia da realidade desta escola se assemelha às duas anteriores. Apresenta um nūmero grande de matrīculas em março e no decorrer dc ano ocorre evasão e reprovação grande; sendo que este fenômeno é maior nas quintas sēries diminuindo na sexta e se estabilizando nas sētimas e oitavas séries.

As entrevistas feitas nas casas dos desistentes reve laram um quadro semelhante aos que já foram colocados; as tabe las 25 a 28 referem-se a realidade da EEPG Prof. Alfredo Gomes.

A realidade desta escola é constituida de 242 alunos do curso noturno no ano de 1984 , eles estavam distribuidos em duas classes por série, nesse anonas quintas séries, houve uma evasão de $58,22 \%$ sendo que 28 correspondiam aos evadidos e 18 os retidos por avaliação, foram promovidos $32,92 \%$ e 7 se trans feriram correspondendo a $8,86 \%$; essas classes em março tinham 
TABELA 21

EEPG GUILHERME DE ALMEIDA

RENDIMENTO ESCOLAR DOS ALUNOS - 5- SERIE

\begin{tabular}{l|c|c|c|c|c|c}
\hline $\begin{array}{c}5-\text { a } \\
\text { METRICULA/MARÇO }\end{array}$ & ANO & CLASSES & EVASAO-RETIDOS & PROMOVIDOS & TRANSFERIDOS & $\begin{array}{c}\text { MATRICULA } \\
\text { TOTAL }\end{array}$ \\
\hline 216 & 1984 & 6 & $189-80,28 \%$ & $44-18,88 \%$ & $2-0,84 \%$ & $236-100 \%$ \\
207 & 1985 & 6 & $121-64,01 \%$ & $64-33,88 \%$ & $4-2,11 \%$ & $189-100 \%$ \\
178 & 1986 & 5 & $123-69,11 \%$ & $54-30,33 \%$ & $1-0,56 \%$ & $178-100 \%$ \\
\hline
\end{tabular}

Fonte: Dados fornecidos pela escola. 
TABELA 22

EEPG GUILHERME DE ALMEIDA

RENDIMENTO ESCOLAR DOS ALUNOS - 6- SERIE

\begin{tabular}{|c|c|c|c|c|c|c|}
\hline $\begin{array}{c}\text { 6- } \text { - SERIE } \\
\text { MATRICULA/MARÇO }\end{array}$ & ANO & CLASSES & EVASAOO-RETIDOS & PROMOVIDOS & TRANSFERIDOS & $\begin{array}{l}\text { MATRICULA } \\
\text { TOTAL }\end{array}$ \\
\hline 188 & 1984 & 5 & $160-72,07 \%$ & $57-25,68 \%$ & $5-2,25 \%$ & $222-100 \%$ \\
\hline 162 & 1985 & 5 & $85-52,48 \%$ & $73-45,06 \%$ & $4-2,46 \%$ & $162-100 \%$ \\
\hline 200 & 1986 & 6 & $133-66,5 \%$ & $67-33,50 \%$ & - & $200-100 \%$ \\
\hline
\end{tabular}

Fonte: Dados fornecidos pela escola 
TABELA 23

EEPG GUILHERME DE ALMEIDA

RENDIMENTO ESCOLAR DOS ALUNOS - 7 7 - SERIE

\begin{tabular}{l|c|c|c|c|c|c}
\hline $\begin{array}{c}7-\text { SERIE } \\
\text { MATRICULA/MARÇO }\end{array}$ & ANO & CLASSES & EVASAO RETIDOS & PROMOVIDOS & TRANSFERIDOS & $\begin{array}{c}\text { MATRICULA } \\
\text { TOTAL }\end{array}$ \\
\hline 151 & 1984 & 5 & $81-51,92 \%$ & $71-45,52 \%$ & $4-2,56 \%$ & $156-100 \%$ \\
157 & 1985 & 5 & $60-60,0 \%$ & $36-36,0 \%$ & $4-4,0 \%$ & $100-100 \%$ \\
157 & 1986 & 5 & $90-57,34 \%$ & $66-42,03 \%$ & $1-0,63 \%$ & $157-100 \%$ \\
\hline
\end{tabular}

Fonte: Dados fornecidos pela escola 
TABELA 24

EEPG GUILHERME DE ALMEIDA

RENDIMENTO ESCOLAR DOS ALUNOS - 8 - SERIE

\begin{tabular}{l|c|c|c|c|c|c}
\hline $\begin{array}{c}\text { 8- } \text { - SERIE } \\
\text { MATRICULA/MARÇ0 }\end{array}$ & ANO & CLASSES & EVASA0-RETIDOS & PROMOVIDOS & TRANSFERIDOS & $\begin{array}{c}\text { MATRICULA } \\
\text { TOTAL }\end{array}$ \\
\hline 136 & 1984 & 4 & $62-37,80 \%$ & $100-60,99 \%$ & $2-1,21 \%$ & $164-100 \%$ \\
118 & 1985 & 4 & $31-25,40 \%$ & $89-71,97 \%$ & $2-1,63 \%$ & $122-100 \%$ \\
139 & 1986 & 4 & $35-25,19 \%$ & $102-73,38 \%$ & $2-1,43 \%$ & $139-100 \%$ \\
\hline
\end{tabular}

Fonte: Dados fornecidos pela escola 
TABELA 25

EEPG PROF. ALFREDO GOMES

RENDIMENTO ESCOLAR DOS ALUNOS - 5- SERIE

\begin{tabular}{c|c|c|c|c|c|c}
\hline $\begin{array}{c}5-\text { a } \text { SERIE } \\
\text { MATRICULA/MARÇO }\end{array}$ & ANO & CLASSES & EVASA0-RETIDOS & PROMOVIDOS & TRANSFERIDOS & $\begin{array}{c}\text { MATRICULA } \\
\text { TOTAL }\end{array}$ \\
\hline 62 & 1984 & 2 & $46-58,22 \%$ & $26-32,92 \%$ & $7-8,86 \%$ & $79-100 \%$ \\
75 & 1985 & 2 & $39-49,36 \%$ & $37-46,85 \%$ & $3-3,79 \%$ & $79-100 \%$ \\
83 & 1986 & 2 & $68-72,34 \%$ & $16-17,03 \%$ & $10-10,63 \%$ & $94-100 \%$ \\
\hline
\end{tabular}

Fonte: Dados fornecidos pela escola 
TABELA 26

EEPG PROF. ALFREDO GOMES

RENDIMENTO ESCOLAR. DOS ALUNOS - 6 ㅡㄴ SERE

\begin{tabular}{c|c|c|c|c|c|c}
\hline $\begin{array}{c}\text { 6- SERIE } \\
\text { MATRICULA/MARÇ0 }\end{array}$ & ANO & CLASSES & EVASAO-RETIDOS & PROMOVIDOS & TRANSFERIDOS & $\begin{array}{c}\text { MATRICULA } \\
\text { TOTAL }\end{array}$ \\
\hline 66 & 1984 & 2 & $36-45,0 \%$ & $41-51,25 \%$ & $3-3,75 \%$ & $80-100 \%$ \\
71 & 1985 & 2 & $58-78,37 \%$ & $14-18,93 \%$ & $2-2,70 \%$ & $74-100 \%$ \\
79 & 1986 & 2 & $55-65,47 \%$ & $24-28,58 \%$ & $5-5,95 \%$ & $84-100 \%$ \\
\hline
\end{tabular}

Fonte: Dados fornecidos pela escola 
TABELA 27

EEPG PROF. ALFREDO GOMES

RENDIMENTO ESCOLAR DOS ALUNOS - 7ㄹ SERIE

\begin{tabular}{|c|c|c|c|c|c|c|}
\hline $\begin{array}{c}7^{\mathrm{a}} \text { SERIE } \\
\text { MATRICULA/MARÇO }\end{array}$ & ANO & CLASSES & EVASAO-RETIDOS & PROMOVIDOS & TRANSFERIDOS & $\begin{array}{l}\text { MATRICULA } \\
\text { TOTAL }\end{array}$ \\
\hline 60 & 1984 & 2 & $27-38,57 \%$ & $41-58,58 \%$ & $2-2,85 \%$ & $70-100 \%$ \\
\hline 51 & 1985 & 2 & $37-71,15 \%$ & $15-28,85 \%$ & - & $52-100 \%$ \\
\hline 39 & 1986 & 1 & $23-57,5 \%$ & $15-37,5 \%$ & $2-5,0 \%$ & $40-100 \%$ \\
\hline
\end{tabular}

Fonte: Dados fornecidos pela escola 
TABELA 28

EEPG PROF. ALFREDO GOMES

RENDIMENTO ESCOLAR DOS ALUNOS - 8르 SERIE

\begin{tabular}{|c|c|c|c|c|c|c|}
\hline 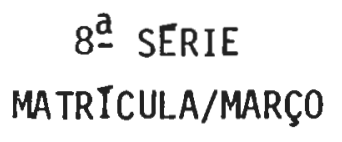 & ANO & CLASSES & EVASAO-RETIDOS & PROMOVIDOS & TRANSFERIDOS & $\begin{array}{l}\text { MATRICULA } \\
\text { TOTAL }\end{array}$ \\
\hline 54 & 1984 & 2 & $16-30,76 \%$ & $36-69,24 \%$ & - & $52-100 \%$ \\
\hline 45 & 1985 & 2 & $20-44,44 \%$ & $20-44,45 \%$ & $5-11,11 \%$ & $45-100 \%$ \\
\hline 20 & 1986 & 1 & $4-20,0 \%$ & $15-75,0 \%$ & $1-5,0 \%$ & $20-100 \%$ \\
\hline
\end{tabular}

Fonte: Dados fornecidos pela escola 
62 alunos. Em 1985 a matrīcula em março aumentou para 75 alunos e a evasão diminuiu para $49,36 \%$, 35 eram os evadidos e 4 os re tirados por avaliaçãc, transferidos nesse ano aparecem 3,79\%. Em 1986 as matrículas em março foram de 83 alunos embora suba bastante a evasão para $72,34 \%$ cuja situação correspondia a 56 evasōes, 1 retido por frequéncia e 11 retidos por avaliação, os promovidos foram $17,03 \%$ e houve 10 transferēncias. 0 ano de de 1986 teve maior nūmero de matrīculas em março como tambēm ocorreu uma grande quantidade de evasões e reprovações, o nūme ro de aprovados foi o mais baixo do periodo em anālise. Nas sextas séries encontramos matrículas em março suficiente para formar duas classes em 1984, a evasão desta sērie foi de $45,0 \%$ incluídos os alunos retidos por avaliação, os promovidos foram $51,25 \%$ e transferidos houve 3. No ano de 1985 para 71 matrículas em março tivemos $78,37 \%$ entre retidos e evadidos; porcenta gem muito alta; a promoção contou com 18,93\% quantidade peque na pelo número de alunos que passaram pela escola no decorrer do ano; para 1986 vamos constatar 79 matrículas em março, duas classes formadas; em dezembro aparece $65,47 \%$ de alunos que per maneceram na mesma sērie incluindo retidos e evadidos, as pro moções contaram com $28,58 \%$.

Na sētima sērie as matrículas em março vão variar, em 1984 aparecem 60 matriculados que formaram duas classes; no a no seguinte são 51 os alunos no começo do ano, que também de ram origem a 2 classes; em 1986 aparecem 39 alunos que forma ram uma classe, os alunos evadidos baixaram em relação ao ano anterior, embora continuasse alto o número de promoções. 
rie, nos dois primeiros anos aparece em março 54 e 45 alunos que formam 2 classes, em 1986 esse número se reduz para 20 de saparecendo uma classe, melhora o indice de aprovação e a de sistēncia no decorrer do ano diminui.

As questões apontadas como causa da desistēncia nes sa escola revelam que a sua clientela refletem ser, alguns de les, originārios de famīlias desagregadas ou mesmo provir de famỉlias incompletas.

A maneira tribulenta e mesmo grosseira de se relacio narem, demonstra pessoas que nunca tiveram em casa alguém que os orientasse sobre a forma mais acertada de se relacionar com os colegas ou mesmo com superiores que os orientam dentro da escola.

Quando estive nesta escola para aplicar os questionā rios tive oportunidade de observar isso como também alguns de les de forma pouco delicada negaram a responder às questões, embora fosse esclarecido que eles não eram obrigados a fazê-lo.

Quando percorri a casa dos desistentes para questionar a causa do abandono do estudo ouvi as seguintes respostas: "trabalho, e o lugar que passo para chegar em casa é perigoso" (favela), "não tinha condição de comprar material", "pai bale ceu, tive que trabalhar e o horārio não dā para chegar", "saí porque no ambiente escolar havia muita indisciplina".

Os dados apresentados mostram que a evasão escolar no noturno é muito grande como tambēm a repetēncia, mais acentuada nas $5 \underline{a \underline{S}}$ e $6 \underline{a} \underline{S}$ sēries; para as $7 \underline{a} \underline{S}$ e $8 \underline{\text { aS }}$ a situação muda, $\underline{e}$ xiste uma estabilidade maior na frequéncia e cresce o número de aprovações. 
A trajetōria percorrida para se entender algumas at $\underline{i}$ tudes praticadas pelos menores estudantes do periodo noturno da periferia nos leva a uma série de reflexões sobre os conflitos no valor da escola para o menor estudante e o retorno dado pe10 mercado.

Ficou constatado que a clientela em estudo faz parte de familias de trabalhadores que tēm necessidade, para completar o orçamento familiar, lançar seus filhos menores e estudan tes no mercado de trabalho, cuja finalidade é colaborar nas des pesas e assumir alguns gastos pessoais.

Constatação anterior nos leva a concluir que quando se propõem a conciliar escola e trabalho inúmeras barreiras $\underline{a}$ parecem.

Esses alunos saem de casa muito cedo, enfrentam con dução geralmente lotada, trabalham o dia todo, no fim da tarde de volta só têm tempo de tomar um banho, pegar o material e ir para a aula. São poucas as condições que lhes sobram para o a prendizado; fatigado e sem coragem o ūnico interesse que 1 hes sobra è a satisfação do encontro com amigos além do ambiente se guro que a escola lhes oferece para que desenvolvam um cîrculo melhor de amizades.

Com o decorrer dos meses surgem as primeiras avaliações, mediante os resultados eles se desencantam, tentam mais um perĩodo, embora a recuperação seja difícil pela falta de tempo disponỉvel para estudar, além da fadiga e tempo hábil pa ra chegar no início do perỉodo, colaborem para a situação se tornar cada vez pior e acabam desistindo da escola com esperan ças de poder recomeçar no ano seguinte. 
Não há opção: o trabalho precisa ser mantido como lem bra Carvalho (1985:35):

"... o aluno do curso noturno só $\bar{e}$ aluno porque tra balha. E pelo fato de estar trabalhando ou procu rando trabalho que ele se matricula na escola".

o mercado de trabalho urbano seja ele no comércio ou na indústria exige cada vez mais dos indivĩduos qualificação pa ra o desempenho dos cargos que possam oferecer.

O jovem se vê pressionado a se matricular na escola afim de conseguir o emprego e continua nela com o objetivo de melhorar na função que passa a desempenhar.

Isto se deve ao fato de se julgar que a tarefa de es colarização prepara o indivíduo para desempenhar melhor o car go que ocupa, embora saibamos que o trabalho bloqueia, trunca ou mesmo encerra a trajetōria educacional do menor.

Informações estatỉsticas divulgadas pelo IBGE sobre a ūitima década como tambēm os dados do PNAD dos ūitimos anos têm mostrado crescente incorporação de menores de idade no mercado de trabalho, observa-se elevação dos nīveis de escolaridade como também tem aumentado a quantidade de menores que trabalham e estudam.

Dando sequéncia aos questionamentos procurei obter informação sobre a importância do estudo e do trabalho na vida das pessoas em anālise.

0 resultado das opiniões de todas as escolas incluin do-se anālise por série para detectar a maturidade do aluno, ob tivemos grande ênfase da importāncia do conhecimento obtido na escola para vencer na vida; possibilitando em termos futuros, 
melhor emprego ou mesmo subir de cargo no trabalho em que es tão.

0 resultado correspondeu a $57,08 \%$ representando a $\underline{0}$ pinião de 129 alunos; só na sexta série que predominou: "ambos são importantes - trabalho e estudo".

Obtivemos alguns comentārios que os ensinamentos es colares são pouco utilizados no desempenho de suas funções de trabalho, eles ajudam de forma geral, alegaram que não é preci so estudar para trabalhar e que o desempenho da função melhora com a prātica.

Em segundo lugar, correspondendo a $36,37 \%$ das op $\underline{\mathbf{i}}$ niões num total de 83 alunos, apareceu ambos (trabalho e estu do são importantes); os que deram essa resposta justificaram suas razões ressaltando o valor da dependēncia uma da outra: "sem trabalho não como e sem estudo não subo no emprego". Vèse aqui um ciclo vicioso, preenchido de problemas ocasionados por se tentar desempenhar as duas atividades.

Os problemas enfrentados pelo menor representam in cumbencias dificeis de carregar. No trabalho eles são os ele mentos chaves nas relações sociais de produção; no estudo, pe los ensinamentos recebidos, eles constituem objeto de reprodução da ideologia dominante face à necessidade social no preparo da força de trabalho.

Valorizando só o estudo tivemos $25,22 \%$ correspondendo a opinião de 57 alunos e se obteve deles as expressões: " estudo é importante para poder ter uma profissão melhor", "pa ra melhorar na vida", "para prevenir o juturo". 
Dando importāncia só ao trabalho a porcentagem de va lor é pequena $(5,31 \%)$ e se justificaram nas frases "trabalho pa ra me sustentar", "é muito importante".

Foi abordado também como questão importante no dia a dia do estudante trabalhador a distāncia que ele tem que percor rer de casa ao trabalho e de casa até à escola.

0 local do emprego da maioria dessas pessoas estā dís tante do Jardim Peri de oito a dez quilometros; $18,58 \%$ fazem es se trajeto, predominando alunos de sétimas e oitavas séries.

Distantes do trabalho de cinco a sete quilometros apa recem alunos com 14 anos de idade representantes de quintas e sextas séries; trabalhando no Jardim Peri existem $16,37 \%$.

Em relação ao trajeto que eles fazem para chegar na escola é pequeno, a maioria desses estudantes mora nas proximidades dela: para $67,70 \%$ dos alunos, suas casas estão a quinhen tos metros da escola; até mil metros existem $17,70 \%$. A porcenta gem que tem dois quilometros de distāncia é pequena $(4,87 \%)$ e trajeto superior é inexpressivo. Convēm lembrar que essas dis tâncias são feitas a pé. Via de regra a condução que esses alu nos utilizam frara chegar ao trabalho é ōnibus: 44,69\% deles uti lizam só ōnibus; trabalhando perto e que dispensam transporte são 19,47\%; tendo necessidade de tomar ōnibus e metrō existe uma por centagem de $10,62 \%$; as demais formas de locomoção como bicileta, moto são insignificantes. Utilizando-se de duas conduções encon tramos $8,85 \%$. E bastante expressivo o nūmero de alunos que de $\underline{j}$ xaram de mencionar como chegam ao local de trabalho. 
A pergunta sobre a frequēncia à escola fora do horá rio de aula, $83,63 \%$ responderam que isso não ocorre por ques tões óbvias, eles trabalham e não possuem tempo livre para fa $z \bar{e}-10$. Constata-se que a experiēncia social desses menores é bastante restrita, influenciada pela condição de trabalhador.

Quando acontece situação inversa, isto è, alunos que estão em férias do trabalho, ou aqueles cujo expediente é meio periodo ocorre que não existe espaço livre que eles possam ut $\underline{i}$ lizar no prédio da escola isto porque elas funcionam com hora aula das 7 hoo às 23 hlo não possibilitando nem a utilização da quadra, porque o barulho perturba o andamento das aulas. 0 pe rỉodo disponivel da área escolar para a comunidade ocorre nos fins de semana: ē por isso que vai aparecer $43,75 \%$ frequentan do a escola no domingo e $25,0 \%$ no sábado, eles vão participar de treinos, organizam jogos amistosos e às vezes campeonato.

Foi indagado sobre o que eles mais apreciavam na es cola: 44,26\% revelou que é da atenção e do tratamento dado pe los professores; $25,24 \%$ expressaram sua afeição pelos colegas, interesse nos diālogos e troca de idéias que ocorre nos intervalos e recreios; apareceu também um grupo de $10,49 \%$ que gosta dos ensinamentos que recebem.

Surgiu uma porcentagem de $5,90 \%$ que gostavam da qua dra para se divertir e 3,93\% tinham interesse por um pouco de tudo; em pequena proporção apareceram aqueles a quem agradavam conversar com as meninas, os passeios organizados na escola, a diretora, as festas, o espaço aberto para criatividade; surgiram inclusive os que não gostavam de nada. 


\subsubsection{Relaçöes aluno-escola-trabalho}

A escola procura desenvolver no aluno a capacidade de pensar, analisar e interpretar de forma critica a realidade que - cerca. Essa realidade é o todo que envolve a sociedade e natu reza; cabe ao professor levar o aluno a compreender o espaço pro duzido pela sociedade.

Para que isso aconteça é necessārio ele entender as relações entre os homens na produção dos bens materiais.

Existe uma divisão acentuada entre trabalhador manual e o intelectual; o ensinamento transmitido ao trabalhador-estudante na escola tem pouca relação com a sua prática de trabalho.

A nossa sociedade estabelece divisões no saber, a pra xis escolar está voltada para a formação global do estudante, segundo ela pretende dar ao estudante o necessārio para se rela cionar com o grupo à medida que the for cobrado segundo seu àm bito de relações.

Dessa forma ela funciona como seletora daqueles que por motivo de trabalho, ou mesmo de grupo social lhes faltam con dições de assimilação atravēs dessa prātica ela distribui dife rentemente o saber.

Quando o aluno procura um emprego exige-se dele estú do para entrar, embora na prātica não vā utilizā-lo. Tambēm pa ra que haja estabilidade no trabalho e progresso na carreira é exigido que ele prossiga nos estudos.

A prática do ensinamento na escola difere daquela da da no trabalho; na sala de aula a matéria é transmitida pelo 
professor para um grupo de 35 a 40 alunos e é a prova que vai avaliar se o aluno aprendeu ou não, a sua aprovação é determinada pela média dos quatro bimestres. Isto não ocorre no empre go quando se admite um empregado, o encarregado ensina o servi ço e ele já vai executando o trabalho, o chefe fiscaliza e cor rige os erros e aos poucos a tarefa vai saindo melhor.

Jā ficou constatada a importāncia que o aluno-trabalhador dá ao estudo depositando nele a esperança de melhorar sua posição na escala social embora existam outros motivos da frequência à escola além da:

"... crença de que a extensão da escolaridade $\bar{e}$ im portante para a obtenção de um bom emprego para progredir na vida".

como coloca Gouveia (1983:7). Eles deixam claro que gostam do periodo de escolaridade porque existem outros elementos que 0 tornam agradável; a escola é o ponto de encontro com os amigos, - local onde trocam idéias de forma descontrajida como também onde se relacionam com as meninas.

o ensino noturno é a única opção para o trabalhador pois os depoimentos obtidos mostram que o serviço lhe foi im posto por necessidade familiar ou até mesmo para se manter.

Existe uma condição social especial, um horārio dife rente que de uma forma aparente pretende lhe fornecer condições de igualdade no grupo, embora seja bastante discriminatória quan do tudo isso ocorre em função da posição que o estudante do no turno desempenha no processo produtivo.

0 conteūdo desenvolvido no noturno é limitado: ele é organizado de acordo com as condições de assimilação da classe 
esses alunos enfrentam uma tarefa intelectual apōs um dia de trabalho intenso e por muitó otimista que se seja o seu apren dizado é pequeno. Também nos mostra Carvalho (1985:35):

"... em sintese, ensina-se menos $\bar{a}$ noite, exige-se menos e reprova-se mais".

O cotidiano permeado de conflitos não é percebido pe 10 trabalhador estudante que ao terminar sua jornada de traba Tho dirige-se para a escola em busca do saber, cansado, mal a limentado e nem sempre consegue aprender.

Mediante as avaliações e à constatação do resultado negativo, ele se desestimula, desiste antes do final do ano pa ra não sofrer humilhação com a reprovação; diante de tantos pro blemas ele se atrasa e perde na competição do mercado de traba 1ho e passa a ser mais explorado.

Sua presença no processo produtivo significa a subs tituição do trabalhador adulto para o mesmo desempenho embora a intenção seja the atribuir pouca qualificação e reduziro seu salário. 
CONSIDERAÇOES FINAIS 


\section{CONSIDERAÇOES FINAIS}

De acordo com o que foi colocado como objetivos no inicio deste trabalho, buscamos investigar as condições reais existentes entre estudo e trabalho do menor; as relações entre escola e o processo produtivo; a importāncia do trabalho do me nor para a sociedade e sua participação para complementação da renda familiar.

Reflexões efetuadas sobre as investigações obtidas nos questionários e depoimentos dos alunos mostram-nos alguns fatos importantes.

E maior o número de menores que participam do proces so produtivo por necessidade de complementar a renda familiar, ocasionada pela baixa remuneração de seus pais, do que os alu nos que trabalham para si, ou mesmo daqueles que efetuam tal prática para conseguir prestígio em seu meio social. Ficamos sabendo que os familiares desses alunos são migrantes do Esta do de Minas Gerais e dos Estados Nordestinos, na sua grande maioria atraídos pela idéia do "amplo" mercado de trabalho que a cidade de São Paulo ofereceria, a partir da década de 1960, mo mento em que a

"... Metrópole constitui importante mediação no pro cesso de integração entre a economia do pais $e$ mercado internacional". (1986:1)

Migraram em busca de trabalho e se fixaram no Jardim Peri como em outras āreas da periferia da cidade de São Pauto, única opção de moradia para famîlias de baixa renda.

Quanto à prātica do trabalho e do estudo ficou evi 
denciado que eles são incompatĩveis, não apresentando os alunos aproveitamento escolar satisfatório.

Constatou-se que o trabalho do menor contribui para a criação de riqueza, inicialmente para o empregador, e num senti do mais amplo para todo o processo produtivo. Ele é um elemento importante no desempenho de tarefas consideradas simples, libe rando o trabalhador adulto para atividades mais complicadas, ou mesmo tirando o emprego do trabalhador adulto que passa a ser desempregado, porque o salārio atribuĩdo ao menor é mais baixo.

Tornou-se evidente que sua participação no mercado de trabalho consome grande nūmero de horas de sua vida, fato que ele aceita como condição necessāria e com resignação.

No que se refere à escola, ficou constatado que nos cursos noturnos que atendem ao estudante trabalhador, exige - se menos dos alunos, porque existe falta de condição física e men tal para assimilação dos conteúdos formais, após longa jornada de trabalho.

A estruturação do curso noturno não sensibilizou ainda as autoridades educacionais, no sentido de construir uma es cola eficaz para esse aluno menor, duplamente penalizado.

Como nos mostram Silva, T.R. e Nogueira, M.J. no ca derno nọ 1 "Curso Noturno um Desafio" (Fundação Carlos Chagas, pg. 6), a educação brasileira não é tão democrática quanto pare ce ao mencionarem que:

"... - A expansão da escolarização joi conseqllència, principalmente, da industrialização acelerada do país nas ültimas décadas. Havia necessidade de tra balhadores que soubessem ler instruçōes, calcular, entender a propaganda dos meios de comunicação". 
Elas continuam relatando no caderno no 3 , pg. 40 e 41 que:

"... ninguém nega a existência de fatores extra esco lares que concorrem para o fracasso escolar: a ca rência alimentar, a carência cultural, as condições de renda da familia",

como tambēm que as escolas carentes se caracterizam por ter:

"... maior nūmero de turnos, maior número de sēries superlotadas, jornadas diārias mais curtas, menor estabilidade do corpo docente".

A evasão escolar é muito alta como pudemos constatar na tabela fornecida pelas escolas. Ela acontece em decorrēncia de toda dificuldade que o estudante trabalhador enfrenta quan do tenta conciliar o processo produtivo ao estudo, cujo resultado culmina com o baixo rendimento escolar: o estudante, por causa do resultado negativo, desiste da escola. Ficou constata do que este fato ocorre com maior frequéncia no Jardim Peri en tre os alunos de quinta a oitava sēries do curso noturno.

E importante se pensar em um curso para trabalhadores com conteūdo ligado à sua prática, e que apresentem flexibilidade a fim de que eles tenham condições e interesse em frequen tā-10.

Como jā foi colocado, a instituição escolar estā produzindo no seu interior o elemento propicio ao capital. Sua proposta de igualdade é aparente, quando passamos a ter conhecimento que os ensinamentos não são distribuidos na mesma pro porção para todos os que nela se matriculam. 
Apesar da teoria da reprodução social não ser mais a ceita por inūmeros teōricos ligados à educação, ela existe na periferia da cidade de São Paulo, a partir do momento em que os conteūdos são preparados na proporção que os alunos têm con dição de assimilar.

Dessa forma, a condição social define a separação da escola em duas redes de ensino: a que forma os operários e a que reproduz a burguesia.

As razões para os cursos noturnos precisam ser encon tradas também fora da escola, no sentido de se construir uma "nova" escola; a forma de trabalho também precisa ser questionada, uma vez que o trabalho desses alunos é necessārio para a sobrevivência da famîlia.

Das observações efetuadas, temos como consequência que os alunos do curso noturno saem da escola sem qualificação especīfica ou técnica, indo ocupar uma situação inferior na hie rarquia salarial, em decorrēncia de terem frequentado cursos $\underline{e}$ laborados com conteūdos que eles não tiveram condições de ass $\underline{i}$ milar; desta forma são alunos que apresentam conteūdo formal re duzido como consequência de sua própria histōria de vida e de trabalho.

A exemplo disto encontramos uma reportagem de Ana Fro mer publicada pela Folha de São Paulo de 06.11.88, no caderno de Educação e Ciência, pg. 8, onde a autora coloca algumas mu danças que a Secretaria da Educação do Estado de São Paulo pre tende colocar em prātica a partir de 1989, e cuja intenção é facilitar a aprovação em cursos noturnos de São Paulo. 
No cronograma de anteprojeto, é proposta da Secreta ria implantar um curso de um mês, em janeiro, cujo interesse è recuperar o conteúdo anual que o aluno não aprendeu. Esta pró posta seria aplicada somente para duas disciplinas: se o aluno for reprovado, ele irā para as chamadas turmas de desdobramento, onde serā dado reforço nas disciplinas onde ele não conse guiu ser aprovado. A escola terá que reorganizar sua carga ho rāria para atender esses alunos, isto nas quintas e sextas sé ries; para as sétimas e oitavas, pretende-se criar o regime de dependēncia.

Coloca a autora que:

"A preocupação com a educação e conseqlientemente com a qualidade de ensino parece estar cada vez mais dis tante da Secretaria de Educação do Estado de São Pau lo".

prossegue:

"... A bandeira da 'educação é um direito de todo cí dadão' esqueceu-se de que a qualidade dessa educação é fundamental para que o preceito seja vālido".

A partir de toda realidade apresentada, $\bar{e}$ evidente que os salārios a eles atribuĩdos serão reduzidos, embora essas pessoas tenham por aspiração melhorar sua vida e acreditem ob ter esta ascensão social atravēs da conclusão do curso que es tejam frequentando.

Depositam no diploma adquirido na escola a esperança de se colocarem no mercado de trabalho com remuneração satisfa tória e digna para se manterem. 
E importante mencionar a ideologia imposta a essas pessoas, que vēem na escola a resolução de seus problemas e a oportunidade de progredirem socialmente.

No que se refere ao processo produtivo, a atual si tuação traz vantagens ao empregador, pois a partir do momento em que esses jovens são lançados no mercado de trabalho sem condi ções de grandes exigēncias, submetem-se aos salārios irrisōrios que 0 mercado lhes oferece. Tal situação beneficia o empregador que consegue obter maior lucro em cima do menor trabalhador.

No momento atual, em que sērios problemas afetam a sociedade brasileira, hā necessidade de se criar uma pedagogia que transforme a realidade concreta atual que está gerando in justiças.

Diz Florestan Fernandes (1985:5):

"O Educador, $\bar{e}$ aquele que trabalha realmente ao lado do estudante, $\bar{e}$ aquele que tenta conhecer a realida de concreta e transformā-la a partir de seus alunos. Por a $\bar{i}$ estā o espaço que precisa ser ganho".

E de fundamental importāncia ligar-se o trabalho efe tuado no interior da sala de aula à comunidade. Nōs, professores, não temos condição de avaliar todo relacionamento humano que se processa no ambiente escolar e fora da sala de aula, que tambēm constituem aprendizado de vida.

Atravēs do esclarecimento crítico para avaliação da nossa realidade social, devemos procurar estender o processo de mudança tambēm fora da escola, na sociedade como um todo, a fim de que a filosofia educacional no Brasil reformule os parā metros da função construtiva da Educação na sociedade brasile ra. 
A transformação implica na responsabilidade de todos que serā conseguida atravēs de movimentos sociais, por intermē dio de diālogos frutíferos, buscando-se atravēs da negociação os beneficios que se pretendem.

Só atravēs da luta social é que conseguiremos a trans formação da sociedade brasileira err uma sociedade democrātica, e para que isto ocorra o professor é chamado a participar des te trabalho que também é político. 
BIBLIOGRAFIA 
- AB'SABER, Aziz N. - "0 Sïtio urbano de São Paulo". In: A cidade de São Paulo. Estudos de Geografia urbana. São Paulo, Nacional, 1958, v.l.

- Afanassiev, V.g. - "Filosofia Marxista". Rio de Janeiro, Vi. tōria, 1963 .

- ALVIM, Maria Rosilene B. - "0 trabalho infantil e reprodução social" - o trabalho das crianças numa fäbrica com vila o perāria". Rio de Janeiro, IFCF/UFRJ, 1981 (mimeografado).

- ANTUNIASSI, Maria Helena R. - "Trabalhador infantil e escolarização no meio rural". Rio de Janeiro, Zhar, 1983.

- ARRUDA, Rivaldo S.V. - "0 processo de estigmatização do menor e sua função ideológica". São Paulo, CERU, s.d. (mimeo grafado).

- ASARI, Alice Y. - "Produtores e processadores do rami-0 caso de Londrina - PR. "São Paulo, dissertação de mestrado, USP, 1984 (mimeografado).

- ASSOCIAÇAOO DOS GEOGRAFOS BRASILEIROS - "Teoria e método da geografia". Borrador 1, São Paulo, AGB, 1982.

- BECKER, Bertha K. - "As migrações internas no Brasil, reflexo de uma organização do espaço desequilibrada". In: Revista Brasileira de Geografia". Rio de Janeiro, IBGE, 1968, ano 30, nọ 2 .

- BitTencourt, Circe Maria - "A escola püblica em diferentes momentos da Histōria do Brasil. A escola püblica hoje". São Paulo, s.d. (mimeografado). 
- BRANDAO, Carlos R. (org.) - "Repensando a pesquisa partici pante". 2- ed. São Paulo, Brasiliense, 1985.

- BRESCIANI, Maria Stella M. - "Lōgica e Dissonāncia - Socieda de de trabalho: Lei, Ciēncia, Disciplina e Resistência $0-$ perāria". In: Revista Brasileira de História. São Paulo, set. $1985 / \mathrm{fev} .1986$, v.6.

- Carvalho, Célia Pezzolo - "Ensino noturno, realidade e ilusão" São Paulo, Cortez, Coleção Polēmicas do Nosso Tempo, nọ 12, 1985 .

- CASTElls, Manuel - "A Questão Urbana", trad. Arlene Caetano, Rio de Janeiro, Paz e Terra, 1983.

- CHAUI, Marilena - "0 que é Ideologia" 9 $\underline{a}$ ed., São Paulo, Bra siliense, 1982 .

"Ideologia e Educação". São Paulo, Cortez,

1980.

- CONSTITUIÇAOO dA REPUBLICA FEDERATIVA dO BRASil - Emendas Cons titucionais até 8 , de 14 de abril de 1977, Brasīlia, 1977. de 1988, Brasilia, 1988 .

- COORdENADORIA DE ESTUdOS E NORMAS PEDAGOGICAS. "Proposta para o ensino de geografia" - proposta preliminar para dis cussão. 2a versão, Equipe Técnica, assessoria: OLIVEIRA, Ariovaldo U. de, e LENCIONI, Sandra (USP), São Paulo, 1986.

- CORTES, Maria Rita M.S. de - "Lida e vida do menor: Um estudo do trabalhador menor no espaço urbano de Araraquara". 
São Paulo, Tese de Doutorado, USP, 1986 (mimeografado).

- DEMARTINI, Zeila B.F. - "A Educação e o Trabalho infanto-juvenil nas familias de agricultores paulistas". CERU, São Paulo, s.d. (mimeografado).

- ECO, Umberto - "Como se faz uma tese", 2 a ed., São Paulo, Perspectiva, 1985 .

- ENGELS, Friedrich - "Do Socialismo Utópico ao Socialismo Cien tîfico". Lisboa, trad. Ed. Avante, 1975.

- FERnANDES, Florestan - "0 Educador", In: Revista de Educação da APOESP, nọ 1, São Paulo, dez. 1985.

- FREIRE, Paulo - "Pedagogia do Oprimido", 9a ed. Rio de Ja neiro, Paz e Terra, 1981.

"A importância do a to de ler", 8 a ed. São Pau 10, Cortez, 1984 .

"Paulo Freire \& Educadores de Rua" . 2 a ed., Rio de Janeiro, UNICEF/SAS/FUNABEM, Lidador, 1987.

- FROMER, Ana - "Qualidade do ensino é esquecida". In: Folha de São Paulo, 06.11 .1988$, pāg. 8.

- FUndaçá IBge - Pesquisa Nacional por Amostra de Domicillio. São Paulo, 1983, Rio de Janeiro, FIBGE.

Pesquisa Nacional por Amostra de Domicillio. São Paulo, 1987, Rio de Janeiro, FIBGE. 
- FULKUI, Lia Freitas e alii - "Escolarização e sociedade: um estudo dós excluĩdos da escola", CERU - Cadernos 14, São Paulo, dez. 1981 .

"A desescolarização, trabalho infantil e a questão do menor, um projeto de pesquisa", CERU - Cadernos 15, São Paulo, agosto 1981 .

"A questão do trabalho infantil na grande im prensa paulista na década de 70". São Paulo, 1981 (mimeografado).

- FURTAdo, Celso - "Formação Econōmica do Brasill", 12a ed. São Paulo, Nacional, 1974 .

- GADOTTI, Moacir - "A Educação e Poder" Introdução à Pedagogia do conflito, 5. ed. São Paulo, Cortez, 1984.

- GAJARDo, Marcela - "A pesquisa Participante na América Latina". São Paulo, Brasiliense, 1986.

- GONÇALVES, Carlos Walter P. - "Reflexões sobre Geografia e Educação: notas de um debate". São Paulo, 1985 (mimeografado).

- Gouvela, Aparecida Joly - "0 trabalho do menor: necessidade transfigurada em virtude". Cadernos de Pesquisa da FundaCarlos Chagas. São Paulo, $44,1983$.

- GRUSPUN, Haim - "Os Direitos dos Menores". São Paulo, ALMED, 1985. 
- HARVEY, David - "A Justiça Social e a Cidade". São Paulo, Hu citec, 1980 .

- HOLANDA, Sérgio B. de - "Raízes do Brasil" 5. ed. Rio de Ja neiro, Josē 01 ympio, 1969.

- IANNI, Octāvio - "Estado e Planejamento Econömico no Brasil" (1930-1970), 3. ed. Rio de Janeiro, Civilização Brasileira, 1979 .

- KONDER, Leandro - "O que é dialética" São Paulo, Brasiliense, 1981 .

- Kowarick, Lūcio \& CAMPAnÁrio, Milton - "São Paulo". São Pau 10, 1986 (mimeografado).

- LANG, Alice, B.S.G. - "Aspirações à Educação, a Ocupação e ao Exito Social". In: Cadernos CERU nọ 15. São Paulo, 1981.

- LANGENBUCH, Juergen Richard - "A Estruturação da Grande São Paulo". Rio de Janeiro, FIBGE (Tese de Doutorado), 1971.

- LEBRUN, Gerard - "Da escola e de sua destruição". In: O Estado de São Paulo, 06.10.1984, pāg. 3 .

- LEMOS, Amālia Inēs G. de - "Cotia e sua participação no conjunto da faixa periférica da Metrōpole Paulista". São Pau 10, dissertação de mestrado, USP, 1972 (mimeografado).

\section{"Um exemplo de processo de metropolização} recente na periferia da Grande São Paulo: 0 Municīpio de Itaquaquecetuba". São Paulo, tese de Doutorado, USP, 1980 (mimeografado). 
"Pesquisa participante em geografia: Uma $1 \underline{i}$ nha de ação - experiência na periferia de São Paulo (Bra si1). In: Boletim de Geografia Teorética, 16-17(31:34): 285-288, 1986-1987. (I ENCONTRO DE GEOGRAFOS DA AMERICA LA TINA) .

- LUTfi, Eutina P. \& PONTUSChKA, Nídia N. - Estudando o Perú através do livro "Bom dia para os defuntos" - exemplo de integração entre as āreas de portuguès e de geografia no ensino de 20 grau. In: Revista Orientação nọ 6, IG. São Pau10, 1985 .

- MARTINS, José de Souza - "Sobre o modo capitalista de pensar" 2.ed. São Paulo, Hucitec, 1980.

- MARX, Karl - "O Capital" 3. ed. Rio de Janeiro, Civilização Brasileira, 1980, v.1-2.

- MENDES, Renato S. da - "OS bairros da zona Norte e os bairros orientais". In: A Cidade de São Paulo. Estudos de geografia urbana. São Paulo, Nacional, 1958. v.3.

- MORA, José Ferrater - Método dialético, dicionārio de Filoso fia, Sudamericana.

- MORAES, Antonio Carlos R. - "Epistemologia e Geografia". In: Revista Orientação nọ 6. IG. São Paulo, 1985.

- MORAES, Antonio Carlos R. \& COSTA, Wanderley M. - "A valorização do Espaço - Geografia Crïtica". São Paulo, Hucitec, 1984 . 
- NADAI, Elza - "A escola pūblica contemporānea: os currículos oficiais de histōria e o ensino temātico". In: Revista Brasileira de Histōria. Sào Paulo, v.6, set $1985 / \mathrm{fev}$. 1986.

- NIDELCOFF, Maria Teresa - "Uma escola para o povo". 20. ed. São Paulo, Brasiliense, 1984 .

- OLIVEIRA, Francisco de - "O terciārio e a divisão social do trabalho". In: Edições CEBRAP no 24. São Paulo, s.d. "A produção dos homens". In: Edições CEBRAP ne 16. São Paulo, abril/maio/junho, 1976. "O Estado e o urbano no Brasil". In: Espaços e Debates n? 6. São Paulo, junho/setembro 1982.

- PETRone, Pasquale - "Povoamento e Colonização". In: Brasil a terra e o Homem. São Paulo, Nacional, 1970, v.2.

- PIERRE, George - "Os mētodos da geografia". São Paulo, Difusão Européia do Livro, 1972.

- PONTIFICIA COMISSÁO dE JUSTIÇA E PAZ dA ARQUIdioCESE de SAO PAULO - "São Paulo 1975, Crescimento e Pobreza". São Pau 10, Loyola, 1976.

- QUAINI, Massimo - "A Construção da Geografia Humana". Rio de Janeiro, Paz e Terra, 1983.

"Marxismo e Geografia". Rio de Janeiro, Paz e Terra, 1979.

- RODGERS, Gerry y STANDING, Guy - "Funcion economica de los niños en paises de bajos ingressos". In: Revista Internacio 
nal del Trabajo, v.100, nọ 2, abril/junio de 1981.

- RODRIGUES, Neidson - "Estado, Educação e Desenvolvimento Eco nōmico". São Paulo, Cortez, 1982.

- SALM, Claudio L. - "Escola e Trabalho". São Paulo, Brasilien se, 1980 .

- SANTOS, Milton - "Sociedade e Espaço: A formação social como teoria e como método". In: Boletim Paulista de Geografia. nọ 54, São Paulo, junho de 1977.

"Relações Espaço-Temporais no mundo subdesen volvido". Seleção de Textos nọ 1, AGB, Seção Regional São Paulo. São Paulo, dez. 1976.

"Desenvolvimento Econōmico e Urbanização em paises subdesenvolvidos: os dois sistemas de fluxo da eco nomia urbana e suas implicações espaciais". In: Boletim Paulista de Geografia, nọ 53, São Paulo, fev. 1977.

"Sociedade e Espaço: A formação social como teoria e como método". In: Boletim Paulista de Geografia, no 54, junho 1977 .

"Por uma Geografia Nova", São Paulo, Hucitec

EDUSP, 1978.

"A caminho de uma teoria substantiva da ur banização". In: Revista Orientação, IG, nọ 6, São Paulo, nov. 1985.

"Amērica Latina: Nova Urbanização, novo pla nejamento, IG, nọ 7, São Paulo, dez. 1986. 
- SANTOS, Jair L.F.; LEVy, Maria Stella F.; SZMRECSANyi, Tomás (organizadores) - "Dinâmica da População", São Paulo, TAQ, 1980 .

- SANTOS, Milton R. dos - "0 Trabalho Familiar: Subordinação e Transformações - 0 exemplo dos produtores de péssego de Mairinque". São Paulo, dissertação de mestrado, USP, 1986 (mimeografado).

- SEABRA, Manoel F.G. - "Os fundamentos humanos da organização do espaço geográfico". São Paulo, 1980 (mimeografado).

"Os fundamentos naturais da organização do espaço". São Paulo, 1980 (mimeografado).

\section{"Geografias". In: Revista Orientação nọ 5,}

IG. São Paulo, 1984 .

- SIlva, T.R.N. \& NOGUEIRA, M.J. - "0 Noturno é Importante, mas

... não vai bem". In: Revista Curso Noturno um desafio no

1. Fundação Carlos Chagas. São Paulo, s.d.

"Investigação sobre uma cidadã acima de qual quer suspeita". In: Revista Curso Noturno um desafio no 2 Fundação Carlos Chagas. São Paulo, s.d.

"E preciso assumir compromissos". In: Revis ta Curso Noturno um desafio no 3. Fundação Carlos Chagas. São Paulo. s.d.

- SINGER, Paul - "Força de trabalho e emprego no Brasil - 1920/ 1969". São Paulo, Edições CEBRAP, 1971. 
"Implicações econōmicas e sociais da dinâmi

ca populacional brasileira". São Paulo, Edições CEBRAP, no 20. s.d.

"A eccnomia dos serviços". São Paulo, Edições CEBRAP, no 24. S.d.

"Economia Politica do Trabalho". 3.ed.São

Paulo, Hucitec, 1979.

"Economia Politica da Urbanização". 7.ed.

São Paulo, Brasiliense, 1980.

- SPINA, Segismundo - "Normas Gerais para os trabalhos de grau" São Pauto, Atica, 1984.

- SPINDEL, Cheywa R. - "0 menor assalariado na familia e na es cola". Trabalho apresentado na mesa redonda, sobre escola ridade e trabalho infantil, no Encontro Nacional do CERU, USP. São Paulo, setembro 1983 (mimeografado).

"Espaços de Socialização e Exploração do Me nor Assalariado: Famîlia, Escola_e Empresa". São Paulo, IDESP, monografias 2. 1986.

- SPYER, Márcia - "A Geografia do Aluno Trabalhador". São Pau 10, Loyola 1986.

- Vesentini, José W. - "Ensino da Geografia e Luta de Classes" In: Revista Orientação nọ 5. IG, 1984.

"Os movimentos populacionais - As imigrações no Brasill". In: Sociedade e Espaço. São Paulo, Atica, 1985 
.184 .

"Geografia Crïtica e Ensino". In: Revista 0 rientação. nọ 6. IG, 1985.

- VIEIRA, D.T. - "Trabalho do Menor e Escolaridade". In: Revis ta - Problemas Brasileiros. Ano V, nọ 52, julho 1967. 


\section{MATERIAL CARTOGRAFICO}

- EMPLASA. "Grande São Paulo". Esquema de articulação das "Folhas de $1 / 25.000$, escala reduzida $1 / 400.000, \mathrm{~s} / \mathrm{d}$.

- EMPLASA/PMSP. "Município de São Paulo" indice de ruas, esca la $1: 20.000, s / d$.

- InSTITUTO AgRonómico. "Municīpio de São Paulo". Fotografia Aérea, escala aproximada 1:25:000, 1962.

- Ministerio da aeronautica. "Municipio de São Paulo". Foto grafia Aérea, escala aproximada 1:10.000, 1967.

- PMSP/VASP/CRUZEIRO. "Município de São Paulo", escala 1:10.000, perĩodo $1952 / 1959$.

- SECRETARIA DE ESTADO DA EDUCAÇÃo. "Grande São Paulo". Area de Jurisdição da Coordenadoria de Ensino da Grande São Paulo: Divisões regionais de ensino - Delegacias de ensi no, escala reduzida $1 / 400.000, \mathrm{~s} / \mathrm{d}$. - Municĩpio de São Paulo". Divisões ré gionais de ensino da Capital - Delegacias de ensino da Capital, escala reduzida $1 / 400.000, \mathrm{~s} / \mathrm{d}$.

- SIMIELLI, Maria Helena, DE BIASI, Mārio "Atlas Geográfico Escolar". Mapa do Brasil (Fluxo de origem da população analisada - adaptado), São Paulo, 1984.

- VASP/CRUZEIRO/PROSPEC/GEOFOTO/AEROMAPA. "Grande São Paulo", escala aproximada 1:8.000, 1973 . 


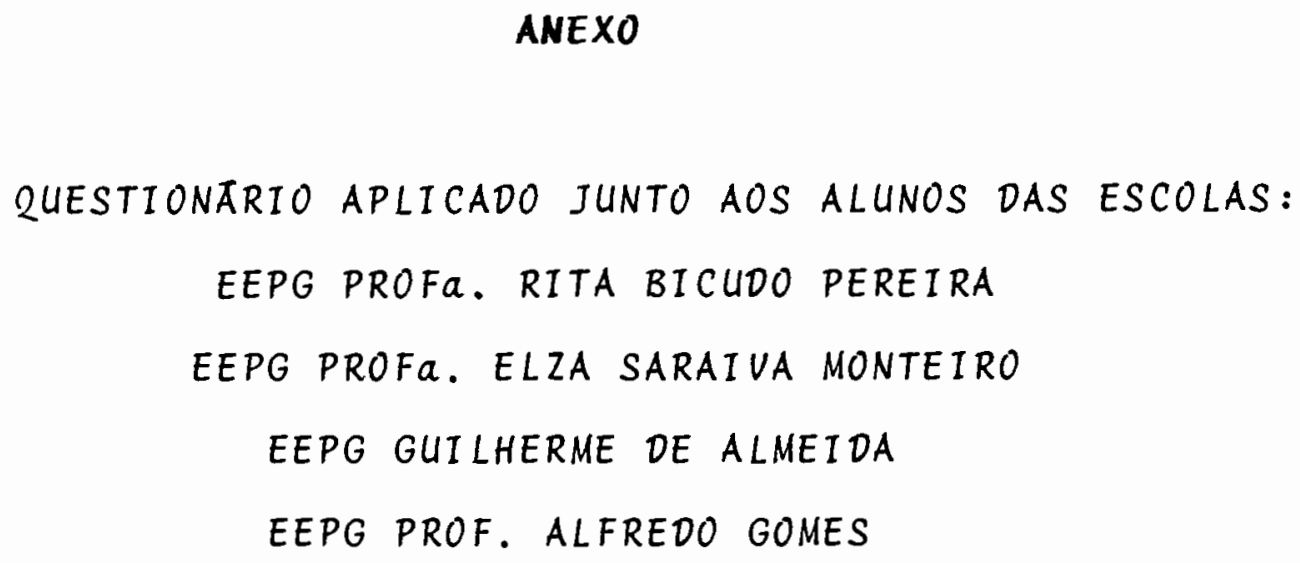


QUESTIONARIO DESTINADO AOS ALUNOS DO 10 GRAU MUNICIPIO DE SAO PAULO

E E P G

(1) Nome do Aluno

Endereço:

\section{DEPARTAMENTO DE GEOGRAFIA}

F F L C H USP

\begin{tabular}{|c|c|c|c|c|c|c|c|c|c|c|}
\hline Est. & ivil & & & & Iocal de Nascimento & & & Tha & Ocunacão & Salārio \\
\hline $\mathrm{S}$ & C & M & $\mathrm{F}$ & Idade & Município - Estado & Escolaridade & Sim & Não & Trabalho & (Atual Cr\$) \\
\hline & & & & & & & & & & \\
\hline & & & & & & & & & & \\
\hline
\end{tabular}

(2) DADOS PESSOAIS (FAMILIA) - AVOS - PAIS - IRMAOS

\begin{tabular}{|c|c|c|c|c|c|c|c|c|c|}
\hline$N O M E$ & $\begin{array}{l}\text { Relação } \\
\text { Parent. }\end{array}$ & Sexo & Idade & Escolaridade & $\begin{array}{l}\text { Local Nasc. } \\
\text { Munic. Est. }\end{array}$ & $\begin{array}{l}\text { Tempo } \\
\text { Moradia }\end{array}$ & $\begin{array}{l}\text { De onde veio } \\
\mathrm{p} / \mathrm{SP} \text { - quando }\end{array}$ & $\begin{array}{l}\text { Ocupação } \\
\text { Trabalho }\end{array}$ & $\begin{array}{l}\text { Salārio } \\
\text { Atual Cr\$ }\end{array}$ \\
\hline & & & & & & & & & \\
\hline & & & & & & & & & \\
\hline & & & & & & & & & \\
\hline & & & & & & & & & \\
\hline & & & & & & & & & \\
\hline & & & & & & & & & \\
\hline & & & & & & & & & \\
\hline & & & & & & & & & \\
\hline & & & & & & & & & \\
\hline
\end{tabular}


(3) - RELACOES DE TRABALHO - (aluno)

- Quando começou trabalhar: ano: com que idade en qual atividade trabalhou atividade atual

= Você tem registro em carteira ? $\operatorname{sim}($ ) não ( )

- Forma de Pagamento: Diarista ( ) Mensalista ( ) Outros ( )

- Quantas horas trabalhe por dia ?

- Pretende mudar de Profissão ? $\operatorname{sim}($ ) não ( )

- Para qual ? Por que ?

- Seu ordenado entra na Renda Familiar ? Descreva: De que forma?

(4) - RELACOES COM A FAMILIA

- Quantas pessoas fazem parte de sua familia ? casa ? Quantas delas Trabalham? e quantas moram na quais

- Qual a renda familiar ?

(j) - RELACOES ALUNO - ESCOLA - TRABALHO

- Para você o que é mais importante: o trabalho ou o estudo ? Explique:

- Qual a distância de sua casa ao local de trabalho? e de sua casa à escola ?

- Forma de locomoção (transporte) atē o trabalho até a escola quantas :

- Você costuma frequentar a escola fora do horärio de aula ? quando?

- O que você mais gosta da escola ?

Obs: 
A digitalização deste documento foi possível graças ao investimento do Programa de Pós-graduação em Geografia Humana (PPGH-FFLCH-USP) e realizada com recursos da Coordenação de Aperfeiçoamento de Pessoal de Nível Superior - Brasil (CAPES) - Código de Financiamento 001. Essa ação integra as atividades de comemoração dos 50 anos do PPGH no ano de 2021. Para mais informações sobre o PPGH e sua história, visite a página do programa: http://ppgh.fflch.usp.br/.

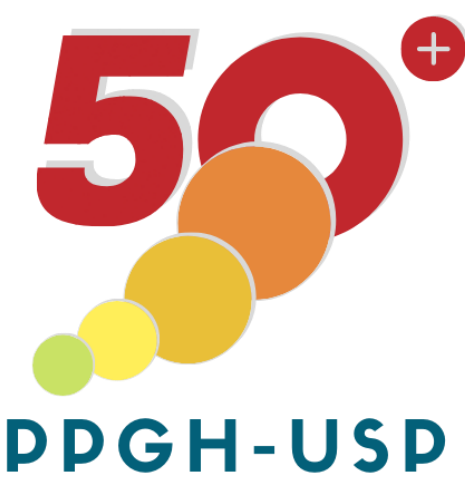

$1971-2021$ 